\title{
Laparoscopic surgical treatment for ulcerative colitis
}

Ph.D. Thesis

JÁNOS TAJTI M.D.

Supervisor: György Lázár M.D., Ph.D., D.Sc.

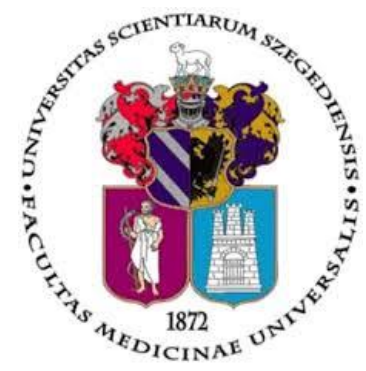

Department of Surgery

Faculty of Medicine

University of Szeged

Szeged

2019 


\section{CONTENTS}

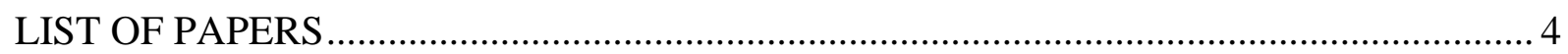

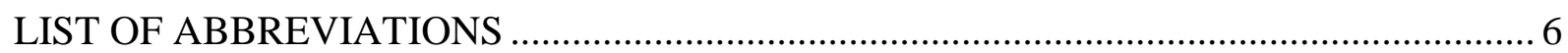

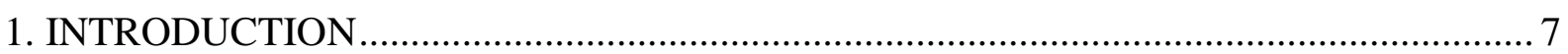

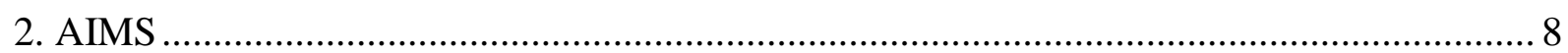

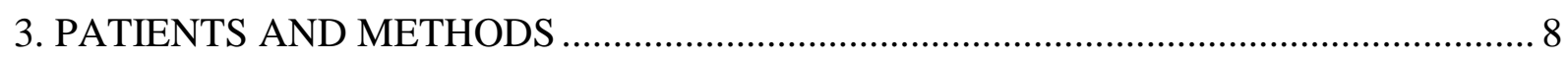

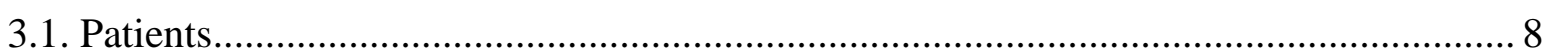

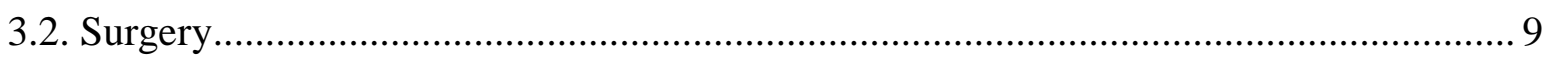

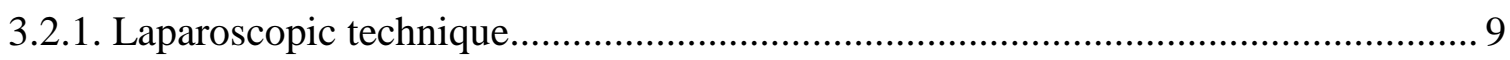

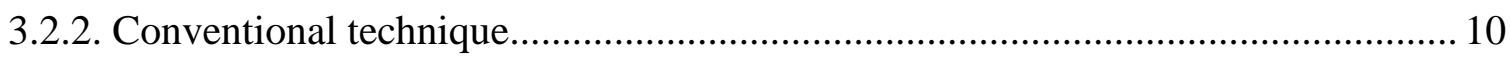

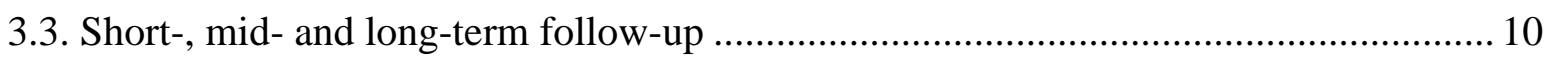

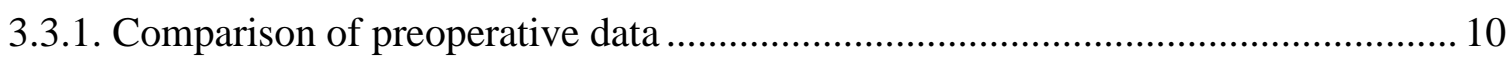

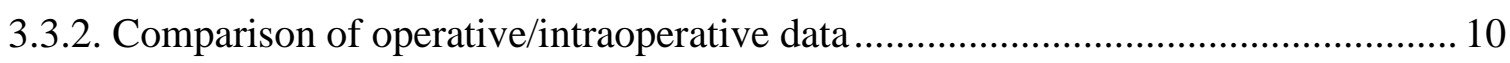

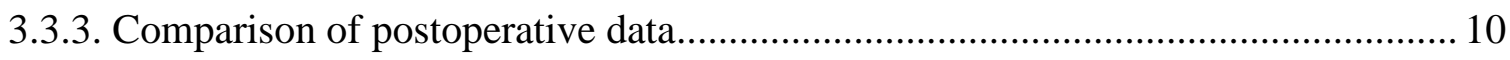

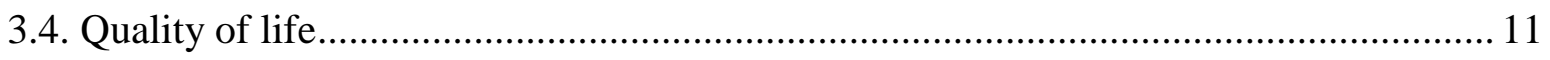

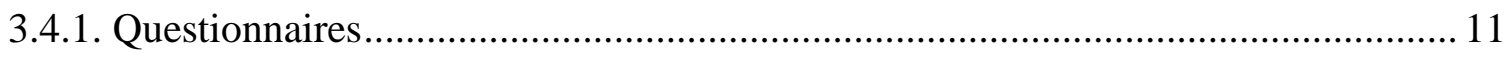

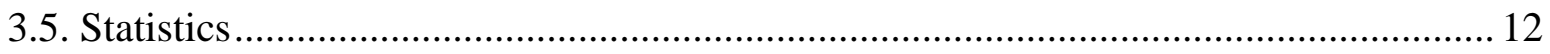

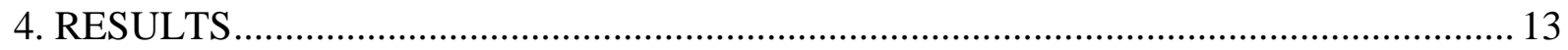

4.1. Comparison of the conventional and the minimally invasive surgical method in

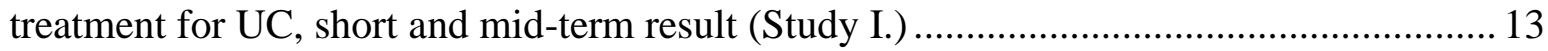

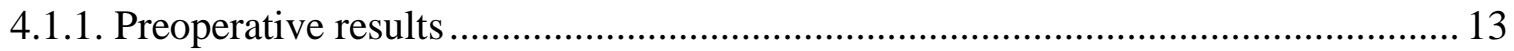

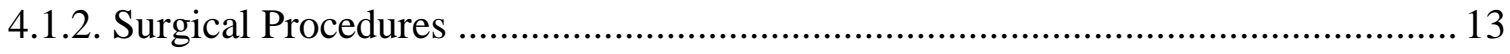

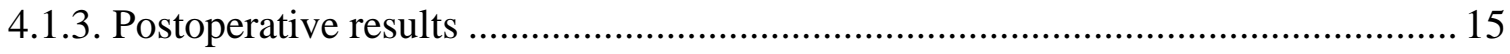

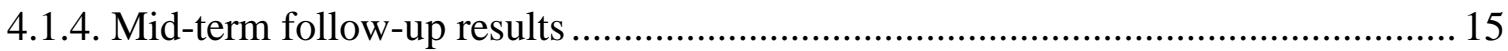

4.2. Comparison of the conventional and the minimally invasive surgical method in treatment for UC, long-term results (Study II.) ........................................................ 18

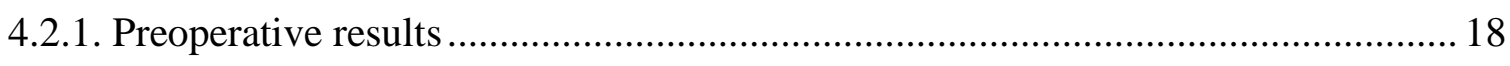

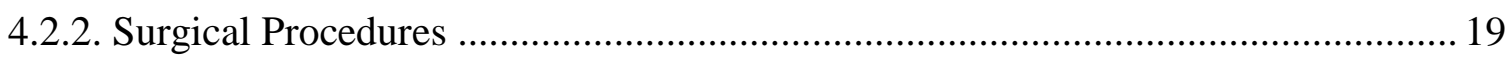

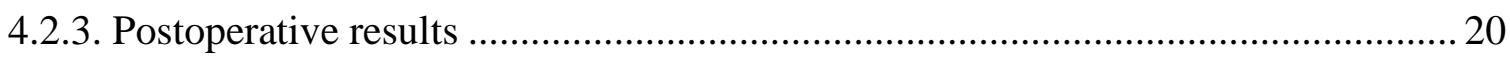

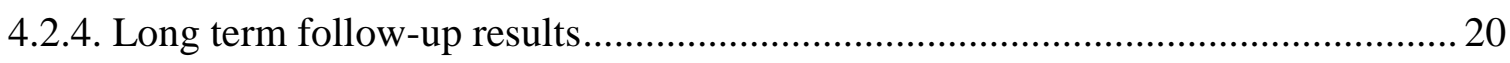

4.3. Evaluate quality of life after surgery for UC by investigating the connection between gastroenterological and psychological conditions, daily activities (Study III.) ................... 21

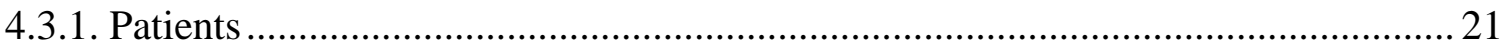

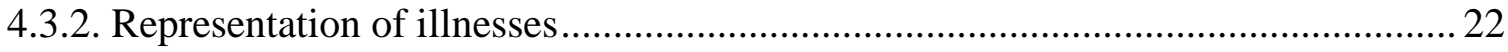

4.3.3. Psychological consequences of having a stoma.................................................. 22 


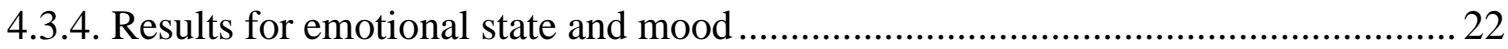

4.3.5. Comparing laparoscopy and open surgery …..................................................... 23

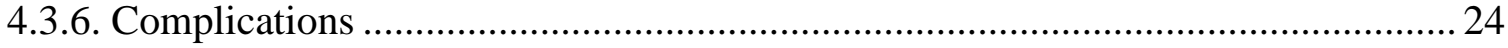

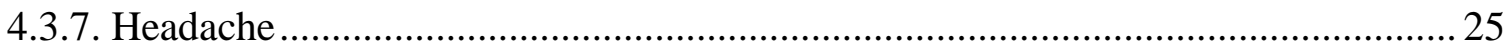

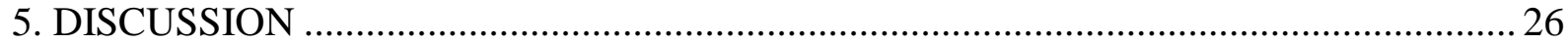

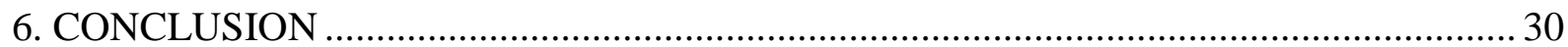

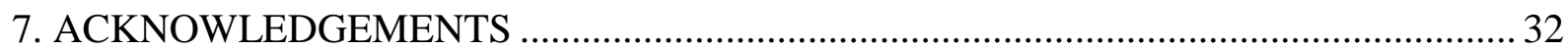

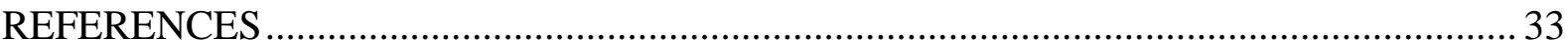




\section{LIST OF PAPERS}

\section{This doctoral thesis is based on the following publications:}

I. Tajti J Jr, Simonka Z, Paszt A, Abraham S, Farkas K, Szepes Z, Molnar T, Nagy F, Lazar G. Role of laparoscopic surgery in the treatment of ulcerative colitis; short- and mid-term results. Scand J Gastroenterol. 2015; 50: 406-412. IF: 2.199

II. Tajti J Jr, Simonka Zs, Paszt A, Ábrahám Sz, Farkas K, Szepes Z, Molnár T, Nagy F, Lázár Gy. [Minimally invasive surgical treatment of ulcerative colitis - long-term results] [Article in Hungarian] Orv Hetil. 2015; 156(39): 1585-1592. IF: 0.291

III. Tajti J Jr., Látos M, Farkas K, Ábrahám S, Simonka Z, Paszt A, Molnár T, Lázár G. Effect of Laparoscopic Surgery on Quality of Life in Ulcerative Colitis. J Laparoendosc Adv Surg Tech A. 2018; 28(7):833-838. IF (2017): 1.257

IV. Tajti Jr. J, Látos M, Ábrahám Sz, Simonka Zs, Paszt A, Lázár Gy. [Tension-Type Headache In Ulcerative Colitis]. [Article in Hungarian] Ideggyogy Sz 2017; 70(11-12):389393. IF (2016): 0.322

Total impact factor of original papers directly related to the thesis: 4.069

\section{Publications not directly related to the thesis:}

I. Simonka Zs, Paszt A, Ábrahám Sz, Pieler J, Tajti J, Tiszlavicz L, Németh I, Izbéki F, Rosztóczy A, Wittmann T, Rárosi F, Lázár Gy. The effects of laparoscopic Nissen fundoplication on Barrett's esophagus: Long-term results. Scand J Gastroenterol. 2012; 47: 13-21. IF : 2.156

II. Tajti J Jr, Pieler J, Simonka Z, Paszt A, Lázár G. [Treatment of pregnancy-associated breast cancer]. [Article in Hungarian] Magy Seb. 2014; 67(4): 268-70.

III. Simonka Z, Paszt A, Géczi T, Ábrahám S, Tóth I, Horváth Z, Pieler J, Tajti J, Varga A, Tiszlavicz L, Németh I, Izbéki F, Rosztóczy A, Wittmann T, Lázár G. [Comparison of surgical patients with gastroesophageal reflux disease and Barrett's esophagus] [Article in Hungarian] Magy Seb. 2014; 67(5): 287-296. 
IV. Farkas K, Saródi Z, Bálint A, Földesi I, Tiszlavicz L, Szücs M, Nyári T, Tajti J, Nagy F, Szepes Z, Bor R, Annaházi A, Róka R, Molnár T. The diagnostic value of a new fecal marker, matrix metalloprotease-9, in different types of inflammatory bowel diseases. J Crohns Colitis. 2015; 9(3): 231-7. IF: 6.585

Cumulative impact factor: 12.81 


\section{LIST OF ABBREVIATIONS}

$\begin{array}{ll}\text { ASA } & \text { Anesthesiologists Physical Status } \\ \text { BIPQ } & \text { Brief Illness Perception Questionnaire } \\ \text { BMI } & \text { Body Mass Index } \\ \text { GIQLI } & \text { C-Reactive Protein } \\ \text { Hgb } & \text { Hemoglobin } \\ \text { Htc } & \text { Hematocrit } \\ \text { ICU } & \text { Intensive Care Unit } \\ \text { IBD } & \text { Inflammatory Bowel Diseases } \\ \text { IPAA } & \text { Ileal Pouch-Anal Anastomosis } \\ \text { MRSA } & \text { Methicillin-resistant Staphylococcus aureus } \\ \text { SIBDQ } & \text { Short Inflammatory Bowel Disease Questionnaire } \\ \text { UC } & \text { Ulcerative Colitis } \\ \text { WBC } & \text { White Blood Cell }\end{array}$




\section{INTRODUCTION}

Ulcerative colitis (UC) is a chronic inflammatory disease affecting the whole large intestine. The epidemiological data reveal that the incidence of UC is constantly rising, primarily as a consequence of the spreading of the "western" lifestyle and urbanization ${ }^{[1]}$. The incidence of inflammatory bowel diseases (IBD) is 11.3/100,000 in Eastern Europe, 14.0/100,000 in Western Europe, and it is estimated to be $24 / 100,000$ in Hungary ${ }^{[2]}$. In 2010, the IBD registry of five Hungarian centres included 1390 patients, 539 of whom had UC, but since the estimated prevalence of IBD in Hungary is 25,000 , these data relate only to the more severe cases ${ }^{[3]}$. The two varieties of IBD are UC and Crohn's disease. Crohn's disease affects the entire gastrointestinal tract, while UC affects the colon and rectum. The exact pathogenesis of IBD is still unknown, but environmental, genetic and immunological impacts and interactions are postulated ${ }^{[1,4]}$. UC is characterized by inflammation and ulcers of the colon and rectum, and destruction of the intestinal wall, which appear firstly in the recto-sigmoid colon. Thanks to the broad-spectrum medical and biological therapy, the disease can generally be controlled for a long time with conservative treatment, but unresponsive cases with frequent relapses and complicated cases require surgical intervention. An estimated $25-45 \%$ of patients with UC need surgery at some time ${ }^{[1,5,6]}$. The purpose of the surgical intervention is to remove the affected bowel segment, which can be achieved with either the conventional, open or the laparoscopic technique. The first minimally invasive colon resection, a right hemicolectomy was performed by Moise Jacobs in $199{ }^{\text {[7] }}$. Currently, the generally accepted procedure, which has become the gold standard for the surgical treatment of UC, is total proctocolectomy with the creation of an ileal pouch-anal anastomosis (IPAA) ${ }^{[8,9]}$. This procedure was first performed with a laparoscopic approach by Peters in $1992^{[10]}$. A number of studies have shown that laparoscopic surgery has numerous advantages, such as less postoperative pain, shorter hospital stay, less time required for recovery of the bowel function, and better cosmetic results ${ }^{[11]}$. The importance of surgical treatment is supported by studies that show that patients treated with conservative methods experienced a worse long-term quality of life compared to those receiving surgical treatment ${ }^{[12,13]}$. As a result, it can be concluded that surgery provides successful treatment for UC in the long term and it is therefore important to inform the patients about it. Rather limited experience is available, however, as regards the long-term results of laparoscopic surgery. Limited data are available on quality of life in patients with UC undergoing surgery as well. Laparoscopic technique for the surgical 
intervention of UC was initiated in the Department of Surgery, University of Szeged in 2005, since then our working group gained the greatest experience in this field in Hungary.

\section{AIMS}

(i) Compare the short- and mid-term follow-up results on patients treated for UC with the conventional and the minimally invasive surgical method (Study I.).

(ii) Compare the long-term follow-up results on patients treated for UC with the conventional and the minimally invasive surgical method (Study II.).

(iii) Evaluate quality of life after surgery for UC by investigating the connection between gastroenterological and psychological conditions, daily activities (Study III.).

\section{PATIENTS AND METHODS}

\subsection{Patients}

Patients who had undergone operation for UC between 1 January 2005 and 1 March 2016 were involved in our investigation.

Study I. The first follow-up period - from 1 January 2005 to 31 May 2013, mean follow-up of 38 (1-92) months - was defined as short- and mid-term follow-up, with a total of 45 patients ( $n=27$ women, $n=18$ men). The mean age of the patients was $42.29 \pm 14.37$ years in the laparoscopy group and $38.91 \pm 12.58$ years in the open surgery group.

Study II. The second period - from 1 January 2005 to 31 December 2014, mean follow-up of 47,84 (3-111) months - was defined as long-term follow-up, with 56 patients ( $\mathrm{n}=31$ women, $\mathrm{n}=25$ men). The mean age of the patients was $45.09 \pm 14.49$ years in the laparoscopy group and $38.26 \pm 12.68$ years in the open surgery group.

Study III. At the third period between 1 January 2005 and 1 March 2016, surgery was performed for UC in a total of 75 patients. The mean duration of the follow-up was 46 (1-124) months. Our examinations were performed in 58 cases ( $n=29$ women, $n=29$ men). The mean age of the patients was $46.98 \pm 13.38$ years in the laparoscopy group and $45.47 \pm 12.59$ years in the open surgery group. 


\subsection{Surgery}

Strategy for the surgical treatment of UC is determined by the general status of the patients and the type of the surgical indication.

The indication for emergency surgery was the presence of a severe, toxic condition, which was accompanied by bleeding, perforation or severe malnutrition. In case of emergency surgical indication or patients with weak general status three-stage surgical strategy $(i$. total colectomy, mucous fistula and end ileostomy, ii. J-pouch creation and ileostomy, iii. ileostomy closure) was needed.

The elective interventions were performed because of a condition that could not be controlled with conservative treatment. In an elective case patients with good general status were undergone a two-stage surgical procedure (i. proctocolectomy, IPAA and ileostomy, ii. closure of ileostomy).

During our practice one-stage surgical procedures (rectum extirpation, proctocolectomy with end ileostomy, colectomy with ileorectostomy, total colectomy with ileostomy) were also performed, because of sphincter disorder.

Conversion from laparoscopy to open surgery was required, because of massive adhesions or because of the risk of bowel injury and perforation. These cases were excluded from the subsequent analyses.

All surgical procedures were carried out in general anaesthesia combined with epidural analgesia. During the procedures we used metronidazole and 2nd generation cephalosporin for antibiotic prophylaxis, while during emergency operations therapy was completed with 3rd generation cephalosporin or imipenem/cilastatin in cases of severe septico-toxic condition or peritonitis.

\subsubsection{Laparoscopic technique}

The laparoscopically assisted proctocolectomy + IPAA and the total colectomy + mucous fistula were performed with the use of 6 or 7 ports, depending on the auxiliary incision. The resection of the colon, and the creation of the anastomosis and the mucous fistula were performed from the cosmetically favourable Pfannenstiel incision. The J-pouch was created from the terminal ileum with a straight stapler(s), and a double stapler technique was used for the ileoanal anastomosis. The staple line was protected with a loop ileostomy in every case. 
The pouch created as the second surgical step was also achieved from the Pfannenstiel incision.

\subsubsection{Conventional technique}

In the cases involving the conventional method, a midline laparotomy was performed to explore the abdominal cavity, in the lower recess of which the mucous fistula was created; the pouch and the ileoanal anastomosis were created in the same way as during the laparoscopic interventions.

\subsection{Short-, mid- and long-term follow-up}

\subsubsection{Comparison of preoperative data}

During the preoperative period general status of UC patients was examined, namely gender, Body Mass Index (BMI), Anesthesiologists physical status (ASA) class, age, inflammatory parameters, blood count, albumin level, number of stools daily. The time from the onset of UC to surgery, the use of biological therapy was described.

\subsubsection{Comparison of operative/intraoperative data}

Distribution and duration of the different types of surgical interventions were examined.

\subsubsection{Comparison of postoperative data}

The length of hospital stay, the number of days spent in the intensive care unit (ICU), the time to the recovery of the bowel function, and the need for transfusion were examined. Postoperative complications were classified as early (within 30 days) or late (after 30 days) with regard to their onset after primary surgery. Complications requiring and not requiring reoperation were investigated. From the aspect of the cosmetic result, the patients graded their satisfaction on a five-item scale (not at all satisfied - slightly satisfied- moderately satisfied rather satisfied - very satisfied). The preoperative and postoperative general status of the patients were graded on a scale from 1 to 10 , where 1 was the best, and 10 was the worst general status. Postoperative number of stools daily and body weight were registered and compared. 


\subsection{Quality of life}

Quality of life was examined with questionnaires considering gastroenterological and psychological conditions, daily activities and headache. Results were analyzed in the laparoscopic group and in patients undergoing open surgery, in patient with or without a stoma, in case of acute and elective interventions, and regarding early and late complications.

\subsubsection{Questionnaires}

\subsubsection{Testing gastroenterological conditions}

\subsection{Functional Scoring System}

The functional scoring system is a questionnaire consisting of twelve questions on patients' bowel movements (number of bowel movements during the day and at night, urgency and perianal soreness), incontinence (during the day and at night and use of protective pads), diet, drug therapy and potential social disadvantages ${ }^{[14]}$.

\subsection{Gastrointestinal Quality of Life Index (GIQLI)}

The GIQLI studies gastroenterological condition (abdominal pain, epigastric fullness, bloating, flatulence, eructation, increased bowel movements, urgency, diarrhoea, constipation, nausea, blood in the stool, heartburn and bowel incontinence), alimentation (appetite, eating speed and swallowing a bite), physical condition, daily activities, social activities and psychological condition for two weeks before completing the questionnaire ${ }^{[15]}$.

\subsection{Short Inflammatory Bowel Disease Questionnaire (SIBDQ)}

The SIBDQ studies gastrointestinal symptoms and their effect on social and physical wellbeing for two weeks before completing the questionnaire based on ten questions ${ }^{[16]}$.

\subsubsection{Considering psychological status}

\subsection{Spielberger's State-Trait Anxiety Questionnaire and the Beck Depression Inventory}

Spielberger's State-Trait Anxiety Questionnaire and the Beck Depression Inventory were used to measure the level of anxiety and mood ${ }^{[17,18]}$. 


\subsection{Brief Illness Perception Questionnaire (BIPQ)}

Illness perceptions and attitude towards healing were studied using the BIPQ, consisting of eight subscales (consequences, timeline, personal control, treatment control, identity, concern, coherence and emotional representation) ${ }^{[19]}$.

\subsubsection{Examining headache}

\subsection{Headache Questionnaire}

The nature of the headache was evaluated with the 16-question Headache Questionnaire. It contains questions about frequency of headaches, laterality, localization, nature, severity, duration, accompanying symptoms, patients' opinions on the headache, therapy employed, efficacy of therapy and the effect of the headache on everyday life, based on the criteria of the International Classification of Headache Disorders, $3^{\text {rd }}$ edition (beta version) ${ }^{[20]}$.

\subsection{Statistics}

Patients were examined retrospectively, and statistical analysis was performed with the SPSS program (IBM SPSS Statistics, Version 20.0 2014, Chicago, IL, USA). Pearson and Spearman correlations were used to determine relationships between variables. The independent samples t-test, Mann-Whitney test, ANOVA and Chi-square test were used to compare the groups. Values were considered to be statistically significant if $P$ was lower than 0.05 . 


\section{RESULTS}

\subsection{Comparison of the conventional and the minimally invasive surgical method in treatment for UC, short- and mid-term result (Study I.)}

\subsubsection{Preoperative results}

There was no significant difference in the time from the onset of UC to surgery between the laparoscopic group (8.71 years) and the open surgery group (8.63 years). In the preoperative period, 16 patients $(35.55 \%)$ received biological therapy, with infliximab. The preoperative laboratory test results, revealed a significant difference between the two groups only in CRP (Table 1).

\begin{tabular}{|c|c|c|c|c|c|c|c|c|}
\hline & $\begin{array}{l}\text { Age } \\
\text { (years) }\end{array}$ & ASA & BMI & $\begin{array}{l}\text { WBC } \\
(\mathrm{G} / \mathrm{L})\end{array}$ & $\begin{array}{l}\text { CRP } \\
(\mathrm{mg} / \mathrm{L})\end{array}$ & $\begin{array}{l}\mathrm{Hgb} \\
(\mathrm{g} / \mathrm{L})\end{array}$ & $\begin{array}{l}\mathrm{Htc} \\
(\mathrm{L} / \mathrm{L})\end{array}$ & $\begin{array}{l}\text { Albumin } \\
(\mathrm{g} / \mathrm{L})\end{array}$ \\
\hline Laparoscopy & 41.29 & 2.19 & 24.03 & 8.33 & 16.79 & 105.43 & 33.81 & 37.79 \\
\hline \multirow[t]{2}{*}{ Open surgery } & 38.91 & 2.14 & 22.88 & 9.06 & 47.66 & 109.13 & 33.96 & 33.01 \\
\hline & & $P=0.818$ & $P=0.490$ & $P=0.529$ & $* P=0.028$ & $P=0.471$ & $P=0.920$ & $P=0.108$ \\
\hline
\end{tabular}

Table 1. Mean age, American Society of Anesthesiologists physical status (ASA) class, Body Mass Index (BMI) and preoperative laboratory data in the laparoscopic and open surgery groups. $* P \leq 0.05$

WBC: White Blood Cell; CRP: C-Reactive Protein; Hgb: Hemoglobin; Htc: Hematocrit

On the other hand, the preoperative laboratory data for the patients who participated in emergency surgery indicated an increased inflammatory response. The hematocrit levels (31.31 vs. $35.31 \mathrm{~L} / \mathrm{L}, P=0.007)$ and albumin levels (28.93 vs. $39.67 \mathrm{~g} / \mathrm{L}, P<0.001)$ were significantly lower in the emergency group than in the elective group.

Before the surgical interventions, the mean number of stools daily was 10.78 and 9.64 , respectively, in the two groups. The last colonoscopy report before surgery indicated 30 cases $(66.67 \%)$ of pancolitis, 5 cases $(11.11 \%)$ of left-sided involvement and 10 cases $(22.22 \%)$ of distal involvement.

\subsubsection{Surgical Procedures}

Sixteen $(35.5 \%)$ of the surgical interventions were emergency procedures, while $29(64.5 \%)$ were elective interventions. The laparoscopic technique was used in $23(51.1 \%)$ and the conventional method in $22(48.9 \%)$ cases. Total proctocolectomy with the creation of a J- 
pouch and protective loop ileostomy was carried out laparoscopically in 13 cases and with the open technique in 5 cases. Total colectomy with mucous fistula and end ileostomy was performed using the minimally invasive technique in 8 cases and the conventional method in 13 cases. Conversion from laparoscopy to open surgery was required in 3 cases $(3 / 26$, $11.53 \%$ ), because of massive adhesions during elective surgery (1 case) or because of the risk of bowel injury and perforation during emergency surgery (2 cases). These cases were excluded from the subsequent analyses. The distribution of the various surgical procedure is presented in Table 2.

\begin{tabular}{llll}
\hline & & $\begin{array}{l}\text { Laparoscopy } \\
(\mathrm{n}=23)\end{array}$ & $\begin{array}{l}\text { Open surgery } \\
(\mathrm{n}=22)\end{array}$ \\
\hline Two-stage surgery & $\begin{array}{l}\text { i. Proctocolectomy, J-pouch, } \\
\text { ileostomy }\end{array}$ & $13(56.5 \%)$ & $5(23 \%)$ \\
& $\begin{array}{l}\text { ii. Ileostomy closure } \\
\text { Three-stage surgery }\end{array}$ & 11 & 4 \\
& $\begin{array}{l}\text { i. Total colectomy, mucous } \\
\text { fistula, end ileostomy }\end{array}$ & $8(34.8 \%)$ & $13(59 \%)$ \\
& $\begin{array}{l}\text { ii. J-pouch creation, ileostomy } \\
\text { iii. Ileostomy closure }\end{array}$ & 6 & 12 \\
& $\begin{array}{l}\text { Rectum extirpation } \\
\text { One-stage surgery }\end{array}$ & $2(8.7 \%)$ & 0 \\
& $\begin{array}{l}\text { Proctocolectomy, end ileostomy } \\
\text { Colectomy, ileorectostomy }\end{array}$ & 0 & $2(9 \%)$ \\
& Total colectomy, ileostomy & 0 & $1(4.5 \%)$ \\
\hline
\end{tabular}

Table 2. Distribution of surgery

From the aspect of the duration of surgery, the open method was found to be significantly shorter than the laparoscopic intervention (Table 3).

\begin{tabular}{llll}
\hline & Laparoscopy & Open surgery & \\
\hline $\begin{array}{l}\text { Proctocolectomy, J-pouch, } \\
\text { ileostomy }\end{array}$ & 245.42 & 185 & $* P=0.040$ \\
$\begin{array}{l}\text { Total colectomy, mucous fistula, } \\
\text { end ileostomy }\end{array}$ & 187 & 151.67 & $* P=0.012$ \\
\hline
\end{tabular}

Table 3. Distribution of duration of surgery (minutes) $* P \leq 0.05$ 


\subsubsection{Postoperative results}

There was no death in the perioperative period in either group. There was no significant difference between immediate postoperative results (Table 4).

\begin{tabular}{llll}
\hline & Laparoscopy $(\mathrm{n}=23)$ & Open surgery $(\mathrm{n}=22)$ & \\
\hline Hospital stay (days) & 11.50 & 11.63 & $P=0.914$ \\
$\begin{array}{l}\text { Time to recovery of } \\
\text { bowel function (days) }\end{array}$ & 1.44 & 1.55 & $P=0.656$ \\
$\begin{array}{l}\text { Time spent in the ICU } \\
\text { (days) }\end{array}$ & 2.50 & 2.09 & $P=0.437$ \\
$\begin{array}{l}\text { Need for blood } \\
\text { transfusion (units) }\end{array}$ & 2.05 & 3.13 & $P=0.57$ \\
\hline
\end{tabular}

Table 4. Immediate postoperative results in the laparoscopic and open surgery groups

There was no difference $(P=0.945)$ between the laparoscopic group and the open surgery group in the rate of early complications requiring or not requiring reoperation, which are listed in Table 5.

\begin{tabular}{|c|c|c|c|}
\hline & Laparoscopy $(\mathrm{n}=23)$ & Open surgery $(n=22)$ & \\
\hline $\begin{array}{l}\text { Requiring } \\
\text { reoperation }\end{array}$ & $\begin{array}{l}\text { - Ileus (2) } \\
\text { - Abdominal wall } \\
\text { disruption in the area of } \\
\text { the mucous fistula (1) } \\
\text { - Stoma repair (1) }\end{array}$ & $\begin{array}{l}\text { - Ileus (3) } \\
\text { - Septic condition (1) }\end{array}$ & \\
\hline Total & $17.4 \%(4 / 23)$ & $18 \%(4 / 22)$ & $P=0.945$ \\
\hline $\begin{array}{l}\text { Not requiring } \\
\text { reoperation }\end{array}$ & - Subileus (3) & $\begin{array}{l}\text { - Subileus (1) } \\
\text { - Anal bleeding (1) } \\
\text { - Dehydration (1) } \\
\text { - Hydrothorax (1) } \\
\text { - Urination problems (1) }\end{array}$ & \\
\hline Total & $13 \%(3 / 23)$ & $22 \%(5 / 22)$ & $P=0.396$ \\
\hline
\end{tabular}

Table 5. Early postoperative complications (within 30 days) during the short- and midterm follow up

\subsubsection{Mid-term follow-up results}

During the follow-up period, wound infection was detected in 8 patients (34.8\% of the cases) in the laparoscopic group, and in 7 patients (31.8\% of the cases) in the open surgery group; 
from this respect, there was no significant difference between the groups $(P=0.833)$. Methicillin-resistant Staphylococcus aureus (MRSA) infection was confirmed in 2 patients and 1 patient, respectively. During the mean follow-up of 36 months, significantly fewer complications, involving intestinal obstruction, septic condition, anastomotic stenosis, anal bleeding and pouch-vaginal fistula formation, occurred in the laparoscopic group (Table 6).

\begin{tabular}{|c|c|c|c|}
\hline & Laparoscopy $(\mathrm{n}=23)$ & Open surgery $(n=22)$ & \\
\hline Septic condition & 0 & $\begin{array}{l}\text { - Severe pouchitis (1) } \\
\text { - Perianal abscess (4) } \\
\text { - Lesser pelvic abscess (1) }\end{array}$ & \\
\hline Total & $0 \%(0 / 23)$ & $27 \%(6 / 22)$ & $* * P=0.007$ \\
\hline \multicolumn{4}{|l|}{ Intestinal obstruction } \\
\hline $\begin{array}{l}\text { - requiring surgical } \\
\text { intervention }\end{array}$ & - Ileus (1) & - Ileus (4) & \\
\hline $\begin{array}{l}\text { - not requiring surgical } \\
\text { intervention }\end{array}$ & - Subileus (1) & - Subileus (6) & \\
\hline Total & $8.7 \%(2 / 23)$ & $45 \%(10 / 22)$ & $* * P=0.005$ \\
\hline Postoperative hernia & $\begin{array}{l}\text { - In the ileostomy scar } \\
\text { (2) }\end{array}$ & $\begin{array}{l}\text { - In the midline laparotomy } \\
\text { scar (4) }\end{array}$ & \\
\hline Total & $8.7 \%(2 / 23)$ & $18 \%(4 / 22)$ & $P=0.349$ \\
\hline Other & $\begin{array}{l}\text { - Anastomotic stenosis } \\
\text { (1) }\end{array}$ & $\begin{array}{l}\text { - Anastomotic stenosis (5) } \\
\text { - Anal bleeding (2) } \\
\text { - Severe sphincter damage (1) } \\
\text { - Pouch-vaginal fistula (2) } \\
\text { - Dehydration (1) }\end{array}$ & \\
\hline Total & $4.3 \%(1 / 23)$ & $50 \%(11 / 22)$ & $* * * P=0.001$ \\
\hline
\end{tabular}

Table 6. Late postoperative complications (after 30 days) during the short- and mid-term follow up. $* * P \leq 0.01, * * * P \leq 0.001$

In the laparoscopic group, surgery was performed because of ileus in 1 case, and 1 case of subileus resolved after medical therapy. Abdominal wall reconstruction was carried out electively in 2 cases because of a hernia in the scar of the previous ileostomy. Endoscopic dilatation was performed in 1 case of anastomotic stenosis.

In the conventional surgery group, surgery was performed because of ileus as a late complication in 4 cases. Four perianal abscesses were explored, 3 of which were treated by Seton drainage. Perianal exploration was needed in 1 case because of an abscess in the lesser pelvis. In 1 patient, excision of the pouch was required because of severe pouchitis and a 
perianal abscess. Rectum extirpation was necessary in 2 patients because of an impaired sphincter function and anal bleeding. The abdominal wall was reconstructed in 4 cases because of postoperative hernia. Two anastomotic stenoses were dilated surgically, while endoscopic dilatation was performed in 3 patients. Six cases of subileus, 1 case of anal bleeding and 1 case of dehydration were resolved through conservative treatment.

During the course of the follow-up, there were significantly fewer urgent admissions to a medical unit in the laparoscopic group ( 1 vs. $6, P=0.034)$.

The clinical symptoms and endoscopic findings confirmed 15 cases of pouchitis, affecting $41 \%$ of the patients with a pouch (6 in the laparoscopic group and 9 in the open surgery group). The inflammation of the pouch was accompanied by cuffitis in 10 cases.

Of the 16 patients treated with infliximab, 4 developed an early postoperative complication.

A significant improvement in the general status (scale from 1 to 10) was measured in both groups after the surgery, but there was no significant difference between the two groups. The postoperative mean number of stools daily at the last medical check-up during the follow-up was the same in the two groups. The preoperative and current body weights indicated an increase in both groups, which was significant in the open surgery patient population (Table 7).

\begin{tabular}{lllll}
\hline & & Preoperative & Current & \\
\hline General status & Laparoscopy $(\mathrm{n}=23)$ & $8.88 \pm 1.5$ & $2.38 \pm 2.03$ & $* * * P<0.0001$ \\
& Open surgery $(\mathrm{n}=22)$ & $8.8 \pm 1.74$ & $2.6 \pm 2.03$ & $* * * P=0.001$ \\
Number of & Laparoscopy $(\mathrm{n}=23)$ & $10.78 \pm 5.80$ & $7.83 \pm 3.28$ & $P=0.061$ \\
stools daily & Open surgery $(\mathrm{n}=22)$ & $9.64 \pm 5.38$ & $7.81 \pm 3.31$ & $P=0.238$ \\
Body weight & Laparoscopy $(\mathrm{n}=23)$ & $67.61 \pm 16.19$ & $70.83 \pm 18.31$ & $P=0.554$ \\
& Open surgery $(\mathrm{n}=22)$ & $63.24 \pm 16.15$ & $73.68 \pm 12.73$ & $* P=0.030$ \\
\hline
\end{tabular}

Table 7. Pre- and postoperative general status, number of stools daily and body weight in the laparoscopic and open surgery groups. $* P \leq 0.05, * * * P \leq 0.001$

The mean length of the midline laparotomy incision in the open surgery group was $13.9 \pm 7 \mathrm{~cm}$, and the mean length of the Pfannenstiel incision in the laparoscopic group was $10.5 \pm 3.5 \mathrm{~cm}$. From the aspect of the cosmetic result, the patients graded their satisfaction on a five-item scale, which demonstrated that those who had undergone open surgery were on average "rather satisfied", while the laparoscopic patients were on average "very satisfied". 


\subsection{Comparison of the conventional and the minimally invasive surgical method in treatment for UC, long-term results (Study II.)}

\subsubsection{Preoperative results}

No difference was found between the two groups in the preoperative data. The preoperative laboratory test results (WBC count, $\mathrm{CRP}, \mathrm{Hgb}, \mathrm{Htc}$ and albumin) revealed a significant difference between the two groups in WBC count and CRP (Table 8).

\begin{tabular}{llll}
\hline & $\begin{array}{l}\text { Laparoscopy } \\
(\mathrm{n}=33)\end{array}$ & $\begin{array}{l}\text { Open surgery } \\
(\mathrm{n}=23)\end{array}$ & \\
\hline Age (years) & 45.09 & 38.26 & $P=0.074$ \\
ASA & 2.27 & 2.05 & $P=0.125$ \\
BMI & 22.76 & 22.59 & $P=0.906$ \\
Time (years) from the & 9.05 & 8.26 & \\
onset of UC to surgery & & & \\
WBC (G/L) & 8.5 & 10.42 & $* P=0.032$ \\
CRP (mg/L) & 23.29 & 51.51 & $* P=0.031$ \\
Albumin (g/L) & 37.8 & 33.46 & $P=0.096$ \\
Hgb (g/L) & 109.72 & 109.52 & $P=0.969$ \\
Htc (L/L) & 34.27 & 33.95 & $P=0.828$ \\
\hline
\end{tabular}

Table 8. Mean age, American Society of Anesthesiologists physical status (ASA) class, Body Mass Index (BMI) and preoperative laboratory data in the laparoscopic and open surgery groups. $* P \leq 0.05$

WBC: White Blood Cell; CRP: C-Reactive Protein; Hgb: Hemoglobin; Htc: Hematocrit

The preoperative laboratory data for the patients who participated in emergency surgery indicated an increased inflammatory response. In the preoperative period, 23 patients $(41.07 \%)$ received biological therapy with infliximab.

As concerns the extraintestinal manifestations of the disease, eye abnormalities were found in 5 cases $(10.7 \%)$, skin disorders in 7 patients $(12.5 \%)$, and bone and joint complaints in 18 patients $(32.14 \%)$. The possibility of primary sclerosing cholangitis arose in 3 patients $(5.3 \%)$, there were 7 cases $(12.5 \%)$ of prior deep vein thrombosis, a history of tumour disease (in the kidney or the oral cavity) and tuberculosis were present in 2-2 cases (3.57-3.57\%). There are no current smokers among these patients; prior smoking was confirmed in 8 cases, and there was a history of appendectomy in 2 case. 


\subsubsection{Surgical Procedures}

The laparoscopic technique was used in $33(58.9 \%)$ and the conventional method in 23 $(41.1 \%)$ cases. Twenty $(35.7 \%)$ of the surgical interventions were emergency procedures, while $36(64.3 \%)$ were elective interventions. The indication for emergency surgery was the presence of a severe, toxic condition, which was accompanied by bleeding in 4 cases, perforation and ileus in 1-1 cases, and severe malnutrition in 2 patients, whereas elective interventions were performed because of a condition that could not be controlled with conservative treatment.

The distribution and characteristics of the various surgical procedures are presented in Table 9.

\begin{tabular}{|c|c|c|c|c|}
\hline & & $\begin{array}{l}\text { Laparoscopy } \\
(\mathrm{n}=33)\end{array}$ & $\begin{array}{l}\text { Open surgery } \\
(n=23)\end{array}$ & \\
\hline \multirow[t]{4}{*}{ Two-stage surgery } & $\begin{array}{l}\text { i. Proctocolectomy, J-pouch, } \\
\text { ileostomy }\end{array}$ & $21(63.6 \%)$ & $5(21.7 \%)$ & \\
\hline & Duration of surgery (minutes) & 221 & 185 & $P=0.187$ \\
\hline & ii. Ileostomy closure & 17 & 5 & \\
\hline & Time from first surgery (months) & 3.8 & 4.4 & \\
\hline \multirow[t]{6}{*}{ Three-stage surgery } & $\begin{array}{l}i \text {. Total colectomy, mucous } \\
\text { fistula, end ileostomy }\end{array}$ & $9(27.2 \%)$ & $14(60.8 \%)$ & \\
\hline & Duration of surgery (minutes) & 186.88 & 151.54 & $* P=0,006$ \\
\hline & ii. J-pouch creation, ileostomy & 6 & 13 & \\
\hline & Time from first surgery (months) & 5 & 5.15 & \\
\hline & iii. Ileostomy closure & 6 & 12 & \\
\hline & Time from first surgery (months) & 7.83 & 9.25 & \\
\hline \multirow[t]{4}{*}{ One-stage surgery } & Rectum extirpation & $3(9 \%)$ & 0 & \\
\hline & Proctocolectomy, end ileostomy & 0 & $2(8.6 \%)$ & \\
\hline & $\begin{array}{l}\text { Colectomy, ileorectal } \\
\text { anastomosis }\end{array}$ & 0 & $1(4.3 \%)$ & \\
\hline & Total colectomy, ileostomy & 0 & $1(4.3 \%)$ & \\
\hline
\end{tabular}

Table 9. Distribution and characteristics of surgical procedures $* P \leq 0.05$

Following a histological diagnosis of Crohn's disease, the mucous fistula was converted to ileorectostomy in 2 case in the laparoscopic group. 


\subsubsection{Postoperative results}

There was no significant difference between the groups in the length of hospital stay, the time to the recovery of the bowel function, the number of days spent in the ICU, or the need for transfusion. There was no death in the perioperative period in either group.

\subsubsection{Long-term follow-up results}

During the long-term follow up there were no significant differences between the two groups regarding early postoperative complications. Of the 23 patients treated with infliximab, 6 developed an early postoperative complication. During the mean follow-up of 47 months, significantly fewer late complications occurred in the laparoscopic group (Table 10).

\begin{tabular}{|c|c|c|c|c|c|}
\hline & \multicolumn{2}{|l|}{ Laparoscopy $(n=33)$} & \multicolumn{3}{|l|}{ Open surgery $(n=23)$} \\
\hline & Complication & Therapy & Complication & Therapy & \\
\hline \multirow[t]{3}{*}{$\begin{array}{l}\text { Septic } \\
\text { condition }\end{array}$} & $\begin{array}{l}\text { Lesser pelvic } \\
\text { abscess (1) }\end{array}$ & $\begin{array}{l}\text { Radiological } \\
\text { intervention }\end{array}$ & $\begin{array}{l}\text { Lesser pelvic } \\
\text { abscess (1) }\end{array}$ & $\begin{array}{l}\text { Perianal } \\
\text { exploration }\end{array}$ & \\
\hline & Perianal abscess (1) & Seton drainage & Perianal abscess (9) & Seton drainage & \\
\hline & $\begin{array}{l}\text { Abdominal wall } \\
\text { abscess (1) }\end{array}$ & $\begin{array}{l}\text { Conservative } \\
\text { treatment }\end{array}$ & Severe pouchitis (1) & Pouch excision & \\
\hline Total & $9 \%(3 / 33)$ & & $47.8 \%(11 / 23)$ & & $* * * P=0.001$ \\
\hline \multirow{2}{*}{$\begin{array}{l}\text { Intestinal } \\
\text { obstruction }\end{array}$} & Ileus (1) & Reoperation & Ileus (5) & Reoperation & \\
\hline & Subileus (7) & $\begin{array}{l}\text { Conservative } \\
\text { treatment }\end{array}$ & Subileus (9) & $\begin{array}{l}\text { Conservative } \\
\text { treatment }\end{array}$ & \\
\hline Total & $24.2 \%(8 / 33)$ & & $60 \%(14 / 23)$ & & $* * P=0.006$ \\
\hline $\begin{array}{l}\text { Postoperative } \\
\text { hernia }\end{array}$ & $\begin{array}{l}\text { In the ileostomy } \\
\text { scar (3) }\end{array}$ & $\begin{array}{l}\text { Abdominal wall } \\
\text { reconstruction }\end{array}$ & $\begin{array}{l}\text { In midline } \\
\text { laparotomy scar (4) }\end{array}$ & $\begin{array}{l}\text { Abdominal wall } \\
\text { reconstruction }\end{array}$ & \\
\hline Total & $9 \%(3 / 33)$ & & $17.3 \%(4 / 23)$ & & $P=0.355$ \\
\hline \multirow[t]{5}{*}{ Other } & $\begin{array}{l}\text { Anastomotic } \\
\text { stenosis (1) }\end{array}$ & $\begin{array}{l}\text { Endoscopic } \\
\text { dilatation }\end{array}$ & $\begin{array}{l}\text { Anastomotic } \\
\text { stenosis (6) }\end{array}$ & $\begin{array}{l}\text { Surgical and } \\
\text { endoscopic } \\
\text { dilatation }\end{array}$ & \\
\hline & $\begin{array}{l}\text { Vascular failure of } \\
\text { terminal ileum (1) }\end{array}$ & $\begin{array}{l}\text { Resection of } \\
\text { ileum }\end{array}$ & Anal bleeding (3) & $\begin{array}{l}\text { Rectum } \\
\text { extirpation (1) }\end{array}$ & \\
\hline & & & $\begin{array}{l}\text { Severe sphincter } \\
\text { damage (1) }\end{array}$ & $\begin{array}{l}\text { Rectum } \\
\text { extirpation }\end{array}$ & \\
\hline & & & $\begin{array}{l}\text { Pouch-vaginal } \\
\text { fistula (2) }\end{array}$ & - & \\
\hline & & & Dehydration (2) & $\begin{array}{l}\text { Conservative } \\
\text { treatment }\end{array}$ & \\
\hline Total & $6 \%(2 / 33)$ & & $60 \%(14 / 23)$ & & $* P=0.01$ \\
\hline
\end{tabular}

Table 10. Late postoperative complications and treatment (after 30 days) during the longterm follow up. $* P \leq 0.05, * * P \leq 0.01, * * * P \leq 0.001$ 
During the follow-up, 2 patients died, as a result of an oral cavity tumour or a cardiorespiratory insufficiency; the causes of death were not related to the UC. During the course of the follow-up, there were 9 and 12 urgent admissions to a medical unit because of need for transfusion and abdominal pain.

The clinical symptoms and endoscopic findings confirmed 17 cases of pouchitis $(7$ in the laparoscopic group and 10 in the open surgery group), affecting $40 \%$ of the patients with a pouch. The inflammation of the pouch was accompanied by cuffitis in 10 cases. During the follow-up period, wound infection was detected in 8 patients in the laparoscopic group (5 in the wound line, 1 on the perineum, 1 at the site of the drain, and 1 at the site of re-suture on the abdominal wall), and in 7 patients in the open surgery group (4 in the wound line, 1 at the site of the closed ileostomy, 1 at the site of the drain, and 1 at the site of the mucous fistula. MRSA infection was confirmed in 2 patients in the laparoscopic group and 1 patient in the open surgery group. Changes in the general condition, the body weight, the number of stools daily, and the cosmetic results after the surgical interventions were also assessed.

A significant improvement in the general status (scale from 1 to 10$)(P=0.000$ and $P=0.000$ ) was measured in both groups after the surgery. The preoperative and current body weights indicated an increase in both groups, which was significant $(P=0.033)$ in the open surgery patient population. There was a decreasing tendency of the postoperative mean number of stools daily in the two patient groups. From the aspect of the cosmetic result, those patients who had undergone open surgery were on average "rather satisfied", while the laparoscopic patients were on average "very satisfied" on a five-item scale.

\subsection{Evaluate quality of life after surgery for $U C$ by investigating the connection between gastroenterological and psychological conditions, daily activities (Study III.)}

\subsubsection{Patients}

41 patients had undergone laparoscopic surgery, and 17 patients had had open surgeries. Thirty-nine cases were elective interventions, while 19 were emergency surgery. No significant difference was found in the case of the BMI (24.85 vs. 26.82) or the ASA score (2.25 vs. 2.13). There was an average 8.2 years from diagnosing the disease to surgery. In the laparoscopic group, 25 proctocolectomies with IPAA and ileostomy were performed, 13 patients had a total colectomy with end ileostomy and mucous fistula, and 3 rectum 
extirpations were carried out. In the open group, a pouch was created in 4 cases, 9 patients had a total colectomy with mucous fistula, and 4 other colon resections were performed. 17 patients had a stoma during the study. In order to homogenize the groups, 6 patients, who were operated dissimilarly from the standard surgical technique ( $n=3$ rectum extirpation, $n=3$ other colon resection) were excluded during the comparison of laparoscopic and open surgery groups, and during the analysis of complications.

\subsubsection{Representation of illnesses}

92.3\% of the patients enrolled in the study considered a psychological factor (psychological causes, family or work stress) to be in the background of their disease. $42.3 \%$ of the patients pointed to genetic factors, $46.2 \%$ of them mentioned environmental hazards (such as inappropriate diet), and 1 patient noted the Chernobyl nuclear disaster as the cause of the disease. Patients viewing genetic factors as being in the background of the disease reached significantly higher scores on the BIPQ (44.14 vs. $35.73 ; P=0.022)$, so they are more threatened by their disease and know less about the nature of it (coherence subscale: 2.14 vs. $1.10 ; P=0.013)$.

\subsubsection{Psychological consequences of having a stoma}

There were differences in personal control between patients with a stoma $(n=17)$ and patients without a stoma $(\mathrm{n}=41)(6.12$ vs. $4.12 ; P=0.045)$. Patients with a stoma felt they had less control over their disease. No difference was found between the two groups during gastroenterological follow-up examinations.

\subsubsection{Results for emotional state and mood}

There was a significant connection between depression and the functional scoring system $(P=0.002 ; \mathrm{r}=0.419)$, the GIQLI $(P<0.001 ; \mathrm{r}=-0.867)$, the SIBDQ $(P<0.001 ; \mathrm{r}=-0.795)$ and the BIPQ $(P<0.001 ; \mathrm{r}=0.751)$, as well as the consequences, personal and treatment control, identity, concern and emotional representation subscales $(P<0.05$ in all cases). State anxiety significantly correlated with the total score for the GIQLI $(P<0.001, \mathrm{r}=-0.624)$, the SIBDQ $(P<0.001, \mathrm{r}=-0.579)$ and the BIPQ $(P<0.001, \mathrm{r}=0.615)$, as well as with the consequences, personal and treatment control, identity, concern and emotional representation subscales $(P<0.05$ in all cases). There was a significant connection between trait anxiety and the functional scoring system $(P=0.012 ; \mathrm{r}=0.344)$, the GIQLI $(P<0.001 ; \mathrm{r}=-0.682)$, the SIBDQ $(P<0.001 ; \mathrm{r}=-0.684)$ and the BIPQ $(P<0.001 ; \mathrm{r}=0.608)$, as well as the consequences, personal 
and treatment control, identity, concern and emotional representation subscales $(P<0.001)$ (Table 11).

\begin{tabular}{lc}
\hline Variables & GIQLI \\
\hline Psychological variables & $-0.87^{* *}$ \\
\hline Beck Depression Inventory & $-0.62^{* *}$ \\
Spielberger's State Anxiety Scale & $-0.69^{* *}$ \\
Spielberger's Trait Anxiety Scale & $-0.84^{* *}$ \\
Brief Illness Perception Questionnaire & $-0.89^{* *}$ \\
Consequences & $-0.07^{(\mathrm{NS})}$ \\
Timeline & $-0.37^{* *}$ \\
Personal control & $-0.39^{* *}$ \\
Treatment control & $-0.73^{* *}$ \\
Identity & $-0.71^{* *}$ \\
Concern & $-0.01^{(\mathrm{NS})}$ \\
Coherence & $-0.78^{* *}$ \\
\hline Emotional representation & \\
\hline Clinical variables & $-0.55^{* *}$ \\
\hline Functional scoring system & $0.89^{* *}$ \\
\hline Short Inflammatory Bowel Disease Questionnaire & \\
\hline
\end{tabular}

Table 11. Pearson's or Spearman's correlation between clinical and psychological variables and Gastrointestinal Quality of Life Index (GIQLI)

$* * P \leq 0.01 ; \mathrm{NS}$ : non significant

\subsubsection{Comparing laparoscopy and open surgery}

Trait anxiety was significantly lower in patients having undergone laparoscopic surgery $(n=38)$ compared with patients who had had open surgery $(n=14)(P=0.018)$ (average value of trait anxiety in patients with open surgery was $48.71, \mathrm{SD}=10.91$; this value was 40.22 , $\mathrm{SD}=9.82$ in the laparoscopic group). Both patient groups had $>5$ stools in the daytime and $>1$ at night per week, with no significant difference observed between the groups. No difference was noted between the two surgical methods based on the total score on the gastroenterological questionnaires, although the following statistical differences were found 
when evaluating each questionnaire item individually. Incontinence was registered during the day and at night in both patient groups (Table 12).

\begin{tabular}{lll}
\hline & $\begin{array}{l}\text { Laparoscopy } \\
(\mathrm{n}=28) \mathrm{n}(\%)\end{array}$ & $\begin{array}{l}\text { Open surgery } \\
(\mathrm{n}=11) \mathrm{n}(\%)\end{array}$ \\
\hline $\begin{array}{l}\text { Urgency (Inability to defer evacuation } \geq 30 \\
\text { minutes) }\end{array}$ & $14(50)$ & $6 \quad(54.5)$ \\
Evacuation difficulties & $5 \quad(17.85)$ & $3(27.3)$ \\
Soiling or seepage in daytime & $7(25)$ & $3(27.3)$ \\
Soiling or seepage at night & $11(39.28)$ & $6(54.5)$ \\
Perianal soreness & $15(53.57)$ & $9(81.8)$ \\
Protective pad in daytime & $7(25)$ & $3(27.3)$ \\
Protective pad at night & $12(42.85)$ & $3(27.3)$ \\
Dietary restrictions & $21(75)$ & $5(45.5)$ \\
Medication (continuous or occasional) & $14(50)$ & $10(90.9)$ \\
Social handicap & $13(46.6)$ & $4(36.4)$ \\
\hline
\end{tabular}

Table 12. Total values from the functional scoring system (Based on Ref. ${ }^{[14]}$ )

The incidence of abdominal pain was significantly less common (1.895 vs. $2.769 ; P=0.024)$ in the laparoscopic group based on the GIQLI.

\subsubsection{Complications}

No difference was found between the minimally invasive and conventional methods in cases requiring early reoperation (ileus, stoma correction, bleeding and sepsis) and in cases not requiring reoperation (subileus, bleeding, septic condition, pancreatitis and dehydration). There were significantly more late complications (septic condition, intestinal obstruction, postoperative hernia and "other" complications, such as bleeding, anastomotic stenosis, pouch-vaginal fistula, perforation and disruption of the abdominal wall) in patients who had undergone open surgery $(P=0.001)$, of whom the incidence of intestinal obstruction and "other" complications were significantly higher $(P \leq 0.001)$ (Figure 1). 


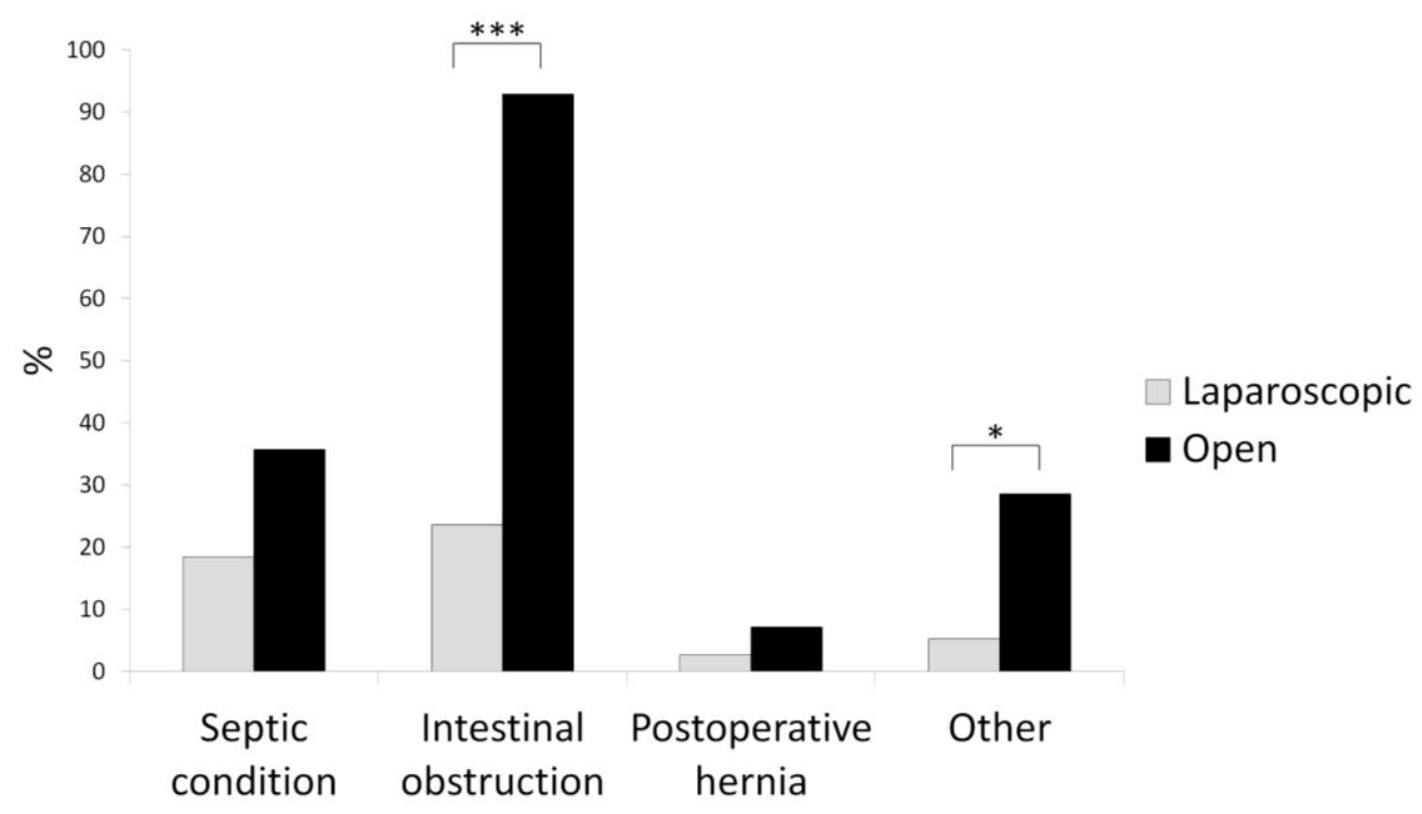

Figure 1. Late postoperative complications

Among late complications the incidence of intestinal obstruction and "other" complications were significantly higher in patients who had had open surgery than in patients who had undergone laparoscopic surgery. $* P \leq 0.05, * * * P \leq 0.001$

Pouchitis was detected in 17 cases (35.41\% of patients with a pouch). Cuffitis occurred in 13 $(27.08 \%)$ cases. The personal control $(3.43 \pm 2.35$ vs. $5.57 \pm 3.31 ; P=0.024)$ was higher in patients with no late complication.

\subsubsection{Headache}

As a result, $43(74.1 \%)$ patients had headaches, of whom $27(62.8 \%)$ had primary headache and $16(37.2 \%)$ had the secondary (symptomatic) type. Among the primary headaches $(n=27)$, tension-type headache was the most common, occurring in 19 (70.4\%) cases, of which 17 $(89.5 \%)$ patients experienced episodic tension-type headache and $2(10.5 \%)$ suffered from chronic tension-type headache; in addition, 8 (29.6\%) patients had migraine. Headache influenced quality of life and daily activities slightly to moderately in $79.1 \%(n=34)$ of the patients. No difference was found regarding headaches in the laparoscopic and open surgery groups and between patients with a stoma and those without a stoma. In the case of patients with headache, the BIPQ score was significantly higher $(P=0.036)$. 


\section{DISCUSSION}

The epidemiological data reveal that the incidence of UC is constantly rising ${ }^{[1]}$. The treatment of UC is primarily based on medical/biological therapy. A surgical intervention is considered in the event of the failure of the conservative therapy and the emergence of severe complications of the disease. An estimated $25-45 \%$ of patients with UC needs surgery at some time ${ }^{[1,5,6]}$. The use of minimally invasive surgical technique gathers ground widely also in Hungary, which can be applied safely during the therapy of IBD ${ }^{[21-23]}$. First proctocolectomy with pouch was performed by Parks et al. in 1978, which became the gold-standard technique during the surgical treatment of UC, while its laparoscopic implementation was first mentioned in the early '90s $[8,10,24]$. Proctocolectomy and IPAA creation are adequate alternatives in the surgical treatment of UC, and are currently the most frequently chosen types of surgery ${ }^{[8,25-27]}$. Rather limited experience is available, however, as regards the short and long-term results of the laparoscopic surgical management of UC. Limited data are available on quality of life in patients with UC undergoing surgery.

In our study, the perioperative results on patients with UC were analyzed retrospectively in order to compare the laparoscopic and open surgical techniques, with a short- and long-term follow-up. The preoperative laboratory test results revealed a significant difference between the two groups in WBC count and CRP. The preoperative laboratory data for the patients who participated in emergency surgery indicated an increased inflammatory response. Extraintestinal manifestations were found in 42 cases. A number of studies have demonstrated that smoking has a protective effect against the development and the relapse of $\mathrm{UC}^{[1,28]}$, and the finding was similar with appendectomy as a protective factor ${ }^{[1,29]}$. There were no current smokers in our patient population, but a history of smoking was present in 8 cases, and 2 patients had undergone appendectomy previously. There was no difference between the open surgery and laparoscopic groups as concerns the length of the hospital stay, the number of days spent in the ICU, the blood loss, or the time required for the recovery of the bowel function.

The minimally invasive technique has also gained popularity in the treatment of UC and, similarly to the open technique, can be used safely ${ }^{[23]}$. Its advantages include a shorter hospital stay, less postoperative pain, a shorter time for recovery of the bowel function and a better cosmetic result, but it has the disadvantage of a longer duration of surgery ${ }^{[11]}$. A considerable number of the studies published to date have reported on the various advantages of the laparoscopic technique. An Australian study found that laparoscopy is associated with a 
shorter hospital stay, a faster recovery of the bowel function, and a better cosmetic result; however, the two surgical techniques have the same morbidity rate due to the proctocolectomy ${ }^{[30]}$. Laparoscopic completion proctectomy and IPAA creation following laparoscopic colectomy were studied by $G u$ et al., who reported a low blood loss, rapid recovery of the bowel function, and a short hospital stay ${ }^{[31]}$. A Dutch study on colectomies performed because of non-toxic colitis concluded that the minimally invasive technique is more advantageous in cases involving wound infection and abdominal abscess ${ }^{[32]}$. Koh et al. demonstrated that the laparoscopic technique was safe in emergency surgery for UC, and yielded better results in cases of ileus and wound infection as compared with open surgery ${ }^{[33]}$. Similarly advantageous results concerning the hospital stay, the need for blood transfusion, the cosmetic result and wound infection were reported from two US studies on emergency laparoscopic subtotal colectomies ${ }^{[34,35]}$. Current data available in a large international database confirm better rates of both morbidity and mortality in the minimally invasive patient group ${ }^{[21]}$. Our own results indicate that, other than the cosmetic results, laparoscopic surgery has no clear advantage in the perioperative period. However, the duration of surgery differed significantly in the two patient groups: the laparoscopic interventions took longer to complete.

Fajardo et al. did not also observe a difference in the rate of morbidity during the short-term follow-up of two-stage laparoscopic and open IPAA surgery ${ }^{[36]}$. A meta-analysis published in 2010 did not find a difference between the conventional open and the minimally invasive procedure from the aspect of complications such as a lesser pelvic abscess, anastomotic leakage and ileus ${ }^{[37]}$. Similarly, a recent randomized study likewise confirmed only the cosmetic advantage of the laparoscopic method ${ }^{[38]}$.

Complications were classified as early (within 30 days) or late (after 30 days) with regard to their onset after primary surgery. Our study led to the finding that the minimally invasive method does not have an advantage as concerns the early complications, but it is demonstrably more advantageous in terms of the incidence of late complications. Our study indicated that only $26 \%$ of patients who had received infliximab treatment had early postoperative complications and therefore suggests that prior biological therapy is not associated with a higher rate of complications. In several studies, prior biological therapy was

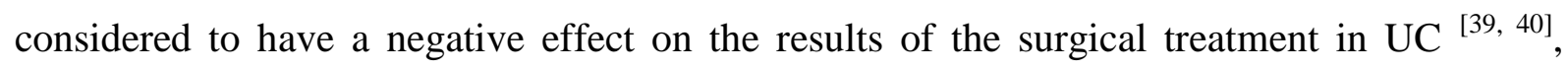
although this is not supported by other observations ${ }^{[5,41,42]}$ or a most recent case-matched study ${ }^{[43]}$. During the mean follow-up of 47 months, significantly fewer complications, 
involving an intestinal obstruction, a septic condition and "other complications" occurred in the laparoscopic group. The obvious explanation for the higher, but not significant rate of hernias in the open surgery group is the more extensive entry opening. The higher rate of ileus and subileus in the open surgery group is probably caused by the higher level of surgical trauma and the adhesions due to the wound surface. Hull et al. observed significantly more cases of adhesion after open IPAA surgery, and a similar result was reported by Indar et al. [44, 45]. The research by Bartels et al. revealed that the incidence of adhesions and postoperative hernias was significantly higher following emergency open colectomies performed because of UC ${ }^{[46]}$.

One of the most common complication in the long term after IPAA surgery performed because of UC is pouchitis ${ }^{[47,48]}$. A total of 17 cases of pouchitis were recorded in our study, corresponding to $40 \%$ of the patients with a pouch. The exact aetiology of pouchitis is still unknown; no independent risk factor has been recognized. The study by Kalkan et al. pointed to the fulminant colitis leading to the surgery and the steroid dependence as the possible causes of pouchitis, whereas Uchino et al. were of the opinion that a toxic megacolon and the onset of UC before the age of 26 years may predispose to chronic pouchitis ${ }^{[49,50]}$. There was a decreasing tendency of the postoperative mean number of stools daily and an increase in the postoperative body weights in the two patient groups. Polle et al. did not detect a difference in the quality of life, the morbidity rate or the functional results following open and laparoscopic proctocolectomies, but confirmed a better cosmetic result among laparoscopic female patients [51]. An Italian study emphasized the importance of the accurate assessment, selection and follow-up of surgical patients with regard to complications, pouchitis, pouch excision, the risk of cancer and the quality of life following IPA surgery ${ }^{[52]}$. Success of the surgical intervention is determined by quality of life in case of a benign, non-neoplastic disease. In case of UC, abdominal complaints, high number of bowel movements a day, surgical interventions and their consequences are very demanding somatically and psychologically. Social integration of patients, their quality of life and daily routine activities may often be difficult. Regarding disease representation, $92.3 \%$ of our patients considered their disease to be caused by psychological factors, $42.3 \%$ thought that genetic factors were behind the disease, and $46.2 \%$ though that their disease was caused by environmental hazards. In conclusion, patients with UC are well informed, and are aware of the nature and characteristics of their disease. Consequences of wearing a stoma were examined as well, which was significant regarding the "Personal control" subscale of the BIPQ, patients with a 
stoma felt less control over their condition. Therefore the presence of an anus prae either temporary or permanent, was psychologically demanding for the patients, it made healing and daily activities more difficult. Besides these results, no difference was found in quality of life of patients living with an ileostoma or a pouch in a prospective cross-sectional observational study ${ }^{[53]}$. Quality of life was examined regarding laparoscopic surgery and open surgery as well. Examination of psychological differences between the two groups showed that trait anxiety and the average value of "Treatment control" subscale of BIPQ were significantly different, that is patients having open surgery were more anxious and had less faith in the success of the surgical treatment. Based on the total score of gastroenterological questionnaires, there was no difference between the two surgical methods, although perianal and abdominal pain, stress, social and recreational activities were more favorable in the laparoscopic group based on the Functional score system, the SIBDQ and the GIQLI. A German and an Irish study with 10-year follow-up found favorable quality of life after IPAA surgery ${ }^{[54,55]}$. Nutritional difficulties, bowel movement problems, as well as daily and nighttime incontinence were found in both groups. Incontinence, increased number of bowel movements at night and bowel urgency were found to be negative prognostic factors of quality of life in the literature ${ }^{[56]}$. Our patients reported $>5$ stools a day and $>1$ stool at night weekly in the postoperative period. Fischera et al. found high rates of continence and an average of 6 bowel movements a day after laparoscopic IPAA ${ }^{[9]}$. No difference was found between the two groups regarding early complications; these complications were more common in shorter and thinner patients. Late complications occurred significantly more often in case of emergency and open surgeries. The values of "Personal control" and "Understanding" subscales of BIPQ regarding psychological factors were higher in patients having no late complications, so who felt more control over their disease. Early and late complications correlated with the "Understanding" subscale of BIPQ, so patients having no complication understand their disease more. Logistic regression was used to confirm that the laparoscopic intervention and the "Understanding" subscale of BIPQ were predictive regarding the development of complications, that is the incidence of complications is lower in case of laparoscopic surgeries and in patients understanding their disease better. Significant correlation was found between the results of psychological and gastrointestinal questionnaires, negative emotional condition and mood resulted in lower quality of life, patients were more anxious and depressive, these patients had a negative image of their disease, and had less faith in the success of the surgical interventions (Figure 2). 


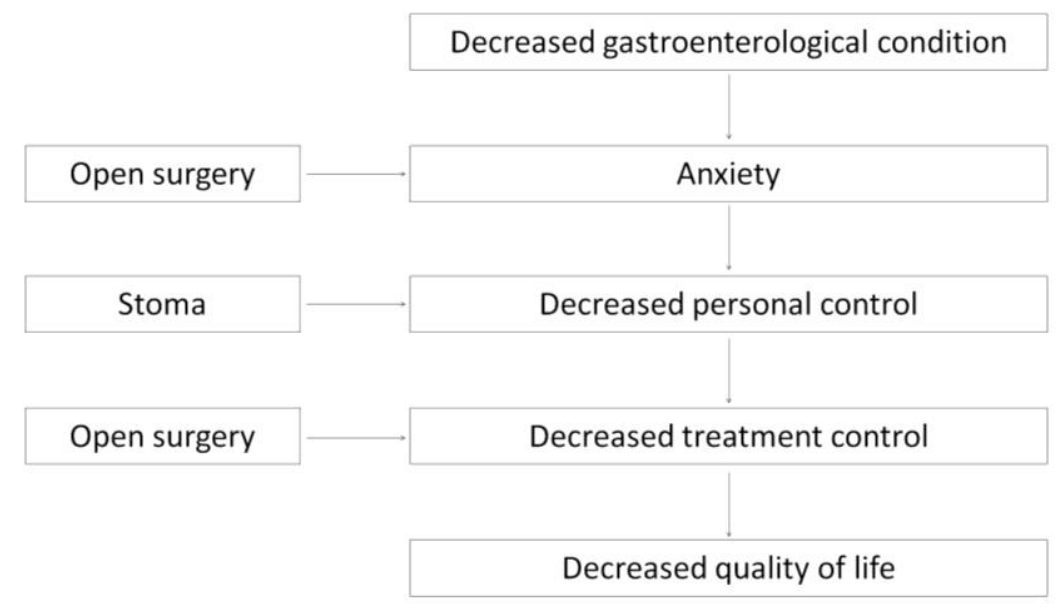

Figure 2. Effect of gastroenterological and psychological conditions and surgical technique on quality of life

$74.1 \%$ of our patients had headaches, $79.1 \%$ of these patients had slight to moderate problems with everyday life. Based on the results of BIPQ, headache further worsened the emotional condition of our patients. It should be emphasized that patients having headaches had mainly tension type headaches, stress and psychological tension have primary role in the development of tension headaches ${ }^{[57,58]}$. Tension type headache negatively influences quality of life ${ }^{[59]}$.

\section{CONCLUSION}

$i$. Our working group was the first to publish short- and long-term results on laparoscopic treatment of UC in Hungary, which proved the success of the method.

ii. Laparoscopic surgical treatment can be used safely for both emergency and elective cases in UC patients. During the long-term follow-up period, significantly fewer late complications occurred in the laparoscopically operated group of patients.

iii. Our study is the first to examine quality of life among patients operated with laparoscopy on UC with regard to psychological and gastroenterological conditions. The long-term positive effect of laparoscopic surgery was confirmed regarding quality of life.

$i v$. Favourable gastroenterological condition leads to better psychological state and favourable quality of life, which can be negatively influenced by having a stoma, headache or complications. 
$v$. Successful treatment of UC should be performed in centers with close gastroenterological and surgical co-operation.

vi. Psychological guiding is essential. Psychologists, neurologists and social workers may have to be involved in the treatment of these patients. 


\section{ACKNOWLEDGEMENTS}

I would like to express my sincere gratitude to those who have supported me during my scientific work.

György Lázár, Professor and Head of the Department of Surgery, University of Szeged, and Doctor of Science, Hungarian Academy of Sciences. With your huge knowledge and continuous support, you gave me a secure background in my research work. Thank you for your excellent scientific guidance since my undergraduate years.

My colleagues and friends

Melinda Látos, Klaudia Farkas, Tamás Molnár Professor, my co-authors. Thank you for your indispensable help during the quality of life survey. Zsolt Simonka, Attila Paszt, Szabolcs Ábrahám, my colleagues and co-authors, thank you for all the help you gave me during the studies.

I wish to express my special gratitude to my family.

My mother, Ilona, my father, János, my brother Máté, my grandparents, Ilona, Piroska and János. You made all this possible with your enormous love and encouragement. Thank you for your continuous support and for showing me how to live a valuable life.

My wife, Anett. Thank you for your endless love and all the support you gave me. My two beautiful sons, János and Márk. You are the biggest gift in my life.

And I would like to thank my parents-in-law, Mária and Ferenc, my sister-in-law, Szandra for your love. 


\section{REFERENCES}

1. Kovács Á, Lakatos L. Gyulladásos bélbetegségek. Medicina; 2011.

2. Vegh Z, Burisch J, Pedersen N, Kaimakliotis I, Duricova D, Bortlik M, Avnstrom S, Vinding KK, Olsen J, Nielsen KR, Katsanos KH, Tsianos EV, Lakatos L, Schwartz D, Odes S, Lupinacci G, De Padova A, Jonaitis L, Kupcinskas L, Turcan S, Tighineanu O, Mihu I, Barros LF, Magro F, Lazar D, Goldis A, Fernandez A, Hernandez V, Niewiadomski O, Bell S, Langholz E, Munkholm P, Lakatos PL, EpiCom g. Incidence and initial disease course of inflammatory bowel diseases in 2011 in Europe and Australia: results of the 2011 ECCOEpiCom inception cohort. J Crohns Colitis 2014;8:1506-1515.

3. Miheller P, Nagy F, Palatka K, Altorjay I, Horvath G, Lorinczy K, Ujszaszy L, Viranyi Z, Szepes A, Molnar T, Farkas K, Szepes Z, Nyari T, Wittmann T, Tulassay Z. [Hungarian data on inflammatory bowel diseases: analytical data on ulcerative colistis]. Orv Hetil 2012;153:702-712.

4. Shouval DS, Rufo PA. The Role of Environmental Factors in the Pathogenesis of Inflammatory Bowel Diseases: A Review. JAMA Pediatr 2017.

5. Ferrante M, Declerck S, De Hertogh G, Van Assche G, Geboes K, Rutgeerts P, Penninckx

F, Vermeire S, D'Hoore A. Outcome after proctocolectomy with ileal pouch-anal anastomosis for ulcerative colitis. Inflamm Bowel Dis 2008;14:20-28.

6. Roses RE, Rombeau JL. Recent trends in the surgical management of inflammatory bowel disease. World J Gastroenterol 2008;14:408-412.

7. Jacobs M, Verdeja JC, Goldstein HS. Minimally invasive colon resection (laparoscopic colectomy). Surg Laparosc Endosc 1991;1:144-150.

8. Bennis M, Tiret E. Surgical management of ulcerative colitis. Langenbecks Arch Surg 2012;397:11-17.

9. Fichera A, Silvestri MT, Hurst RD, Rubin MA, Michelassi F. Laparoscopic restorative proctocolectomy with ileal pouch anal anastomosis: a comparative observational study on long-term functional results. J Gastrointest Surg 2009;13:526-532.

10. Peters WR. Laparoscopic total proctocolectomy with creation of ileostomy for ulcerative colitis: report of two cases. J Laparoendosc Surg 1992;2:175-178.

11. Zoccali M, Fichera A. Minimally invasive approaches for the treatment of inflammatory bowel disease. World J Gastroenterol 2012;18:6756-6763. 
12. Pellino G, Sciaudone G, Miele E, Candilio G, De Fatico GS, Riegler G, Staiano A, Canonico S, Selvaggi F. Functional outcomes and quality of life after restorative proctocolectomy in paediatric patients: a case-control study. Gastroenterol Res Pract 2014;2014:340341.

13. Pica R, Cassieri C, Pronio AM, Zippi M, Avallone EV, Montesani C, Occhigrossi G, Paoluzi P. Quality of life in ulcerative colitis patients treated medically versus patients undergoing surgery. Eur Rev Med Pharmacol Sci 2014;18:693-698.

14. Oresland T, Fasth S, Nordgren S, Hulten L. The clinical and functional outcome after restorative proctocolectomy. A prospective study in 100 patients. Int J Colorectal Dis 1989;4:50-56.

15. Eypasch E, Williams JI, Wood-Dauphinee S, Ure BM, Schmulling C, Neugebauer E, Troidl H. Gastrointestinal Quality of Life Index: development, validation and application of a new instrument. Br J Surg 1995;82:216-222.

16. Guyatt G, Mitchell A, Irvine EJ, Singer J, Williams N, Goodacre R, Tompkins C. A new measure of health status for clinical trials in inflammatory bowel disease. Gastroenterology 1989;96:804-810.

17. Beck AT, Ward CH, Mendelson M, Mock J, Erbaugh J. An inventory for measuring depression. Arch Gen Psychiatry 1961;4:561-571.

18. Spielberger CD, Gorsuch RL, Lushene RE. Manual for the state-trait anxiety inventory. Palo Alto: Consulting Psychologists Press; 1970.

19. Broadbent E, Petrie KJ, Main J, Weinman J. The brief illness perception questionnaire. $J$ Psychosom Res 2006;60:631-637.

20. Headache Classification Committee of the International Headache S. The International Classification of Headache Disorders, 3rd edition (beta version). Cephalalgia 2013;33:629808.

21. Causey MW, Stoddard D, Johnson EK, Maykel JA, Martin MJ, Rivadeneira D, Steele SR. Laparoscopy impacts outcomes favorably following colectomy for ulcerative colitis: a critical analysis of the ACS-NSQIP database. Surg Endosc 2013;27:603-609.

22. Hata K, Kazama S, Nozawa H, Kawai K, Kiyomatsu T, Tanaka J, Tanaka T, Nishikawa T, Yamaguchi H, Ishihara S, Sunami E, Kitayama J, Watanabe T. Laparoscopic surgery for ulcerative colitis: a review of the literature. Surg Today 2015;45:933-938.

23. Sica GS, Biancone L. Surgery for inflammatory bowel disease in the era of laparoscopy. World J Gastroenterol 2013;19:2445-2448. 
24. Parks AG, Nicholls RJ. Proctocolectomy without ileostomy for ulcerative colitis. $\mathrm{Br} \mathrm{Med}$ $J$ 1978;2:85-88.

25. Biondi A, Zoccali M, Costa S, Troci A, Contessini-Avesani E, Fichera A. Surgical treatment of ulcerative colitis in the biologic therapy era. World $J$ Gastroenterol 2012;18:1861-1870.

26. Ikeuchi H, Uchino M, Matsuoka H, Bando T, Matsumoto T, Tomita N, Syoji Y, Kusunoki M, Yamamura T, Utsunomiya J. Surgery for ulcerative colitis in 1,000 patients. Int J Colorectal Dis 2010;25:959-965.

27. Lefevre JH, Bretagnol F, Ouaissi M, Taleb P, Alves A, Panis Y. Total laparoscopic ileal pouch-anal anastomosis: prospective series of 82 patients. Surg Endosc 2009;23:166-173.

28. Tobin MV, Logan RF, Langman MJ, McConnell RB, Gilmore IT. Cigarette smoking and inflammatory bowel disease. Gastroenterology 1987;93:316-321.

29. Gilat T, Dotan I. Ulcerative colitis and appendectomy. What is the nature of the (negative) association? Ital J Gastroenterol Hepatol 1997;29:212-213.

30. Tan JJ, Tjandra JJ. Laparoscopic surgery for ulcerative colitis - a meta-analysis. Colorectal Dis 2006;8:626-636.

31. Gu J, Stocchi L, Geisler DP, Kiran RP. Staged restorative proctocolectomy: laparoscopic or open completion proctectomy after laparoscopic subtotal colectomy? Surg Endosc 2011;25:3294-3299.

32. Bartels SA, Gardenbroek TJ, Ubbink DT, Buskens CJ, Tanis PJ, Bemelman WA. Systematic review and meta-analysis of laparoscopic versus open colectomy with end ileostomy for non-toxic colitis. Br J Surg 2013;100:726-733.

33. Koh FH, Tan KK, Tsang CB, Koh DC. Laparoscopic versus an open colectomy in an emergency setting: a case-controlled study. Ann Coloproctol 2013;29:12-16.

34. Bell RL, Seymour NE. Laparoscopic treatment of fulminant ulcerative colitis. Surg Endosc 2002;16:1778-1782.

35. Telem DA, Vine AJ, Swain G, Divino CM, Salky B, Greenstein AJ, Harris M, Katz LB. Laparoscopic subtotal colectomy for medically refractory ulcerative colitis: the time has come. Surg Endosc 2010;24:1616-1620.

36. Fajardo AD, Dharmarajan S, George V, Hunt SR, Birnbaum EH, Fleshman JW, Mutch MG. Laparoscopic versus open 2-stage ileal pouch: laparoscopic approach allows for faster restoration of intestinal continuity. J Am Coll Surg 2010;211:377-383.

37. Wu XJ, He XS, Zhou XY, Ke J, Lan P. The role of laparoscopic surgery for ulcerative colitis: systematic review with meta-analysis. Int J Colorectal Dis 2010;25:949-957. 
38. Schiessling S, Leowardi C, Kienle P, Antolovic D, Knebel P, Bruckner T, Kadmon M, Seiler CM, Buchler MW, Diener MK, Ulrich A. Laparoscopic versus conventional ileoanal pouch procedure in patients undergoing elective restorative proctocolectomy (LapConPouch Trial)-a randomized controlled trial. Langenbecks Arch Surg 2013;398:807-816.

39. Mor IJ, Vogel JD, da Luz Moreira A, Shen B, Hammel J, Remzi FH. Infliximab in ulcerative colitis is associated with an increased risk of postoperative complications after restorative proctocolectomy. Dis Colon Rectum 2008;51:1202-1207; discussion 1207-1210.

40. Selvasekar CR, Cima RR, Larson DW, Dozois EJ, Harrington JR, Harmsen WS, Loftus EV, Jr., Sandborn WJ, Wolff BG, Pemberton JH. Effect of infliximab on short-term complications in patients undergoing operation for chronic ulcerative colitis. J Am Coll Surg 2007;204:956-962; discussion 962-953.

41. Kunitake H, Hodin R, Shellito PC, Sands BE, Korzenik J, Bordeianou L. Perioperative treatment with infliximab in patients with Crohn's disease and ulcerative colitis is not associated with an increased rate of postoperative complications. J Gastrointest Surg 2008;12:1730-1736; discussion 1736-1737.

42. Schluender SJ, Ippoliti A, Dubinsky M, Vasiliauskas EA, Papadakis KA, Mei L, Targan SR, Fleshner PR. Does infliximab influence surgical morbidity of ileal pouch-anal anastomosis in patients with ulcerative colitis? Dis Colon Rectum 2007;50:1747-1753.

43. Coquet-Reinier B, Berdah SV, Grimaud JC, Birnbaum D, Cougard PA, Barthet M, Desjeux A, Moutardier V, Brunet C. Preoperative infliximab treatment and postoperative complications after laparoscopic restorative proctocolectomy with ileal pouch-anal anastomosis: a case-matched study. Surg Endosc 2010;24:1866-1871.

44. Hull TL, Joyce MR, Geisler DP, Coffey JC. Adhesions after laparoscopic and open ileal pouch-anal anastomosis surgery for ulcerative colitis. Br J Surg 2012;99:270-275.

45. Indar AA, Efron JE, Young-Fadok TM. Laparoscopic ileal pouch-anal anastomosis reduces abdominal and pelvic adhesions. Surg Endosc 2009;23:174-177.

46. Bartels SA, Vlug MS, Henneman D, Ponsioen CY, Tanis PJ, Bemelman WA. Less adhesiolysis and hernia repair during completion proctocolectomy after laparoscopic emergency colectomy for ulcerative colitis. Surg Endosc 2012;26:368-373.

47. Helavirta I, Huhtala H, Hyoty M, Collin P, Aitola P. Restorative proctocolectomy for ulcerative colitis IN 1985-2009. Scand J Surg 2015.

48. Sagar PM, Pemberton JH. Intraoperative, postoperative and reoperative problems with ileoanal pouches. Br J Surg 2012;99:454-468. 
49. Kalkan IH, Dagli U, Onder FO, Tunc B, Oztas E, Ulker A, Sasmaz N. Evaluation of preoperative predictors of development of pouchitis after ileal-pouch-anastomosis in ulcerative colitis. Clin Res Hepatol Gastroenterol 2012;36:622-627.

50. Uchino M, Ikeuchi H, Matsuoka H, Bando T, Takesue Y, Tomita N. Clinical features and management of pouchitis in Japanese ulcerative colitis patients. Surg Today 2013;43:10491057.

51. Polle SW, Dunker MS, Slors JF, Sprangers MA, Cuesta MA, Gouma DJ, Bemelman WA. Body image, cosmesis, quality of life, and functional outcome of hand-assisted laparoscopic versus open restorative proctocolectomy: long-term results of a randomized trial. Surg Endosc 2007;21:1301-1307.

52. Delaini GG, Scaglia M, Colucci G, Hulten L. The ileoanal pouch procedure in the longterm perspective: a critical review. Tech Coloproctol 2005;9:187-192.

53. Kuruvilla K, Osler T, Hyman NH. A comparison of the quality of life of ulcerative colitis patients after IPAA vs ileostomy. Dis Colon Rectum 2012;55:1131-1137.

54. Browne C, Shaikh F, Iqbal N, McGovern B, Rowe S, Neary P. Quality of life, continence and frequency of pouchitis following laparoscopic versus open colectomy and ileal pouchanal anastomosis: an Irish perspective. Ir J Med Sci 2015;184:655-658.

55. Leowardi C, Hinz U, Tariverdian M, Kienle P, Herfarth C, Ulrich A, Kadmon M. Longterm outcome 10 years or more after restorative proctocolectomy and ileal pouch-anal anastomosis in patients with ulcerative colitis. Langenbecks Arch Surg 2010;395:49-56.

56. Andersson T, Lunde OC, Johnson E, Moum T, Nesbakken A. Long-term functional outcome and quality of life after restorative proctocolectomy with ileo-anal anastomosis for colitis. Colorectal Dis 2011;13:431-437.

57. Clark GT, Sakai S, Merrill R, Flack VF, McCreary C. Cross-correlation between stress, pain, physical activity, and temporalis muscle EMG in tension-type headache. Cephalalgia 1995; 15:511-518, discussion 451.

58. Torelli P, Abrignani G, Castellini P, Lambru G, Manzoni GC. Human psyche and headache: tension-type headache. Neurol Sci 2008;29 Suppl 1:S93-95.

59. Risal A, Manandhar K, Holen A, Steiner TJ, Linde M. Comorbidities of psychiatric and headache disorders in Nepal: implications from a nationwide population-based study. $J$ Headache Pain 2016;17:45. 



\section{Role of laparoscopic surgery in the treatment of ulcerative colitis; short- and mid-term results}

János Tajti Jr, Zsolt Simonka, Attila Paszt, Szabolcs Ábrahám, Klaudia Farkas, Zoltán Szepes, Tamás Molnár, Ferenc Nagy \& György Lázár

To cite this article: János Tajti Jr, Zsolt Simonka, Attila Paszt, Szabolcs Ábrahám, Klaudia Farkas, Zoltán Szepes, Tamás Molnár, Ferenc Nagy \& György Lázár (2015) Role of laparoscopic surgery in the treatment of ulcerative colitis; short- and mid-term results, Scandinavian Journal of Gastroenterology, 50:4, 406-412, DOI: 10.3109/00365521.2014.985705

To link to this article: https://doi.org/10.3109/00365521.2014.985705

\section{Published online: 23 Jan 2015.}

Submit your article to this journal

Џ Article views: 168

Q View related articles ¿

View Crossmark data ¿

4 Citing articles: 4 View citing articles 


\title{
Role of laparoscopic surgery in the treatment of ulcerative colitis; short- and mid-term results
}

\author{
JÁNOS TAJTI JR ${ }^{1}$, ZSOLT SIMONKA ${ }^{1}$, ATTILA PASZT ${ }^{1}$, SZABOLCS ÁBRAHÁM $^{1}$, \\ KLAUDIA FARKAS ${ }^{2}$, ZOLTÁN SZEPES ${ }^{2}$, TAMÁS MOLNÁR ${ }^{2}$, FERENC NAGY $^{2}$ \& \\ GYÖRGY LÁZÁR ${ }^{1}$
}

\author{
${ }^{1}$ Department of Surgery, University of Szeged, Szeged, Hungary, and ${ }^{2}$ First Department of Internal Medicine, \\ University of Szeged, Szeged, Hungary
}

\begin{abstract}
Objectives. Laparoscopy is used more widely for the surgery of ulcerative colitis. The objective of this study was a comparison of the surgical and 3-year follow-up results of patients treated with conventional and minimally invasive methods. Materials and methods. A total of 45 patients received surgery for ulcerative colitis, 16 as emergency and 29 as elective cases. Laparoscopy was used in 23 and a conventional method in 22 cases. No difference was found between the two groups from the aspects of American Society of Anesthesiologists physical status (ASA) class, mean body mass index (BMI) and age. There were 4 emergency cases in the laparoscopy group, and 12 in the open group. Nineteen elective surgeries were performed in the laparoscopy group, and 10 in the open group. Results. There was no significant difference between the groups as concerns the length of hospital or intensive care unit (ICU) stay, the time to bowel function recovery, but the duration of open surgery was significantly shorter. There was no difference between the groups in the rate of early postoperative complications, whereas among potential late complications, the rates of intestinal obstruction $(8.7 \%$ vs. $45 \%)$ and a septic condition $(0 \%$ vs. $27 \%)$ were significantly lower in the laparoscopy group. There was a significant improvement in the quality of life after surgery in both groups, and better cosmetic results were observed in the laparoscopy group. Conclusion. Laparoscopy can be used for ulcerative colitis both emergency and elective cases, it provides a good quality of life and the mid-term rate of complications is lower as compared with open surgery.
\end{abstract}

Key Words: ileal pouch-anal anastomosis, laparoscopy, proctocolectomy, ulcerative colitis

\section{Introduction}

The epidemiological data reveal that the incidence of ulcerative colitis (UC) is constantly rising, primarily as a consequence of the spreading of the 'Western' lifestyle and urbanization [1]. Its yearly incidence in Europe is $10 / 10^{5}$, and the Hungarian data are not notably different $\left(11.9 / 10^{5}\right) \quad[2,3]$. In 2010 , the inflammatory bowel disease (IBD) registry of five Hungarian centers included 1390 patients, 539 of whom had UC, but since the estimated prevalence of IBD in Hungary is 25,000, these data relate only to the more severe cases [4].
An estimated $25-45 \%$ of patients with UC need surgery at some time $[1,5,6]$. The purpose of the surgical intervention is to remove the affected bowel segment, which can be achieved with either the conventional, open or the laparoscopic technique. Currently, the generally accepted procedure, which has become the gold standard for the surgical treatment of $\mathrm{UC}$, is total proctocolectomy with the creation of an ileal pouch-anal anastomosis (IPAA) [2,7]. This procedure was first performed with a laparoscopic approach by Peters in 1992 [8]. A number of studies have shown that (although the duration of the procedure is longer) laparoscopic surgery has numerous advantages, such as less postoperative pain, a shorter

Correspondence: György Lázár MD, PhD, DSc, Department of Surgery, University of Szeged, 6720 Szeged, Pf. 427, Hungary. Tel: +3662545701.

Fax: +3662545701. E-mail: gylazar@gmail.com 
hospital stay, less time required for recovery of the bowel function, and better cosmetic results. Rather limited experience is available, however, as regard the long-term results of laparoscopic surgery. The objective of this study was a comparison of the surgical and mid-term follow-up results on patients treated for UC with the conventional and the minimally invasive method.

\section{Patients and methods}

Between 1 January 2005 and 31 May 2013, a total of 45 patients ( 27 women, 18 men) underwent surgery for UC in our institution. Patients who had undergone proctocolectomy and colectomy with the creation of a J-pouch were included in the comparison of minimally invasive surgery and the conventional method, with a mean follow-up of 38 (1-92) months. Sixteen $(35.5 \%)$ of the surgical interventions were emergency procedures, while $29(64.5 \%)$ were elective interventions. The laparoscopic technique was used in $23(51.1 \%)$ and the conventional method in $22(48.9 \%)$ cases. The mean age of the patients was $41.29 \pm 14.37$ in the laparoscopy group and $38.91 \pm 12.58$ years in the open surgery group. No difference was found between the two groups in ASA class $(2.19 \pm 0.60$ and $2.14 \pm 0.73, p=0.818)$ or mean BMI $(24.03 \pm 5.15$ and $22.88 \pm 5.74, p=0.490)$ (Table I). The preoperative laboratory data for the patients who participated in emergency surgery indicated an increased inflammatory response. The hematocrit levels ( 31.31 vs. $35.31 \mathrm{~L} / \mathrm{L}, p=0.007$ ) and albumin levels $(28.93$ vs. $39.67 \mathrm{~g} / \mathrm{L}, p<0.001$ ) were significantly lower in the emergency group than in the elective group.

\section{Surgical technique}

Proficient colorectal surgeons operated in both groups. The surgical procedures were performed by three surgeons with about equal rate in the open group, while two surgeons were in the laparoscopic group.

The laparoscopically assisted proctocolectomy + IPAA and the total colectomy + mucous fistula were

Table I. Distribution of Age, American Society of Anesthesiologists physical status (ASA) class and Body Mass Index (BMI) in the laparoscopy and open surgery groups.

\begin{tabular}{lccc}
\hline & $\begin{array}{l}\text { Laparoscopy } \\
(n=23)\end{array}$ & $\begin{array}{l}\text { Open surgery } \\
(n=22)\end{array}$ & \\
\hline Mean age (years) & $41.29 \pm 14.37$ & $38.91 \pm 12.58$ & \\
Mean ASA & $2.19 \pm 0.60$ & $2.14 \pm 0.73$ & $p=0.818$ \\
Mean BMI & $24.03 \pm 5.15$ & $22.88 \pm 5.74$ & $p=0.490$ \\
\hline
\end{tabular}

performed with the use of six or seven ports, depending on the auxiliary incision. The resection of the colon and the creation of the anastomosis and the mucous fistula were performed from the cosmetically favorable Pfannenstiel incision. The J-pouch was created from the terminal ileum with a straight stapler(s), and a double stapler technique was used for the ileoanal anastomosis. The staple line was protected with a loop ileostomy in every case. The pouch created as the second surgical step was also achieved from the Pfannenstiel incision. In the cases involving the conventional method, a midline laparotomy was performed to explore the abdominal cavity, in the lower recess of which the mucous fistula was created; the pouch and the ileoanal anastomosis were created in the same way as during the laparoscopic interventions.

Total proctocolectomy with the creation of a J-pouch and protective loop ileostomy was carried out laparoscopically in 13 cases and with the open technique in 5 cases. The first step was total colectomy with mucous fistula and end ileostomy using the minimally invasive technique in 8 cases and the conventional method in 13 cases.

Conversion from laparoscopy to open surgery was required in 3 cases $(3 / 26,11.53 \%)$, because of massive adhesions during elective surgery ( 1 case) or because of the risk of bowel injury and perforation during emergency surgery ( 2 cases). These cases were excluded from the subsequent analyses.

The distribution of the various surgical procedure is presented in Table II.

The events following the primary surgery were analyzed in two stages: within 30 days (the early period), and after 30 days (the late period). The length of hospitalization, the number of days in the ICU, the time required for recovery of the bowel

Table II. Distribution of surgery.

\begin{tabular}{|c|c|c|c|}
\hline & & $\begin{array}{l}\text { Laparoscopy } \\
(n=23)\end{array}$ & $\begin{array}{l}\text { Open surgery } \\
(n=22)\end{array}$ \\
\hline \multirow[t]{2}{*}{$\begin{array}{l}\text { Two-stage } \\
\text { surgery }\end{array}$} & $\begin{array}{l}\text { Proctocolectomy, } \\
\text { J-pouch, ileostomy }\end{array}$ & $13(56.5 \%)$ & $5(23 \%)$ \\
\hline & Ileostomy closure & 11 & 4 \\
\hline \multirow[t]{3}{*}{$\begin{array}{l}\text { Three-stage } \\
\text { surgery }\end{array}$} & $\begin{array}{l}\text { Total colectomy, } \\
\text { mucous fistula, } \\
\text { end ileostomy }\end{array}$ & $8(34.8 \%)$ & $13(59 \%)$ \\
\hline & $\begin{array}{l}\text { J-pouch creation, } \\
\text { ileostomy }\end{array}$ & 6 & 12 \\
\hline & Ileostomy closure & 5 & 11 \\
\hline \multirow{4}{*}{$\begin{array}{l}\text { One-stage } \\
\text { surgery }\end{array}$} & Rectum extirpation & $2(8.7 \%)$ & 0 \\
\hline & $\begin{array}{l}\text { Proctocolectomy, } \\
\text { end ileostomy }\end{array}$ & 0 & $2(9 \%)$ \\
\hline & $\begin{array}{l}\text { Colectomy, } \\
\text { ileorectostomy }\end{array}$ & 0 & $1(4.5 \%)$ \\
\hline & $\begin{array}{l}\text { Total colectomy, } \\
\text { ileostomy }\end{array}$ & 0 & $1(4.5 \%)$ \\
\hline
\end{tabular}


function and the need for transfusion were recorded. The incidence of complications that could be treated with conservative therapy and those that necessitated surgical intervention, such as ileus, abscess, anal bleeding, fistula, anastomotic stenosis or postoperative hernia, and the rate of mortality were assessed. The patients were monitored for the development of pouchitis and cuffitis, the diagnosis of which was confirmed (besides the clinical symptoms) by endoscopy in every case. The change in the quality of life (the general condition, the body weight and the number of stools daily) and the cosmetic result after the surgical interventions were also assessed. The preoperative and current quality of life of the patients were graded on a scale from 1 to 10 , where 1 was the best and 10 was the worst quality of life. The cosmetic result was assessed with consideration of the length of the surgical incision on a satisfaction scale ranging from 1 to 5 .

\section{Statistics}

The patient population was assessed retrospectively, and the statistical data were processed, and the twosample t-test, the chi-squared test and the MannWhitney test were performed with the SPSS software (IBM SPSS Statistics, Version 20, 2011, Armonk NY, USA).

\section{Results}

\section{Preoperative results}

There was no significant difference in the time (years) from the onset of UC to surgery between the laparoscopic group $(8.71 \pm 5.28)$ and the open surgery group $(8.63 \pm 9.85)$. In the preoperative period, 16 patients $(35.55 \%)$ received biological therapy, with infliximab. The preoperative laboratory test results (white blood cell count, C-reactive protein, hemoglobin, hematocrit and albumin) revealed a significant difference between the two groups only in Creactive protein (Table III). Before the surgical interventions, the mean number of stools daily was $10.78 \pm$

Table III. Mean preoperative laboratory data in the laparoscopy and open surgery groups.

\begin{tabular}{lcclcc}
\hline & $\begin{array}{l}\text { WBC } \\
(\mathrm{G} / \mathrm{L})\end{array}$ & $\begin{array}{l}\mathrm{CRP} \\
(\mathrm{mg} / \mathrm{L})\end{array}$ & $\begin{array}{l}\mathrm{Hgb} \\
(\mathrm{g} / \mathrm{L})\end{array}$ & $\begin{array}{l}\mathrm{Htc} \\
(\mathrm{L} / \mathrm{L})\end{array}$ & $\begin{array}{l}\text { Albumin } \\
(\mathrm{g} / \mathrm{L})\end{array}$ \\
\hline Laparoscopy & 8.33 & 16.79 & 105.43 & 33.81 & 37.79 \\
Open surgery & 9.06 & 47.66 & 109.13 & 33.96 & 33.01 \\
& $p=0.529$ & $p=0.028$ & $p=0.471$ & $p=0.920$ & $p=0.108$ \\
\hline
\end{tabular}

WBC: White Blood Cell; CRP: C-Reactive Protein;

Hgb: Hemoglobin; Htc: Hematocrit
Table IV. Distribution of duration of surgery (minutes).

\begin{tabular}{lrrr}
\hline & \multicolumn{1}{c}{ Laparoscopy } & \multicolumn{1}{l}{ Open surgery } & \\
\hline $\begin{array}{l}\text { Proctocolectomy, } \\
\text { J-pouch, ileostomy }\end{array}$ & $245.42 \pm 51.28$ & $185 \pm 17.80$ & $p=0.040$ \\
$\begin{array}{l}\text { Total colectomy, } \\
\text { mucous fistula, } \\
\text { end ileostomy }\end{array}$ & $187 \pm 32.39$ & $151.67 \pm 23.58$ & $p=0.012$ \\
\hline
\end{tabular}

5.80 and $9.64 \pm 5.38$, respectively, in the two groups. The last colonoscopy report before surgery indicated 30 cases $(66.67 \%)$ of pancolitis, 5 cases $(11.11 \%)$ of left-sided involvement and 10 cases $(22.22 \%)$ of distal involvement.

From the aspect of the duration of surgery, the open method was found to be significantly shorter than the laparoscopic intervention in both the emergency and the elective cases (Table IV).

\section{Postoperative results}

There was no significant difference between the groups in the length of hospital stay, the time to the recovery of the bowel function, the number of days spent in the ICU, or the need for transfusion (Table V). There was no death in the perioperative period in either group.

Complications were classified as early (within 30 days) or late (after 30 days) with regard to their onset after primary surgery. There was no difference ( $p=0.945)$ between the laparoscopy group and the open surgery group in the rate of severe complications that required reoperation. In the laparoscopy group, two patients needed reoperation in the early period because of ileus, an abdominal wall disruption in the area of the mucous fistula that required immediate surgery in one case, and stoma repair was required in one case. In the early period after open surgery, exploration was performed in one patient because of a septic condition, and reoperation was required because of ileus in three cases. Complications

Table V. Immediate postoperative results in the laparoscopy and open surgery groups.

\begin{tabular}{lrrr}
\hline & $\begin{array}{l}\text { Laparoscopy } \\
(n=23)\end{array}$ & $\begin{array}{l}\text { Open surgery } \\
(n=22)\end{array}$ & \\
\hline $\begin{array}{l}\text { Hospital stay (days) } \\
\text { Time to recovery } \\
\text { of bowel function (days) }\end{array}$ & $11.50 \pm 3.85$ & $11.63 \pm 3.79$ & $p=0.914$ \\
$\begin{array}{l}\text { Time spent } \\
\text { in the ICU (days) }\end{array}$ & $2.50 \pm 1$ & $2.09 \pm 0.83$ & $p=0.437$ \\
$\begin{array}{l}\text { Need for blood } \\
\text { transfusion (units) }\end{array}$ & $2.05 \pm 1.77$ & $3.13 \pm 1.90$ & $p=0.57$ \\
\hline
\end{tabular}


Table VI. Early postoperative complications (within 30 days).

\begin{tabular}{|c|c|c|c|}
\hline & Laparoscopy $(n=23)$ & Open surgery $(n=22)$ & \\
\hline Requiring reoperation & $\begin{array}{l}\text { Ileus }(2) \\
\text { Abdominal wall disruption (1) } \\
\text { Stoma repair (1) }\end{array}$ & $\begin{array}{l}\text { Ileus ( } 3 \text { ) } \\
\text { Septic condition (1) }\end{array}$ & \\
\hline Total & $17.4 \%(4 / 23)$ & $18 \%(4 / 22)$ & $p=0.945$ \\
\hline Not requiring reoperation & Subileus (3) & $\begin{array}{l}\text { Subileus (1) } \\
\text { Anal bleeding (1) } \\
\text { Dehydration (1) } \\
\text { Hydrothorax (1) } \\
\text { Urination problems (1) }\end{array}$ & \\
\hline Total & $13 \%(2 / 23)$ & $22 \%(5 / 22)$ & $p=0.396$ \\
\hline
\end{tabular}

necessitating reoperation and other complications are listed in Table VI.

During the follow-up period, wound infection was detected in eight patients (34.8\% of the cases) in the laparoscopy group, and in seven patients $31.8 \%$ of the cases) in the open surgery group; from this respect, there was no significant difference between the groups $(p=0.833)$. Methicillin-resistant staphylococcus aureus infection was confirmed in two patients and one patient, respectively.

During the mean follow-up of 36 months, significantly fewer complications, involving an intestinal obstruction $(p=0.005)$, a septic condition $(p=$ $0.007)$, an anastomotic stenosis, anal bleeding and pouch-vaginal fistula formation $(p=0.001)$, occurred in the laparoscopy group. The rate of development of postoperative hernias was also lower in the laparoscopy group $(8.7 \%$ vs. $18 \%)$, but this difference was not significant statistically $(p=0.349)$ (Table VII).

In the laparoscopy group, surgery was performed because of ileus in one case, and one case of subileus resolved after medical therapy. Abdominal wall reconstruction was carried out electively in two cases because of a hernia in the scar of the previous ileostomy. Endoscopic dilatation was performed in one case of anastomotic stenosis.

In the conventional surgery group, surgery was performed because of ileus as a late complication in four cases. Four perianal abscesses were explored, three of which were treated by Seton drainage. Perianal exploration was needed in one case because of an abscess in the lesser pelvis. In one patient, excision of the pouch was required because of severe pouchitis and a perianal abscess. Rectum extirpation was necessary in two patients because of an impaired sphincter function and anal bleeding. The abdominal wall was reconstructed in four cases because of a postoperative hernia. Two anastomotic stenoses were dilated surgically, while endoscopic dilatation was performed in three patients. Six cases of subileus, one case of anal bleeding and one case of dehydration were resolved through conservative treatment. Two cases of pouchvaginal fistula were observed. During the follow-up, two patients died, as a result of an oral cavity tumor or a cardiorespiratory insufficiency; the causes of death were not related to the UC.

Of the 16 patients treated with infliximab, 4 developed an early postoperative complication.

Table VII. Late postoperative complications (after 30 days).

\begin{tabular}{|c|c|c|c|}
\hline & Laparoscopy $(n=23)$ & Open surgery $(n=22)$ & \\
\hline Septic condition & 0 & $\begin{array}{l}\text { Severe pouchitis }(1) \rightarrow \text { pouch excision } \\
\text { Perianal abscess }(4) \\
\text { Lesser pelvic abscess }(1)\end{array}$ & \\
\hline Total & $0 \%(0 / 23)$ & $27 \%(6 / 22)$ & $p=0.007$ \\
\hline \multicolumn{4}{|l|}{ Intestinal obstruction } \\
\hline Requiring surgical intervention & Ileus (1) & Ileus (4) & \\
\hline Not requiring surgical intervention & Subileus (1) & Subileus (6) & \\
\hline Total & $8.7 \%(2 / 23)$ & $45 \%(10 / 22)$ & $p=0.005$ \\
\hline Postoperative hernia & In the ileostomy scar (2) & In the midline laparotomy scar (4) & \\
\hline Total & $8.7 \%(2 / 23)$ & $18 \%(4 / 22)$ & $p=0.349$ \\
\hline Other & Anastomotic stenosis (1) & $\begin{array}{l}\text { Anastomotic stenosis (5) } \\
\text { Anal bleeding }(2) \rightarrow \text { rectum extirpation (1) } \\
\text { Severe sphincter damage }(1) \rightarrow \text { rectum extirpation } \\
\text { Pouch-vaginal fistula (2) } \\
\text { Dehydration (1) }\end{array}$ & \\
\hline Total & $4.3 \%(1 / 23)$ & $50 \%(11 / 22)$ & $p=0.001$ \\
\hline
\end{tabular}


During the course of the follow-up, there were significantly fewer urgent admissions to a medical unit in the laparoscopy group ( 1 vs. $6, p=0.034$ ).

The clinical symptoms and endoscopic findings confirmed 15 cases of pouchitis, affecting $41 \%$ of the patients with a pouch (6 in the laparoscopic group and 9 in the open surgery group). The inflammation of the pouch was accompanied by cuffitis in 10 cases.

A significant improvement in the quality of life was measured in both groups after the surgery, but there was no significant difference between the two groups.

The postoperative mean number of stools daily at the last medical check-up during the follow-up was $7.83 \pm 3.28$ and $7.81 \pm 3.31$ in the two patient groups. There was therefore a decreasing tendency relative to the preoperative results, which proved to be significant in the laparoscopy group. The preoperative and current body weights indicated an increase in both groups (laparoscopy group: $67.61 \pm 16.19 \mathrm{~kg}$ and $70.83 \pm 18.31 \mathrm{~kg}$, open surgery group: $63.24 \pm$ $16.15 \mathrm{~kg}$ and $73.68 \pm 12.73 \mathrm{~kg}$ ), which was significant in the open surgery patient population (Table VIII).

The mean length of the midline laparotomy incision in the open surgery group was $13.9 \pm 7 \mathrm{~cm}$, and the mean length of the Pfannenstiel incision in the laparoscopy group was $10.5 \pm 3.5 \mathrm{~cm}$. From the aspect of the cosmetic result, the patients graded their satisfaction on a five-item scale (not at all satisfied slightly satisfied - moderately satisfied - rather satisfied - very satisfied), which demonstrated that those who had undergone open surgery were on average 'rather satisfied', while the laparoscopic patients were on average 'very satisfied'.

\section{Discussion}

This study has confirmed that laparoscopic surgical treatment can be used safely for both emergency and elective cases in UC patients. There was no difference between the open surgery and laparoscopy groups as concerns the length of the hospital stay, the number of days spent in the ICU, the blood loss, the time required for the recovery of the bowel function and the number of perioperative complications, but the duration of laparoscopic surgery proved to be significantly longer. The quality of life of the patients improved significantly in both groups. As differences, the rates of intestinal obstruction, septic and other complications, and medical re-hospitalization were significantly higher among the patients who had undergone open surgery, and the laparoscopic patients on average reported a higher level of satisfaction with the cosmetic result.

The treatment of UC is primarily based on medical/ biological therapy. A surgical intervention is considered in the event of the failure of the conservative therapy and the emergence of severe complications of the disease. Proctocolectomy and IPAA creation are adequate alternatives in the surgical treatment of UC, and are currently the most frequently chosen types of surgery $[2,9]$.

The minimally invasive technique has also gained popularity in the treatment of UC and, similarly to the open technique, can be used safely [10]. Its advantages include a shorter hospital stay, less postoperative pain, a shorter time for recovery of the bowel function and a better cosmetic result, but it has the disadvantage of a longer duration of surgery [11]. The current data available in a large international database confirm better rates of both morbidity and mortality in the minimally invasive patient group [12].

Our own results indicate that, other than the cosmetic results, laparoscopic surgery has no clear advantage in the perioperative period. However, the duration of surgery differed significantly in the two patient groups: the laparoscopic interventions took longer to complete. There was no measurable difference in the length of hospital stay, the time until the recovery of the bowel function, the number of days spent in the ICU, the postoperative need for blood transfusion or the wound healing problems. Similarly, Fajardo et al. did not observe a difference in the rate of morbidity during the short-term follow-up of twostage laparoscopic and open IPAA surgery [13]. A meta-analysis published in 2010 did not find a difference between the conventional open and the minimally invasive procedure from the aspect of complications such as a lesser pelvic abscess,

Table VIII. Pre- and postoperative quality of life, number of stools daily and body weight in the laparoscopy and open surgery groups.

\begin{tabular}{llccc}
\hline & & Preoperative & \multicolumn{1}{c}{ Current } \\
\hline Quality of life & Laparoscopy $(n=23)$ & $8.88 \pm 1.5$ & $2.38 \pm 2.03$ & $p<0.0001$ \\
& Open surgery $(n=22)$ & $8.8 \pm 1.74$ & $2.6 \pm 2.03$ & $p=0.001$ \\
Number of stools daily & Laparoscopy $(n=23)$ & $10.78 \pm 5.80$ & $7.83 \pm 3.28$ & $p=0.061$ \\
& Open surgery $(n=22)$ & $9.64 \pm 5.38$ & $7.81 \pm 3.31$ & $p=0.238$ \\
Body weight & Laparoscopy $(n=23)$ & $67.61 \pm 16.19$ & $70.83 \pm 18.31$ & $p=0.554$ \\
& Open surgery $(n=22)$ & $63.24 \pm 16.15$ & $73.68 \pm 12.73$ & $p=0.030$ \\
\hline
\end{tabular}


anastomotic leakage and ileus [14]. Similarly, a recent randomized study likewise confirmed only the cosmetic advantage of the laparoscopic method [15].

Our study led to the finding that the minimally invasive method does not have an advantage as concerns the early complications, but it is demonstrably more advantageous in terms of the incidence of late complications. The rate of medical re-hospitalization was significantly lower in the laparoscopy group $(4.34 \%$ vs. $27 \%)$. Similarly, the rates of intestinal obstruction $(8.7 \%$ vs. $45 \%)$, septic condition $(0 \%$ vs. $27 \%)$ and other complications $(4.3 \%$ vs. $50 \%)$ were also significantly lower in the group of patients who had undergone laparoscopic surgery.

The obvious explanation for the higher rate of hernias in the open surgery group $(8.7 \%$ vs. $18 \%)$ is the more extensive entry opening. The higher rate of ileus and subileus in the open surgery group is probably caused by the higher level of surgical trauma and the adhesions due to the wound surface. Hull et al. observed significantly more cases of adhesion after open IPAA surgery, and a similar result was reported by Indar et al. $[16,17]$. The research by Bartels et al. revealed that the incidence of adhesions and postoperative hernias was significantly higher following emergency open colectomies performed because of UC [18]. In a US study, however, the incidence of small bowel obstruction after IPAA was not different when the laparoscopic technique was employed [19].

In several studies, prior biological therapy was considered to have a negative effect on the results of the surgical treatment in UC [20,21], although this is not supported by other observations [22-24] or the most recent case-matched study [25]. Our study indicated only four cases of an early postoperative complication among the 16 patients who had received infliximab treatment and therefore suggests that prior biological therapy is not associated with a higher rate of complications.

The most common complication in the long term after IPAA surgery performed because of UC is pouchitis. A total of 15 cases of pouchitis were recorded in our study, corresponding to $41 \%$ of the patients with a pouch; there was no difference between the groups. A Swedish study found chronic pouchitis to be the main functional issue during a long-term follow-up after IPAA surgery [26]. The exact etiology of pouchitis is still unknown; no independent risk factor has been recognized. The study by Kalkan et al. pointed to the fulminant colitis leading to the surgery and the steroid dependence as the possible causes of pouchitis, whereas Uchino et al. were of the opinion that a toxic megacolon and the onset of UC before the age of 26 years may predispose to chronic pouchitis $[27,28]$.
In the course of the follow-up, significant improvements were noted in the number of stools daily, the body weight and the quality of life, whereas Fichera et al. did not find a difference between laparoscopy and open IPAA surgery from the aspect of the number of stools daily postoperatively and a similar result was reported from an English study $[7,29]$. Likewise, Polle et al. did not detect a difference in the quality of life, the morbidity rate or the functional results following open and laparoscopic proctocolectomies, but confirmed a better cosmetic result among laparoscopic female patients [30]. Many publications have reported a better postoperative quality of life following IPAA surgery [31-37].

Our study clearly demonstrates that minimally invasive procedures can be used safely for the surgical treatment of UC in both emergency and elective cases, and these are cosmetically advantageous procedures that are expected to result in a considerably improved quality of life.

Moreover, it is important to emphasize that lower rates of postoperative hernia and ileus are to be expected in the long term after laparoscopic surgery.

\section{Acknowledgements}

The authors thank David Durham from England for linguistic correction of the manuscript.

Declaration of interest: The authors report no conflicts of interest. The authors alone are responsible for the content and writing of the paper.

\section{References}

[1] Ágota Kovács LL. Gyulladásos bélbetegségek, medicina. Medicina, Budapest; 2011.

[2] Bennis M, Tiret E. Surgical management of ulcerative colitis. Langenbecks Arch Surg 2012;397:11-17.

[3] Lakatos L, Kiss LS, David G, Pandur T, Erdelyi Z, Mester $G$, et al. Incidence, disease phenotype at diagnosis, and early disease course in inflammatory bowel diseases in Western Hungary, 2002-2006. Inflamm Bowel Dis 2011;17: 2558-65.

[4] Miheller P, Nagy F, Palatka K, Altorjay I, Horvath G, Lorinczy $\mathrm{K}$, et al. [Hungarian data on inflammatory bowel diseases: analytical data on ulcerative colistis]. Orv Hetil 2012;153:702-12.

[5] Ferrante M, Declerck S, De Hertogh G, Van Assche G, Geboes K, Rutgeerts P, et al. Outcome after proctocolectomy with ileal pouch-anal anastomosis for ulcerative colitis. Inflamm Bowel Dis 2008;14:20-8.

[6] Roses RE, Rombeau JL. Recent trends in the surgical management of inflammatory bowel disease. World J Gastroenterol 2008;14:408-12.

[7] Fichera A, Silvestri MT, Hurst RD, Rubin MA, Michelassi F. Laparoscopic restorative proctocolectomy 
with ileal pouch anal anastomosis: a comparative observational study on long-term functional results. J Gastrointest Surg 2009; 13:526-32.

[8] Peters WR. Laparoscopic total proctocolectomy with creation of ileostomy for ulcerative colitis: report of two cases. J Laparoendosc Surg 1992;2:175-8.

[9] Biondi A, Zoccali M, Costa S, Troci A, Contessini-Avesani E, Fichera A. Surgical treatment of ulcerative colitis in the biologic therapy era. World J Gastroenterol 2012;18: 1861-70.

[10] Sica GS, Biancone L. Surgery for inflammatory bowel disease in the era of laparoscopy. World J Gastroenterol 2013; 19:2445-8.

[11] Zoccali M, Fichera A. Minimally invasive approaches for the treatment of inflammatory bowel disease. World J Gastroenterol 2012;18:6756-63.

[12] Causey MW, Stoddard D, Johnson EK, Maykel JA, Martin MJ, Rivadeneira D, et al. Laparoscopy impacts outcomes favorably following colectomy for ulcerative colitis: a critical analysis of the ACS-NSQIP database. Surg Endosc 2013;27:603-9.

[13] Fajardo AD, Dharmarajan S, George V, Hunt SR, Birnbaum EH, Fleshman JW, et al. Laparoscopic versus open 2-stage ileal pouch: laparoscopic approach allows for faster restoration of intestinal continuity. J Am Coll Surg 2010;211:377-83.

[14] Wu XJ, He XS, Zhou XY, Ke J, Lan P. The role of laparoscopic surgery for ulcerative colitis: systematic review with meta-analysis. Int J Colorectal Dis 2010;25:949-57.

[15] Schiessling S, Leowardi C, Kienle P, Antolovic D, Knebel P, Bruckner $\mathrm{T}$, et al. Laparoscopic versus conventional ileoanal pouch procedure in patients undergoing elective restorative proctocolectomy (LapConPouch Trial)-a randomized controlled trial. Langenbecks Arch Surg 2013;398:807-16.

[16] Hull TL, Joyce MR, Geisler DP, Coffey JC. Adhesions after laparoscopic and open ileal pouch-anal anastomosis surgery for ulcerative colitis. Br J Surg 2012;99:270-5.

[17] Indar AA, Efron JE, Young-Fadok TM. Laparoscopic ileal pouch-anal anastomosis reduces abdominal and pelvic adhesions. Surg Endosc 2009;23:174-7.

[18] Bartels SA, Vlug MS, Henneman D, Ponsioen CY, Tanis PJ, Bemelman WA. Less adhesiolysis and hernia repair during completion proctocolectomy after laparoscopic emergency colectomy for ulcerative colitis. Surg Endosc 2012;26: 368-73.

[19] Dolejs S, Kennedy G, Heise CP. Small bowel obstruction following restorative proctocolectomy: affected by a laparoscopic approach? J Surg Res 2011;170:202-8.

[20] Mor IJ, Vogel JD, da Luz Moreira A, Shen B, Hammel J, Remzi FH. Infliximab in ulcerative colitis is associated with an increased risk of postoperative complications after restorative proctocolectomy. Dis Colon Rectum 2008;51:1202-7. discussion 1207-1210.

[21] Selvasekar CR, Cima RR, Larson DW, Dozois EJ, Harrington JR, Harmsen WS, et al. Effect of infliximab on short-term complications in patients undergoing operation for chronic ulcerative colitis. J Am Coll Surg 2007;204:95662.discussion 962-953.

[22] Ferrante M, D'Hoore A, Vermeire S, Declerck S, Noman M, Van Assche G, et al. Corticosteroids but not infliximab increase short-term postoperative infectious complications in patients with ulcerative colitis. Inflamm Bowel Dis $2009 ; 15: 1062-70$.
[23] Kunitake H, Hodin R, Shellito PC, Sands BE, Korzenik J, Bordeianou L. Perioperative treatment with infliximab in patients with Crohn's disease and ulcerative colitis is not associated with an increased rate of postoperative complications. J Gastrointest Surg 2008;12:1730-6.discussion 1736-1737.

[24] Schluender SJ, Ippoliti A, Dubinsky M, Vasiliauskas EA, Papadakis KA, Mei L, et al. Does infliximab influence surgical morbidity of ileal pouch-anal anastomosis in patients with ulcerative colitis? Dis Colon Rectum 2007;50:1747-53.

[25] Coquet-Reinier B, Berdah SV, Grimaud JC, Birnbaum D, Cougard PA, Barthet M, et al. Preoperative infliximab treatment and postoperative complications after laparoscopic restorative proctocolectomy with ileal pouch-anal anastomosis: a case-matched study. Surg Endosc 2010;24:1866-71.

[26] Karlbom U, Lindfors A, Pahlman L. Long-term functional outcome after restorative proctocolectomy in patients with ulcerative colitis. Colorectal Dis 2012;14:977-84.

[27] Kalkan IH, Dagli U, Onder FO, Tunc B, Oztas E, Ulker A, et al. Evaluation of preoperative predictors of development of pouchitis after ileal-pouch-anastomosis in ulcerative colitis. Clin Res Hepatol Gastroenterol 2012;36:622-7.

[28] Uchino M, Ikeuchi H, Matsuoka H, Bando T, Takesue Y, Tomita N. Clinical features and management of pouchitis in Japanese ulcerative colitis patients. Surg Today 2013;43: 1049-57.

[29] Singh P, Bhangu A, Nicholls RJ, Tekkis P. A systematic review and meta-analysis of laparoscopic vs open restorative proctocolectomy. Colorectal Dis 2013;15:e340-51.

[30] Polle SW, Dunker MS, Slors JF, Sprangers MA, Cuesta MA, Gouma DJ, et al. Body image, cosmesis, quality of life, and functional outcome of hand-assisted laparoscopic versus open restorative proctocolectomy: long-term results of a randomized trial. Surg Endosc 2007;21:1301-7.

[31] Andersson $T$, Lunde OC, Johnson E, Moum T, Nesbakken A. Long-term functional outcome and quality of life after restorative proctocolectomy with ileo-anal anastomosis for colitis. Colorectal Dis 2011;13:431-7.

[32] Brandsborg S, Tottrup A, Nicholls J, Laurberg S. Restorative proctocolectomy in patients with ulcerative colitis: a crosssectional Danish population study on function and quality of life. Colorectal Dis 2013;15:e453-61.

[33] Heikens JT, de Vries J, Goos MR, Oostvogel HJ, Gooszen HG, van Laarhoven CJ. Quality of life and health status before and after ileal pouch-anal anastomosis for ulcerative colitis. Br J Surg 2012;99:263-9.

[34] Heikens JT, de Vries J, van Laarhoven CJ. Quality of life, health-related quality of life and health status in patients having restorative proctocolectomy with ileal pouch-anal anastomosis for ulcerative colitis: a systematic review. Colorectal Dis 2012;14:536-44.

[35] Holubar S, Hyman N. Continence alterations after ileal pouch-anal anastomosis do not diminish quality of life. Dis Colon Rectum 2003;46:1489-91.

[36] Larson DW, Davies MM, Dozois EJ, Cima RR, Piotrowicz K, Anderson K, et al. Sexual function, body image, and quality of life after laparoscopic and open ileal pouch-anal anastomosis. Dis Colon Rectum 2008;51:392-6.

[37] Leowardi C, Hinz U, Tariverdian M, Kienle P, Herfarth C, Ulrich A, et al. Long-term outcome 10 years or more after restorative proctocolectomy and ileal pouch-anal anastomosis in patients with ulcerative colitis. Langenbecks Arch Surg 2010;395:49-56. 



\title{
Colitis ulcerosa
}

\section{minimálisan invazív sebészi kezelése - hosszú távú eredmények}

\author{
Tajti János jr. dr. ${ }^{1}$ - Simonka Zsolt dr. ${ }^{1}$ - Paszt Attila dr. ${ }^{1}$ \\ Ábrahám Szabolcs dr. ${ }^{1}$. Farkas Klaudia dr. ${ }^{2}$ - Szepes Zoltán dr. ${ }^{2}$ \\ Molnár Tamás dr. ${ }^{2}$ - Nagy Ferenc dr. ${ }^{2}$ - Lázár György dr. ${ }^{1^{*}}$ \\ Szegedi Tudományegyetem, Általános Orvostudományi Kar, 'Sebészeti Klinika, \\ ${ }^{2}$ I. Belgyógyászati Klinika, Szeged
}

\begin{abstract}
Bevezetés: A colitis ulcerosa sebészi kezelésében egyre szélesebb körben alkalmazzák a laparoszkópos technikát, azonban hosszú távú magyarországi eredményekkel eddig még nem rendelkeztünk. Célkitüzés: A szerző́k célja a hagyományos és a minimálisan invazív módszerrel operált betegek mútéti és 47,8 hónapos utánkövetési eredményeinek összehasonlítása. Módszer: 2005. január 1. és 2014. december 31. között összesen 56 beteg került mútétre colitis ulcerosa diagnózissal, akik közül 20-at sürgósséggel, 36-ot tervezetten mútöttek. Laparoszkópos technikával 33, nyitottan 23 mútétet végeztek. Eredmények: A perioperatív időszakban az ápolási idő, passzázsmegindulás, az intenzív osztályos és transzfúziós igény és szövődmények terén a csoportok között különbséget nem észleltek. Hosszú távú szövődmények tekintetében az intestinalis obstrukció, a szeptikus állapot és az egyéb komplikációk előfordulása szignifikánsan alacsonyabb volt a laparoszkópos mútéten átesett betegek csoportjában. Mindkét csoport életminőségében szignifikáns javulást tapasztaltak a mútétet követően. Következtetések: A colitis ulcerosa kezelésében a laparoszkópos módszer biztonságosan alkalmazható, amely jó életminőséget, kedvezőbb kozmetikai eredményt biztosít és hosszú távon alacsonyabb a szövődmények aránya a nyitott mútétekkel összehasonlítva. Orv. Hetil., 2015, 156(39), $1585-1592$.
\end{abstract}

Kulcsszavak: colitis ulcerosa, laparoszkópia, ileoanalis anastomosis, J-pouch

\section{Minimally invasive surgical treatment of ulcerative colitis - long-term results}

\begin{abstract}
Introduction: For the surgical treatment of ulcerative colitis, laparoscopy is used more widely, but less data are available on long-term results in Hungary. Aim: The aim of the authors was to compare the mean 47.8-month follow-up results of patients treated with conventional and minimally invasive surgical methods. Method: Between January 1 , 2005 and December 31, 2014, 56 patients were treated with surgery (20 emergencies, and 36 elective cases). Laparoscopy was used in 33 and conventional method in 23 cases. Results: There was no difference between the two groups in hospital and intensive care unit stay, bowel function recovery, need for transfusion, and complications during the perioperative period. Regarding long-term complications, the occurrence of intestinal obstruction, septic condition and other complications were significantly fewer in the laparoscopy group. The quality of life improved in both groups after the surgery. Conclusions: Laparoscopy can be used safely; it provides good quality of life and better cosmetic results, and the long-term rate of complications is lower as compared to open surgery.
\end{abstract}

Keywords: ulcerative colitis, laparoscopy, ileo-pouch anal anastomosis, J-pouch

Tajti, J. Jr., Simonka, Zs., Paszt, A., Ábrahám, Sz., Farkas, K., Szepes, Z., Molnár, T., Nagy, F., Lázár, Gy. [Minimally invasive surgical treatment of ulcerative colitis - long-term results]. Orv. Hetil., 2015, 156(39), 1585-1592.

(Beérkezett: 2015. július 10.; elfogadva: 2015. augusztus 13.) 


\section{Rövidítések}

ASA $=$ American Society of Anaesthesiologists; BMI = testtömegindex; $\mathrm{CRP}=\mathrm{C}$-reaktív protein $\mathrm{CU}=$ colitis ulcerosa; FVS $=$ fehérvérsejt; Hgb = hemoglobin; Htk = hematokrit; $\mathrm{IBD}=($ inflammatory bowel disease $)$ gyulladásos bélbetegség; IPAA $=$ ileopouch-analis anastomosis

A minimálisan invazív sebészeti beavatkozás napjainkban egyre nagyobb teret nyer, amely módszer a vastagbélsebészetben, így a gyulladásos bélbetegségek (inflammatory bowel disease - IBD) kezelésében is megjelent. Az első laparoszkópos vastagbélmütét Moise Jacobs nevéhez füződik, aki 1990-ben jobb oldali hemicolectomiát végzett minimálisan invazív módon [1]. Epidemiológiai adatok szerint a colitis ulcerosában (CU) szenvedő betegek száma emelkedik, aminek hátterében genetikai és számos környezeti hatást igazoltak. Hazánkban Mibeller és mtsai az IBD gyakoriságát 2010-ben 25 000-re becsülték [2]. A széles spektrumú gyógyszeres, valamint biológiai terápiának köszönhetően a CU konzervatív kezeléssel sokáig egyensúlyban tartható, azonban az erre nem reagáló, gyakori relapsusokkal járó, illetve szövődményes esetekben sebészeti beavatkozás válik szükségessé, amelynek célja a „célszerv”, a vastagbél eltávolítása. Napjainkban totális proctocolectomia, ileoanalis anastomosissal történő J-pouch (IPAA) kialakítása a leginkább elfogadott eljárás, amelynek laparoszkópos kivitelezéséról elsőként Peters munkacsoportja számolt be a kilencvenes évek elején $[3,4]$.

Az eddigi adatok igazolták, hogy a CU sebészetében a hagyományos mưtéti technikával szemben a minimálisan invazív módszer előnye a rövidebb ápolási idő, a kisebb posztoperatív fájdalom, a gyors passzázsrendeződés és a kedvező kozmetikai eredmény a hosszabb mútéti idővel szemben [5].

A CU minimálisan invazív kezelését illetőn magyarországi utánkövetési adatokkal limitált számban rendelkezünk. Vizsgálatunk célja a nyitott és a laparoszkópos módszerrel operált betegek perioperatív és hosszú távú eredményeinek összehasonlítása.

\section{Módszer és sebészi technika}

2005. január 1. és 2014. december 31. között összesen 56 betegnél (31 nő, 25 férfi) végeztünk mútétet $\mathrm{CU}$ diagnózisával. Vizsgálatunkba a klinikailag, radiológiailag, endoszkóppal és szövettanilag igazolt CU-ban szenvedó betegek kerültek. Az irradiáció okozta vastagbélgyulladás, az álhártyás colitis, a CU talaján kialakult tumoros propagáció eseteitól, valamint a laparoszkópos kezdést követő konvertált beavatkozásoktól $(3 / 36,8,33 \%$, adhéziók és bélsérülés veszélye) eltekintettünk.

A primer mütétek utáni időszakot 30 napon belüli, korai és 30 napon túli, késői időszakra bontva elemeztük. Regisztráltuk az ápolási időt, intenzív osztályon töltött napok számát, a passzázsmegindulást és transzfúziós igényt. Vizsgáltuk a konzervatív terápiával kezelhető és a mútéti beavatkozást igénylő szövődményeket, komplikációkat, mint például ileus, tályog, per anum vérzés, fistula, anastomosisszúkület, posztoperatív sérv és mortalitás előfordulását. Kerestük a pouchitis és cuffitis megjelenését, amelyek diagnózisát minden esetben a klinikai tünetek mellett endoszkópos kontroll is igazolta. Vizsgáltuk a mütéti beavatkozásokat követő életminőségbeli változást (általános állapot, testsúly, napi székletszám). A betegek mútét előtti és jelenlegi életminőségének vizsgálatát 1-10-ig terjedő skála alapján hasonlítottuk össze.

A betegek adatainak vizsgálatát retrospektív módszerrel, a statisztika feldolgozását, kétmintás t-próbát, $\chi^{2}$ próbát és Mann-Whitney-tesztet végeztünk SPSS programmal (IBM SPSS Statistics, Version 22, 2014, Chicago, IL, Amerikai Egyesült Államok).

Laparoszkóposan asszisztált mütétekhez 6-7 portot használtunk, míg a vastagbél reszekcióját Pfannenstielmetszésből végeztük. A J-pouch kialakításához, a körülbelül $15 \mathrm{~cm}$ hosszúságú terminális ileumból, egyenes vágó-varró gépet, az ileoanalis anastomosis elkészítéséhez kettősstapler-technikát alkalmaztunk. A varratsort kacsileostomával tehermentesítettük. Hagyományos módszer esetén median laparotomiából exploráltuk a hasüreget.

\section{Eredmények}

Utánkövetésünk átlagosan 47,8 (3-111) hónapig tartott. Az 56 eset közül laparoszkópos technikával 33 $(58,9 \%)$, hagyományos módszerrel $23(41,1 \%)$ mútét történt, az indikációt tekintve $20(35,7 \%)$ sürgősséggel, míg $36(64,3 \%)$ tervezett úton.

Az akut mútéti beavatkozásokat terápiarefrakter, septicotoxicus állapot miatt végeztük, amelyhez 4 esetben vérzés, 1-1 esetben perforáció, illetve ileus és 2 betegnél súlyos malnutritio is társult. Az elektív beavatkozásokat konzervatív kezeléssel egyensúlyban nem tartható állapot miatt végeztük.

\section{Perioperatív eredmények}

A betegek átlagéletkora a laparoszkópos és a nyitott csoportban $45,09 \pm 14,49$, illetve $38,26 \pm 12,68$ év volt. A két csoportban a testtömegindexet (BMI) $(22,76 \pm 4,68$ és $22,59 \pm 5,94)$ és az American Society of Anaesthesiologists (ASA) -beosztást $(2,27 \pm 0,57$ és $2,05 \pm 0,68)$ illetően különbséget nem találtunk, a betegség diagnosztizálásától a mútéti beavatkozásig átlagosan 9,05 7,86 és $8,26 \pm 9,93$ év telt el. Áttekintve az extraintestinalis manifesztációkat, $5(8,9 \%)$ esetben találtunk szem-, 7 (12,5\%) betegnél bőrérintettséget, $18(32,14 \%)$ beteg szenvedett csont- és ízületi fájdalomtól. $3(5,3 \%)$ betegnél merült fel primer szklerotizáló cholangitis lehetősége, 7 (12,5\%) esetben zajlott korábban mélyvénás trombózis és 2 betegnél volt tüdőt érintő gümőkór $(3,57 \%)$, míg az anamnézisekben $2(3,57 \%)$ tumoros megbetegedés (vese- és 
szájüregi érintettség) is szerepelt. Betegeink között nem ismert aktív dohányzó, csupán 8 esetben igazolódott korábbi dohányzás, valamint 2 esetben szerepelt appendectomia a kórtörténetben. Preoperatív laboreredményeket (fehérvérsejt, C-reaktív protein, hemoglobin, hematokrit, albumin) áttekintve a nyitott csoportban a gyulladásos markerek értéke szignifikánsan magasabbnak bizonyult. Utóbbi eredmény a fokozott szeptikus állapottal járó akut mútétek magasabb arányával magyarázható a hagyományos módszerrel operált betegcsoportban $(56,52 \%$ vs. $21,21 \%)$. A mútét előtti időszakban 23 (41,07\%) beteg részesült biológiai, infliximabterápiában. A betegek perioperatív eredményeit az 1. táblázat foglalja össze.

1. táblázat | Perioperatív eredmények és mútét előtti laboratóriumi vizsgálatok

\begin{tabular}{llll}
\hline & $\begin{array}{l}\text { Laparoszkópos } \\
(\mathrm{n}=33)\end{array}$ & $\begin{array}{l}\text { Nyitott } \\
(\mathrm{n}=23)\end{array}$ & \\
\hline Életkor (év) & $45,09 \pm 14,49$ & $38,26 \pm 12,68$ & $\mathrm{p}=0,074$ \\
ASA-beosztás & $2,27 \pm 0,57$ & $2,05 \pm 0,68$ & $\mathrm{p}=0,125$ \\
BMI & $22,76 \pm 4,68$ & $22,59 \pm 5,94$ & $\mathrm{p}=0,906$ \\
Ápolási idő (nap) & $10,75 \pm 3,61$ & $11,39 \pm 3,78$ & $\mathrm{p}=0,528$ \\
$\begin{array}{l}\text { Passzázsmegindulás } \\
\text { (nap) }\end{array}$ & $1,32 \pm 0,66$ & $1,63 \pm 0,68$ & $\mathrm{p}=0,129$ \\
$\begin{array}{l}\text { Intenzív osztályon } \\
\text { töltött idő (nap) }\end{array}$ & $2,4 \pm 0,89$ & $2,10 \pm 0,87$ & $\mathrm{p}=0,545$ \\
Vérigény (egység) & $2,18 \pm 2,0$ & $2,73 \pm 1,7$ & $\mathrm{p}=0,283$ \\
FVS $(\mathrm{G} / \mathrm{l})$ & $8,5 \pm 3,11$ & $10,42 \pm 3,36$ & $\mathrm{p}=0,032$ \\
CRP (mg/l) & $23,29 \pm 36,18$ & $51,51 \pm 57,62$ & $\mathrm{p}=0,031$ \\
Albumin $(\mathrm{g} / \mathrm{l})$ & $37,8 \pm 7,66$ & $33,46 \pm 7,61$ & $\mathrm{p}=0,096$ \\
Hgb $(\mathrm{g} / \mathrm{l})$ & $109,72 \pm 19,48$ & $109,52 \pm 18,94$ & $\mathrm{p}=0,969$ \\
Htk $(1 / 1)$ & $34,27 \pm 5$ & $33,95 \pm 5,8$ & $\mathrm{p}=0,828$ \\
\hline
\end{tabular}

ASA $=$ American Society of Anaesthesiologists; BMI = testtömegindex; FVS = fehérvérsejt; CRP = C-reaktív protein; $\mathrm{Hgb}=$ hemoglobin; Htk $=$ hematokrit

Totális proctocolectomiát végeztünk J-pouch kialakításával és protektív loop ileostomával laparoszkóposan 21 , nyitott technikával 5 esetben. A mútéti időtartam $221 \pm 51,49$, illetve $185 \pm 17,79$ perc volt. Utánkövetésünk során az ileostoma 17 , illetve 5 esetben került zárásra, viselése a két csoportban átlagosan 3,8 és 4,4 hónapig tartott.

Első lépcsőként totális colectomiát készítettünk nyákfistulával és végileostomával minimálisan invazív módon 9, hagyományos módszerrel 14 esetben, a beavatkozások $186,88 \pm 30,11$, valamint $151,54 \pm 22,58$ perc hosszúságúak voltak, amely utóbbi adat szignifikánsan ( $\mathrm{p}=$

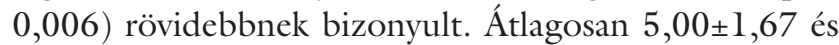
$5,15 \pm 3,02$ hónap elteltével végeztük el másodülésben a pouchmútéteket, amelyek száma 6 , illetve 13 volt. Utolsó lépésként az ileostomát 6 , illetve 12 esetben zártuk, a primer beavatkozástól számolva 7,83 és 9,25 hónapot követően.

A laparoszkópos csoportban a Crohn-betegségre utaló szövettani lelet miatt 2 esetben a nyákfistulát ileorectostomiává alakítottuk. Laparoszkópos technikával 3 rectumexstirpatiót, hagyományos módszerrel 1 colectomiát ileorectalis anastomosissal, 2 totális proctocolectomiát végileostomával és 1 totális colectomiát végeztünk ileostomával. A mútéti típusok eloszlását a 2. táblázatban foglaltuk össze.

2. táblázat | Mútéti típusok és mútéti időtartamok

\begin{tabular}{|c|c|c|c|}
\hline & & $\begin{array}{l}\text { Laparoszkópos } \\
(\mathrm{n}=33)\end{array}$ & $\begin{array}{l}\text { Nyitott } \\
(\mathrm{n}=23)\end{array}$ \\
\hline \multirow[t]{2}{*}{$\begin{array}{l}\text { Kétszakaszos } \\
\text { mútétek }\end{array}$} & $\begin{array}{l}\text { Proctocolectomia, } \\
\text { J-pouch ileostoma }\end{array}$ & $21(63,6 \%)$ & $5(21,7 \%)$ \\
\hline & $\begin{array}{l}\text { Mütéti idő (perc) } \\
\mathrm{p}=0,187\end{array}$ & $221 \pm 51,49$ & $185 \pm 17,79$ \\
\hline \multirow[t]{2}{*}{$\begin{array}{l}\text { Három- } \\
\text { szakaszos } \\
\text { mútétek }\end{array}$} & $\begin{array}{l}\text { Totális } \\
\text { colectomia, } \\
\text { nyákfistula, } \\
\text { végileostoma }\end{array}$ & $9(27,2 \%)$ & $14(60,8 \%)$ \\
\hline & $\begin{array}{l}\text { Mütéti idő (perc) } \\
\mathrm{p}=0,006\end{array}$ & $186,88 \pm 30,11$ & $151,54 \pm 22,58$ \\
\hline \multirow{4}{*}{$\begin{array}{l}\text { Egyéb } \\
\text { mútétek }\end{array}$} & Rectumexstirpatio & $3(9 \%)$ & 0 \\
\hline & $\begin{array}{l}\text { Proctocolectomia, } \\
\text { végileostoma }\end{array}$ & 0 & $2(8,6 \%)$ \\
\hline & $\begin{array}{l}\text { Colectomia, } \\
\text { ileorectostoma }\end{array}$ & 0 & $1(4,3 \%)$ \\
\hline & $\begin{array}{l}\text { Totális } \\
\text { colectomia, } \\
\text { ileostoma }\end{array}$ & 0 & $1(4,3 \%)$ \\
\hline
\end{tabular}

A két beteganyag ápolási idejében, intenzív osztályon eltöltött napok számában, transzfúziós igényében, valamint az első széklet megjelenéséig eltelt időben mérhető különbséget nem találtunk (1. táblázat).

A kórszövettani feldolgozás az esetek nagy részében (39) súlyos gyulladást véleményezett. Aktív volt a folyamat 8 esetben, idült gyulladás jelei 4 mintában látszottak. Két betegnél felszínes gyulladást és 1 inaktív formát írtak le, valamint 2 esetben a teljes colont érintő Crohnbetegséget is diagnosztizáltak. Az utóbbi két betegnél primer mútétként laparoszkópos totális colectomiát végeztünk nyákfistulával, majd - tekintettel a patológiai leletre - a tápcsatorna folytonosságát ileorectostomiával állítottuk helyre.

\section{Szövődmények}

A primer mútétekhez képest korai (30 napon belüli) és késői (30 napon túli) csoportra osztva vizsgáltuk a szövődmények, komplikációk megjelenését. A korai időszakban megjelenő szövődményeket reoperációtól 
függően két csoportba osztottuk. A laparoszkópos beavatkozásokat követően 5 esetben kényszerültünk ismételt mútétre: 2 esetben ileus miatti adhaesiolysis, 2 betegnél ileostoma korrekciója és l esetben a nyákfistula mentén megjelenő hasfali szétválás miatt történt resutura. Konzervatív kezeléssel 3 betegnek sikerült rendezni subileusos állapotát, alhasi tályog miatt 1 esetben történt ultrahangvezérelt intervenciós drenálás, valamint 1 vérzéssel járó súlyos pouchitis oldódott meg lokális kezelésre. A hagyományos módon operált csoportban a korai időszakban szeptikus állapot miatt 1 betegnél végeztünk exploratiót, 3 esetben történt reoperáció ileus miatt. Míg egyéb, hydrothorax, per anum vérzés, subileus, exsiccosis és vizelési panaszok kapcsán nem mưtéti kezelés volt sikeres. A 23, korábban infliximabterápiában részesült beteg közül 6 esetében alakult ki korai szövődmény. A korai időszakban reoperációt igénylő és az egyéb szövődmények terén nem volt statisztikai különbség a két csoportban, ezek eredményeit a 3. táblázat foglalja össze.

3. táblázat | Korai posztoperatív szövődmények

\begin{tabular}{|c|c|c|c|}
\hline & $\begin{array}{l}\text { Laparoszkópos } \\
(\mathrm{n}=33)\end{array}$ & $\begin{array}{l}\text { Nyitott } \\
(\mathrm{n}=23)\end{array}$ & \\
\hline $\begin{array}{l}\text { Reoperációt } \\
\text { igénylő }\end{array}$ & $\begin{array}{l}\text { - Ileus (2) } \\
\text { - Hasfali dysruptio } \\
\quad(1) \\
\text { - Stomakorrekció } \\
\quad(2)\end{array}$ & $\begin{array}{l}\text { - Ileus (3) } \\
\text { - Szeptikus állapot } \\
\quad(1)\end{array}$ & \\
\hline Összesen & $15,1 \%(5 / 33)$ & $17,4 \%(4 / 23)$ & $\mathrm{p}=0,822$ \\
\hline $\begin{array}{l}\text { Reoperációt } \\
\text { nem igénylő }\end{array}$ & $\begin{array}{l}\text { - Subileus (3) } \\
\text { - Alhasi tályog (1) } \\
\text { - Pouchitis (1) }\end{array}$ & $\begin{array}{l}\text { - Subileus (1) } \\
\text { - Per anum vérzés } \\
\quad(1) \\
\text { - Exsiccosis }(1) \\
\text { - Hydrothorax (1) } \\
\text { - Vizelési panaszok } \\
\quad(1)\end{array}$ & \\
\hline Összesen & $15,1 \%(5 / 33)$ & $21,7 \%(5 / 23)$ & $\mathrm{p}=0,527$ \\
\hline
\end{tabular}

A késői időszakot áttekintve a laparoszkópos betegcsoportnál szignifikánsan kevesebb szeptikus szövődményt, intestinalis obstrukciót és egyéb szövődményeket észleltünk, amelyeket a 4. táblázatban foglaltunk össze. A minimálisan invazív csoportban szeptikus állapot miatt 3 betegnél történt tályog miatt intervenciós, illetve mútéti beavatkozás. Ileus miatt 1 esetben végeztünk exploratiót, míg 7 subileus oldódott meg gyógyszeres kezelésre. 3 betegnél észleltünk posztoperatív sérvet az ileostoma hegében. 1 esetben akut hasi kórkép, az ileum vascularis károsodása miatt végeztünk mútétet. 1 anastomosisszúkület endoszkópos tágítása történt.

A nyitott módszerrel operált csoportban súlyos pouchitis miatt 1 betegnél a pouch kiirtására kényszerültünk, perianalis tályog kapcsán 9 Seton-drenálást és kismedencei tályog miatt 1 feltárást végeztünk. Bélelzáródás, hasi panaszok miatt 5 mütét és 9 obszerváció történt. Median laparotomia hegében lévő sérvek miatt 4 hasfali re- konstrukciót végeztünk. Rectumexstirpatio 2 betegnél történt a súlyos záróizom-károsodás és a konzervatív kezelésre nem szünő vérzés kapcsán. Tágításra 6 anastomosis került, 2 pouch-vaginalis fistulát észleltünk.

Utánkövetésünk során 2 beteget vesztettünk el szájüregi tumor és cardiorespiratoricus insufficientia következményeként, CU-val összefüggő halálok nem volt.

A vizsgálati időszak alatt belgyógyászati visszavétel 9 , illetve 12 esetben volt, amelynek hátterében nagyrészt vérszegénység miatti transzfúziós igény és hasi panaszok voltak. A kontroll endoszkópos vizsgálatok alapján 17 pouchitis igazolódott, amelyhez 10 esetben cuffitis is társult, ez a pouch-csal rendelkező betegek 40\%-át érintette.

Szövődmények terén vizsgáltuk a sebgyógyulási zavar megjelenését, amelyet a laparoszkópos csoportban 8 esetben ( 5 - sebvonalban, 1 - gáton, l - drén helyén, 1 - hasfali resutura helyén), a nyitott beteganyagnál 7 esetben (4 - sebvonalban, l - bezárt ileostoma helyén, 1 - drén helyén, 1 - nyákfistula helyén) észleltünk, közülük 2, illetve 1 betegnél methicillinrezisztens Staphylococcus aureus-infekció igazolódott.

\section{Életminőség}

Vizsgáltuk a mútéti beavatkozásokat követő életminőségbeli változást általános állapot, testsúly és napi székletszám tekintetében. A betegek mútét előtti és jelenlegi általános állapotának meghatározását 1-10-ig terjedő szubjektív skála alapján adták meg, ahol 1 a legjobb, míg 10 a legrosszabb életminőséget jelentette. Ebben a tekintetben mindkét csoportban szignifikáns javulást mértünk a műtétet követő időszakban. A mütétek utáni időszakban mindkét csoportban testtömeg-növekedést tapasztaltunk, amely a nyitott beteganyagnál szignifikánsnak bizonyult. A posztoperatív időszakban javult, azaz csökkent a napi átlagos székletszám mindkét csoportban. A két betegcsoport kozmetikai eredményét vizsgálva a betegek ötös skálán (egyáltalán nem elégedett - kicsit elégedett - közepesen elégedett - inkább elégedett - nagyon elégedett) értékeltek, amely alapján a nyitott mútéten átesett betegek az „inkább elégedett”, a laparoszkópos mútéten átesett betegek a „nagyon elégedett" választ adták. Az életminőségbeli változásokat az 5. táblázatban foglaltuk össze.

\section{Megbeszélés}

Vizsgálatunk az első hosszú távú magyarországi tanulmány a CU sebészi kezelését illetően, amely nagy hangsúlyt fektet a laparoszkópos beavatkozások eredményességének megítélésére is. A minimálisan invazív technika hazánkban is egyre nagyobb teret nyer, amely módszer az IBD kezelésében is széles körben, biztonsággal alkalmazható eljárás $[6,7,8]$. Tanulmányunkat három nagy részre (perioperatív időszak, mútét utáni komplikációk és életminőség) bontva, retrospektív módon vizsgáltuk a 
4. táblázat | Késői posztoperatív szövődmények

\begin{tabular}{|c|c|c|c|}
\hline & Laparoszkópos $(\mathrm{n}=33)$ & Nyitott $(\mathrm{n}=23)$ & \\
\hline Szeptikus állapot & $\begin{array}{l}\text { - Kismedencei tályog }(1) \rightarrow \text { intervenciós } \\
\text { drenálás } \\
\text { - Hasfali tályog }(1) \rightarrow \text { lokális kezelés } \\
\text { - Perianalis tályog }(1) \rightarrow \text { Seton-drenálás }\end{array}$ & $\begin{array}{l}\text { - Súlyos pouchitis }(1) \rightarrow \text { pouchexcisio } \\
\text { - Perianalis tályog }(9) \rightarrow \text { Seton-drenálás } \\
\text { - Kismedencei tályog }(1) \rightarrow \text { mútéti feltárás }\end{array}$ & \\
\hline Összesen & $9 \%(3 / 33)$ & $47,8 \%(11 / 23)$ & $\mathrm{p}=0,001$ \\
\hline \multicolumn{4}{|l|}{ Intestinalis obstrukció } \\
\hline - Műtéti beavatkozást igénylő & - Ileus $(1)$ & - Ileus $(5)$ & \\
\hline - Mütéti beavatkozást nem igénylő & - Subileus (7) & - Subileus (9) & \\
\hline Összesen & $24,2 \%(8 / 33)$ & $60,1 \%(14 / 23)$ & $\mathrm{p}=0,006$ \\
\hline Posztoperatív sérv & - Ileostoma hegében (3) & - Median laparotomia hegében (4) & \\
\hline Összesen & $9 \%(3 / 33)$ & $17,4 \%(4 / 23)$ & $\mathrm{p}=0,355$ \\
\hline Egyéb & $\begin{array}{l}\text { - Anastomosisstenosis }(1) \\
\text { - Akut has, szabad hasi levegó }(1) \rightarrow \\
\text { ileumresectio perforáció miatt }\end{array}$ & $\begin{array}{l}\text { - Anastomosisstenosis }(6) \\
\text { - Per anum vérzés }(3) \rightarrow \text { rectumexstirpatio } \\
\\
\quad(1) \\
\text { - Súlyos spinchterkárosodás }(1) \rightarrow \\
\text { rectumexstirpatio } \\
\text { - Pouch-vaginalis fistula }(2) \\
\text { - Exsiccosis }(2)\end{array}$ & \\
\hline Összesen & $6 \%(2 / 33)$ & $60,1 \%(14 / 23)$ & $\mathrm{p}=0,01$ \\
\hline
\end{tabular}

5. táblázat | Pre- és posztoperatív életminőségbeli változtatások

\begin{tabular}{|c|c|c|c|c|}
\hline & & Mútét előtt & Jelenleg & \\
\hline \multirow{2}{*}{$\begin{array}{l}\text { Életminőség } \\
\text { (skála alapján) }\end{array}$} & Laparoszkópos $(\mathrm{n}=33)$ & $8,55 \pm 1,5$ & $2,65 \pm 1,92$ & $\mathrm{p}=0,000$ \\
\hline & Nyitott $(\mathrm{n}=23)$ & $8,69 \pm 1,74$ & $2,63 \pm 1,96$ & $\mathrm{p}=0,000$ \\
\hline \multirow[t]{2}{*}{ Napi székletszám } & Laparoszkópos $(\mathrm{n}=33)$ & $10,51 \pm 5,77$ & $8,16 \pm 4,21$ & $\mathrm{p}=0,352$ \\
\hline & Nyitott $(\mathrm{n}=23)$ & $9,73 \pm 5,27$ & $8,71 \pm 3,14$ & $\mathrm{p}=0,632$ \\
\hline \multirow[t]{2}{*}{ Testsúly (kg) } & Laparoszkópos $(\mathrm{n}=33)$ & $65,33 \pm 14,72$ & $72,08 \pm 18,37$ & $\mathrm{p}=0,126$ \\
\hline & Nyitott $(\mathrm{n}=23)$ & $62,45 \pm 16,18$ & $73,21 \pm 14,7$ & $\mathrm{p}=0,033$ \\
\hline
\end{tabular}

CU miatt nyitott, illetve minimálisan invazív módszerrel operált betegcsoportokat. A betegség terápiája elsősorban gyógyszeres és biológiai kezelésen alapszik, sebészeti megoldása, ennek sikertelensége, illetve életet veszélyeztető állapotromlás, akut hasi kórkép esetén szükséges. A kórkép incidenciája emelkedik, becslések szerint a CUban szenvedő populáció 25-40\%-ánál kényszerülünk mútéti beavatkozásra $[2,9,10,11,12,13]$.

A proctocolectomiát követő első pouchműtétről 1978-ban Parks és munkacsoportja számolt be, amely módszer a CU sebészi kezelését illetően napjainkra gold standard alternatívává vált, laparoszkópos változatáról elsőként a kilencvenes évek elején tesznek említést [3, 4, 14]. Egy nagy esetszámmal dolgozó japán, valamint egy francia tanulmány is az IPAA-t mint legjobb megoldást emeli ki [13, 15].

Utánkövetésünk átlagosan 47,84 (3-111) hónapig tartott. Az 56 eset közül laparoszkópos technikával 33 (58,9\%), nyitottan $23(41,1 \%)$ mütét történt, 20 (35,7\%) sürgősséggel, míg $36(64,3 \%)$ tervezett úton. A laparoszkópos beavatkozások közül összesen 3 esetben
$(3 / 36,8,3 \%$,$) , tervezett mútét kapcsán masszív adhézi-$ ók (1 eset), valamint sürgős műtét során észlelt bélsérülés, illetve perforáció veszélye miatt ( 2 eset) kényszerültünk konverzióra, a késóbbi elemzésekből ezeket az eseteket kizártuk. Egy amerikai tanulmányban a konverzió okaként a beavatkozások sürgős jellegét, a korábbi hasi mútétek mellett a proctectomiát is megemlítik, valamint az IBD tekintetében a Crohn-betegséget [16].

A betegség megjelenésétôl a mütéti beavatkozásig át-

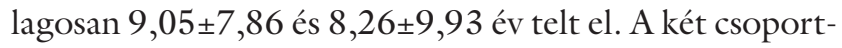
ban a BMI-t és az ASA-klasszifikációt illetően különbséget nem találtunk. Műtét előtti laborértékekben a gyulladásos markerek a nyitott beteganyagnál szignifikánsan magasabbnak bizonyultak, amit a csoportban lévő akut mútétek magasabb arányának tulajdonítunk. Extraintestinalis manifesztációra utaló eltérést 42 betegnél észleltünk.

Számos tanulmány foglalkozott a CU és a dohányzás kapcsolatával, amelyek szerint az protektív hatással bír a betegség kialakulásával, fellángolásával szemben [9, 17]. Hasonló megfigyelés igazolódott appendectomia - mint 
védőtényező - megfigyelése kapcsán is [9, 18]. Beteganyagunkban nem szerepelt aktív dohányos, kórtörténetükben 8 esetben igazolódott korábbi dohányzás és 2 betegnél szerepelt appendectomia.

A két csoport ápolási idejében, intenzív osztályos és transzfúziós igényében, valamint az első széklet megjelenéséig eltelt időben különbséget nem találtunk. A nyitott módon elvégzett mútétek rövidebb ideig tartottak, amely a nyákfistula-, végileostoma-képzéssel járó colectomiák esetén szignifikánsnak bizonyult.

Az eddig publikált tanulmányok jelentős része a laparoszkópos technika különböző előnyeiről számolt be Egy ausztrál tanulmány szerint a laparoszkópia rövidebb ápolási idővel bír, gyorsabb a passzázs helyreállása, kozmetikailag előnyösebb, azonban proctocolectomia kapcsán azonos a morbiditása a két mütéti technikának [19]. Gu és mtsai a laparoszkópos colectomiát követő laparoszkópos kiegészítő proctectomiákat, IPAA kialakítását vizsgálva alacsony vérvesztésről, a passzázs gyors helyreállásáról és rövid ápolási időről tesznek említést [20]. A nem toxikus colitis miatt végzett colectomiák kapcsán készült holland tanulmány a sebfertőzés és a hasi tályog esetén látja előnyösebbnek a minimálisan invazív technikát [21]. Koh és mtsai a CU miatti urgens laparoszkópos mútétek vizsgálata alapján azt biztonságosnak találták, ileus és sebfertőzés terén jobb eredményeket írtak le a nyitott mútétekhez képest [22]. Két amerikai tanulmány hasonlóan kedvező eredményeket közölt ápolási idő, vérigény, kozmetikai eredmény, sebfertőzés terén sürgőséggel végzett laparoszkópos szubtotális colectomiák kapcsán $[23,24]$. Egy nagy nemzetközi adatbázis adatai alapján a minimálisan invazív betegcsoport kedvezőbb eredményekkel bír morbiditás és mortalitás szempontjából [6]. Míg egy 2013-ban megjelent randomizált tanulmány a laparoszkópos módszernek csupán a kozmetikai előnyét igazolta [25]. Egy rövid távú utánkövetés nem talált különbséget IPAA-mútéteket követően ápolási idő, passzázsmegindulás és komplikációk terén a két csoport összehasonlítása kapcsán [26].

A posztoperatív szövődményeket megvizsgálva a korai, 30 napon belüli időszakban a laparoszkópos és a nyitott csoport között nem találtunk különbséget a reoperációt igénylő $(15,15 \%$ vs. $17,39 \%)$ és konzervatív kezeléssel orvosolható komplikációk (15,15\% vs. 21,7\%) között. A mütét előtti időszakban 23 beteg $(41,07 \%)$ részesült infliximabkezelésben, 6 esetben alakult ki korai szövődmény. Irodalmi adatok alapján megoszló vélemények vannak a biológiai terápia és a mútét utáni komplikációk összefüggését illetően, valamint a legfrissebb, ezzel a témával foglalkozó összefoglaló közlemény alapján még túl korai a biológiai terápiák mütétet befolyásoló hatásának megítélése [27, 28, 29].

Késői szövődmények terén azonban a laparoszkópos műtéti technika egyértelműen kedvezőbb eredményekkel bír szeptikus szövődmények, intestinalis obstrukció és egyéb komplikációk terén, úgymint anastomosisszúkület, pouch-vaginalis fistula, per anum vérzés. Sebgyó- gyulási zavar (24\% vs. $30 \%)$ tekintetében nem találtunk különbséget.

A nyitott csoportban az intestinalis obstrukciók magasabb aránya $(24,2 \%$ vs. $60 \%)$ a beavatkozás jellegéből adódó nagyobb mútéti traumával és vélhetően az összenövések magasabb rizikójával magyarázható, azonban az erre vonatkozó irodalmi adatok eltérőek. Feltevésünket támasztja alá az a két tanulmány, ahol szignifikánsan kevesebb hasüri és kismedencei adhéziót igazoltak laparoszkópos IPAA-t követően, ezáltal csökkentve az ileus és nói infertilitás kialakulásának lehetőségét [30, 31]. Dolejs publikációja szerint a laparoszkópia nem változtatja meg az intestinalis obstrukció rizikóját [32]. Szintén kevesebb, laparoszkópos mútét utáni összenövésről és sérvról számol be egy holland munkacsoport [33]. A laparoszkópos csoportban csupán a protektív ileostomák helyén $(9 \%)$, míg a nyitott esetekben a nagy behatolási kapuval bíró median laparotomiákban (17,3\%) észleltünk mütét utáni sérveket. A Wu és munkacsoportja által készített összefoglaló tanulmány nem talált különbséget hasüri tályog, varratelégtelenség és ileus kapcsán a két csoport között [34]. Egy 2014-es összefoglaló közlemény a laparoszkópos IPAA előnyeként az alacsony morbiditást, a rövid ápolási időt és a magasabb fertilitást emeli ki a hosszab mútéti idővel szemben, míg akut esetekben az alacsonyabb szeptikus szövődményt és a sebgyógyulási zavart említi [35]. Gu és mtsai laparoszkópos totális colectomiák kapcsán vezető komplikációként distaliscsonk-elégtelenségből fakadó szeptikus szövődményeket, ileust és sebgyógyulási zavart regisztráltak [36].

Utánkövetésünk során pouchitist a betegek $40 \%$-ánál regisztráltunk, egy esetben a súlyos gyulladás miatt a pouch kiirtására kényszerültünk, 2 pouch-vaginalis fistulát észleltünk. Szövődményeinket áttekintve a pouch gyulladásos folyamata az egyik leggyakrabban észlelt probléma volt. Egy angol összefoglaló közleményben az IPAA-t követő komplikációkat a pouch gyulladása vezeti, hasonló eredményre jutott egy nagy esetszámmal dolgozó finn tanulmány is $[37,38]$.

Sebészi beavatkozásokat követően szignifikáns életminőségbeli javulást tapasztaltunk, amely eredmény számos irodalmi adattal korrelál [39, 40, 41, 42]. Mindként csoportban csökkent a napi székletszámok átlaga, valamint testsúlygyarapodást tapasztaltunk. A minimálisan invazív beavatkozásokat követően kedvezőbb kozmetikai eredményt értünk el.

Egy olasz tanulmány az IPAA-t követő komplikációk, pouchitis, pouchexcisio veszélye, tumorrizikó, illetve életminőség kapcsán hívja fel a figyelmet a műtétre kerülő betegek pontos kivizsgálásának, szelekciójának és utánkövetésének fontosságára [43].

Vizsgálatunk alapján elmondhatjuk, hogy a CU kezelésében a laparoszkópos módszer tervezett és sürgősségi esetekben is biztonságosan alkalmazható eljárás, amely kedvező hosszú távú eredményekkel bír. A hagyományos, nyitott módszerhez képest alacsony szövődményráta mellett jó életminőséget és előnyösebb kozmetikai 
eredményt biztosít. A CU-ban szenvedő populáció egy „nehéz” beteganyag, amelynek kezelése, gondozása dedikált centrumokban javasolt gasztroenterológus és a sebész szoros együttmúködésével.

Anyagi támogatás: A közlemény megírása, illetve a kapcsolódó kutatómunka anyagi támogatásban nem részesült.

Szerzői munkamegosztás: A beteganyag feldolgozását jr. T. J. végezte. A többi szerző a betegek sebészeti, illetve belgyógyászati kezelését, valamint gondozását, utánkövetését végezte. A kézirat végleges változatát valamennyi szerző elolvasta és jóváhagyta.

Érdekeltségek: A szerzőknek nincsenek érdekeltségeik.

\section{Irodalom}

[1] Jacobs, M., Verdeja, J. C., Goldstein, H. S.: Minimally invasive colon resection (laparoscopic colectomy). Surg. Laparosc. Endosc., 1991, 1(3), 144-150.

[2] Mibeller, P., Nagy, F., Palatka, K., et al.: Some data on inflammatory bowel diseases in Hungary: analytical data on ulcerative colitis. [Magyarországi adatok a gyulladásos bélbetegségről: analitikai adatok a colitis ulcerosáról.] Orv. Hetil., 2012, 153(18), 702-712. [Hungarian]

[3] Bennis, M., Tiret, E.: Surgical management of ulcerative colitis. Langenbeck's Arch. Surg., 2012, 397(1), 11-17.

[4] Peters, W. R.: Laparoscopic total proctocolectomy with creation of ileostomy for ulcerative colitis: report of two cases. J. Laparoendosc. Surg., 1992, 2(3), 175-178.

[5] Zoccali, M., Fichera, A.: Minimally invasive approaches for the treatment of inflammatory bowel disease. World J. Gastroenterol., 2012, 18(46), 6756-6763.

[6] Causey, M. W., Stoddard, D., Johnson, E. K., et al.: Laparoscopy impacts outcomes favorably following colectomy for ulcerative colitis: a critical analysis of the ACS-NSQIP database. Surg. Endosc., 2013, 27(2), 603-609.

[7] Hata, K., Kazama, S., Nozawa, H., et al.: Laparoscopic surgery for ulcerative colitis: a review of the literature. Surg. Today, 2015, 45(8), 933-938.

[8] Sica, G. S., Biancone, L.: Surgery for inflammatory bowel disease in the era of laparoscopy. World J. Gastroenterol., 2013, 19(16), 2445-2448.

[9] Kovács, Á., Lakatos, L.: Inflammatory bowel diseases. [Gyulladásos bélbetegségek.] Medicina Könyvkiadó, Budapest, 2011. [Hungarian]

[10] Bach, S. P. Mortensen, N. J.: Ileal pouch surgery for ulcerative colitis. World J. Gastroenterol., 2007, 13(24), 3288-3300.

[11] Ferrante, M., Declerck, S., De Hertogh, G., et al.: Outcome after proctocolectomy with ileal pouch-anal anastomosis for ulcerative colitis. Inflamm. Bowel Dis., 2008, 14(1), 20-28.

[12] Roses, R. E., Rombeau, J. L.: Recent trends in the surgical management of inflammatory bowel disease. World J. Gastroenterol., 2008, 14(3), 408-412.

[13] Ikeuchi, H., Uchino, M., Matsuoka, H., et al.: Surgery for ulcerative colitis in 1,000 patients. Int. J. Colorectal Dis., 2010, 25(8), 959-965.

[14] Parks, A. G., Nicholls, R. J.: Proctocolectomy without ileostomy for ulcerative colitis. Br. Med. J., 1978, 2(6130), 85-88.

[15] Lefevre, J. H., Bretagnol, F., Onaïsi, M., et al.: Total laparoscopic ileal pouch-anal anastomosis: prospective series of 82 patients. Surg. Endosc., 2009, 23(1), 166-173.
[16] Masoomi, H., Moghadamyeghaneh, Z., Mills, S., et al.: Risk factors for conversion of laparoscopic colorectal surgery to open surgery: does conversion worsen outcome? World J. Surg., 2015, 39(5), 1240-1247.

[17] Tobin, M. V., Logan, R. F., Langman, M. J., et al.: Cigarette smoking and inflammatory bowel disease. Gastroenterology, 1987, 93(2), 316-321.

[18] Gilat, T., Dotan, I.: Ulcerative colitis and appendectomy. What is the nature of the (negative) association? Ital. J. Gastroenterol. Hepatol., 1997, 29(3), 212-213.

[19] Tan, J. J., Tjandra, J. J.: Laparoscopic surgery for ulcerative colitis - a meta-analysis. Colorectal Dis., 2006, 8(8), 626-636.

[20] Gu, J., Stocchi, L., Geisler, D. P., et al.: Staged restorative proctocolectomy: laparoscopic or open completion proctectomy after laparoscopic subtotal colectomy? Surg. Endosc., 2011, 25(10), 3294-3299.

[21] Bartels, S. A., Gardenbroek, T. J., Ubbink, D. T., et al.: Systematic review and meta-analysis of laparoscopic versus open colectomy with end ileostomy for non-toxic colitis. Br. J. Surg., 2013, 100(6), 726-733.

[22] Koh, F. H., Tan, K. K., Tsang, C. B., et al.: Laparoscopic versus an open colectomy in an emergency setting: a case-controlled study. Ann. Coloproctol., 2013, 29(1), 12-16.

[23] Bell, R. L., Seymour, N. E.: Laparoscopic treatment of fulminant ulcerative colitis. Surg. Endosc., 2002, 16(12), 1778-1782.

[24] Telem, D. A., Vine, A. J., Swain, G., et al.: Laparoscopic subtotal colectomy for medically refractory ulcerative colitis: the time has come. Surg. Endosc., 2010, 24(7), 1616-1620.

[25] Schiessling, S., Leowardi, C., Kienle, P., et al.: Laparoscopic versus conventional ileoanal pouch procedure in patients undergoing elective restorative proctocolectomy (LapConPouch Trial) - a randomized controlled trial. Langenbeck's Arch. Surg., 2013, 398(6), 807-816.

[26] Fajardo, A. D., Dharmarajan, S., George, V., et al.: Laparoscopic versus open 2-stage ileal pouch: laparoscopic approach allows for faster restoration of intestinal continuity. J. Am. Coll. Surg., 2010, 211(3), 377-383.

[27] Coquet-Reinier, B., Berdah, S. V., Grimaud, J. C., et al.: Preoperative infliximab treatment and postoperative complications after laparoscopic restorative proctocolectomy with ileal pouchanal anastomosis: a case-matched study. Surg. Endosc., 2010, 24(8), 1866-1871.

[28] Mor, I. J., Vogel, J. D., da Luz Moreira, A., et al.: Infliximab in ulcerative colitis is associated with an increased risk of postoperative complications after restorative proctocolectomy. Dis. Colon Rectum, 2008, 51(8), 1202-1207; discussion 1207-1210.

[29] Øresland, T., Faerden, A. E.: Surgery in the age of biological treatment. Scand. J. Gastroenterol., 2015, 50(1), 121-127.

[30] Hull, T. L., Joyce, M. R., Geisler, D. P., et al.: Adhesions after laparoscopic and open ileal pouch-anal anastomosis surgery for ulcerative colitis. Br. J. Surg., 2012, 99(2), 270-275.

[31] Indar, A. A., Efron, J. E., Young-Fadok, T. M.: Laparoscopic ileal pouch-anal anastomosis reduces abdominal and pelvic adhesions. Surg. Endosc., 2009, 23(1), 174-177.

[32] Dolejs, S., Kennedy, G., Heise, C. P.: Small bowel obstruction following restorative proctocolectomy: affected by a laparoscopic approach? J. Surg. Res., 2011, 170(2), 202-208.

[33] Bartels, S. A., Vlug, M. S., Henneman, D., et al.: Less adhesiolysis and hernia repair during completion proctocolectomy after laparoscopic emergency colectomy for ulcerative colitis. Surg. Endosc., 2012, 26(2), 368-373.

[34] Wu, X. J., He, X. S., Zhou, X. Y., et al.: The role of laparoscopic surgery for ulcerative colitis: systematic review with meta-analysis. Int. J. Colorectal Dis., 2010, 25(8), 949-957.

[35] Buskens, C. J., Sabami, S., Tanis, P. J., et al.: The potential benefits and disadvantages of laparoscopic surgery for ulcerative colitis: A review of current evidence. Best Pract. Res. Clin. Gastroenterol., 2014, 28(1), 19-27. 
[36] Gu, J., Stocchi, L., Remzi, F., et al.: Factors associated with postoperative morbidity, reoperation and readmission rates after laparoscopic total abdominal colectomy for ulcerative colitis. Colorectal Dis., 2013, 15(9), 1123-1129.

[37] Sagar, P. M., Pemberton, J. H.: Intraoperative, postoperative and reoperative problems with ileoanal pouches. Br. J. Surg., 2012, 99(4), 454-468.

[38] Helavirta, I., Hubtala, H., Hyoty, M., et al.: Restorative proctocolectomy for ulcerative colitis in 1985-2009. Scand. J. Surg., 2015 Jun 10. pii: 1457496915590540 . [Epub ahead of print]

[39] Andersson, T., Lunde, O. C., Johnson, E., et al.: Long-term functional outcome and quality of life after restorative proctocolectomy with ileo-anal anastomosis for colitis. Colorectal Dis. $2011,13(4), 431-437$.

[40] Heikens, J. T., de Vries, J., van Laarhoven, C. J.: Quality of life, health-related quality of life and health status in patients having restorative proctocolectomy with ileal pouch-anal anastomosis for ulcerative colitis: a systematic review. Colorectal Dis., 2012, 14(5), 536-544.

[41] Leowardi, C., Hinz, U., Tariverdian, M., et al.: Long-term outcome 10 years or more after restorative proctocolectomy and ileal pouch-anal anastomosis in patients with ulcerative colitis. Langenbeck's Arch. Surg., 2010, 395(1), 49-56.

[42] Raviram, S., Rajan, R., Sindhu, R. S., et al.: Quality of life, social impact and functional outcome following ileal pouch-anal anastomosis for ulcerative colitis and familial adenomatous polyposis. Indian J. Gastroenterol., 2015, 34(3), 252-255.

[43] Delaini, G. G., Scaglia, M., Colucci, G., et al.: The ileoanal pouch procedure in the long-term perspective: a critical review. Techn. Coloproctol., 2005, 9(3), 187-192.

(Lázár György dr., Szeged, Szőkefalvi-Nagy u. 6., 6720 e-mail: gylazar@gmail.com)

\section{A rendezvények és kongresszusok híranyagának leadása}

a lap megjelenése előtt legalább 40 nappal lehetséges, a 6 hetes nyomdai átfutás miatt. Kérjük megrendelőink szíves megértését.

A híranyagokat a következő címre kérjük: Orvosi Hetilap titkársága: Budai.Edit@akkrt.hu Akadémiai Kiadó Zrt. 



\title{
Effect of Laparoscopic Surgery on Quality of Life in Ulcerative Colitis
}

\author{
János Tajti Jr., MD, Melinda Látos, PhD, ${ }^{1}$ Klaudia Farkas, MD, PhD, \\ Szabolcs Ábrahám, MD, PhD, Zsolt Simonka, MD, PhD, Attila Paszt, MD, PhD, \\ Tamás Molnár, MD, PhD, and György Lázár, MD, PhD, DSc ${ }^{1}$
}

\begin{abstract}
Aim: To evaluate quality of life after surgery for ulcerative colitis (UC) the gastroenterological and psychological conditions were examined.

Materials and Methods: Between January 1, 2005 and March 1, 2016, surgery was performed for UC in a total of 75 patients. Our examinations were performed in 58 cases. Quality of life was examined with questionnaires. Functional Scoring System, Gastrointestinal Quality of Life Index (GIQLI), and Short Inflammatory Bowel Disease Questionnaire (SIBDQ) were used for testing gastroenterological conditions; Spielberger's State-Trait Anxiety Questionnaire, Beck Depression Inventory, and Brief Illness Perception Questionnaire (BIPQ) were performed to consider psychological status.

Results: Trait anxiety and the incidence of abdominal pain were significantly lower in patients having undergone laparoscopic surgery. No difference was found between the minimally invasive and conventional methods in the early complications. There were significantly more late complications developing after 30 days in patients who had undergone open surgery. Differences were found in personal control between patients with a stoma and patients without a stoma. Patients with a stoma felt they had less control over their disease. A significant correlation was found between the results of the psychological and gastrointestinal questionnaires.

Conclusions: Minimally invasive technique provides a better long-term outcome for patients with UC, fewer complications, and a more balanced emotional condition. Favorable gastroenterological condition leads to better psychological status, which is negatively influenced by stoma or complications.
\end{abstract}

Keywords: colitis, ulcerative, laparoscopy, quality of life, psychology, clinical, stomas, surgical

\section{Introduction}

$\mathbf{U}$ LCERATIVE COLITIS (UC) Is a chronic inflammatory disease affecting the whole large intestine. The incidence of UC has risen recently. The incidence of Inflammatory Bowel Diseases (IBD) is 11.3/100,000 in Eastern Europe, 14.0/100,000 in Western Europe, and it is estimated to be 24/ 100,000 in Hungary. ${ }^{1}$ Treatment of the disease is primarily drug therapy; however, surgical intervention is required in the case of patients not responding to conservative therapy or in the case of complications.

The gold standard surgical treatment is proctocolectomy and ileal pouch-anal anastomosis (IPAA), using standard, open, and laparoscopic methods, ${ }^{2}$ The aim of surgical intervention is to improve long-term quality of life by removing the target organ, the whole large intestine, ${ }^{3,4}$ The benefits of the minimally invasive method in the surgical treatment of $\mathrm{UC}$ are the following: length of hospital stay is shorter, postoperative pain is reduced, passage resolves rapidly, and cosmetic results are beneficial, ${ }^{5}$ The importance of surgical treatment is supported by two studies that show that patients treated with conservative methods experienced a worse longterm quality of life compared to those receiving surgical treatment, ${ }^{6,7}$ As a result, it can be concluded that surgery provides successful treatment for UC in the long term and it is therefore important to inform the patients about it. Limited

\footnotetext{
${ }^{1}$ Department of Surgery and ${ }^{2}$ First Department of Internal Medicine, University of Szeged, Szeged, Hungary.
} 
data are available on quality of life in patients with UC undergoing surgery. Our working group was the first to publish mid- and long-term results on laparoscopic treatment of UC in Hungary, which proved the success of the method. ${ }^{8,9}$

The purpose of our study is to evaluate quality of life for patients who have had surgery due to UC. Quality of life was studied in patients who had undergone laparoscopic and open surgeries, in patients with or without stoma, regarding early and late complications, and in the case of elective and emergency indications. We were looking for a connection between gastroenterological and psychological conditions, daily activities.

\section{Materials and Methods}

Between January 1, 2005 and March 1, 2016, surgery was performed due to UC in a total of 75 patients, the open method was used in 25 cases and the minimally invasive technique in 50. All procedures performed in this study involving human participants were conducted with the approval of the Ethics Committee at the University of Szeged, Hungary (194/2015-SZTE) and were in accordance with the Helsinki Declaration of 1975 (1983) and its later amendments or comparable ethical standards. Our examinations were carried out in 58 of the 75 patients. Questionnaires could not be completed for various reasons for 17 patients (death in 3 cases, language problems occurred in the case of 2 foreign patients, and 12 patients refused to participate in the study or could not be contacted).

The average duration of the follow-up was 46 (1-124) months. Fifty-eight patients (29 female and 29 male) participated in our study; 41 patients had undergone laparoscopic surgery, and 17 patients had had open surgeries. Thirty-nine cases were elective interventions, while 19 were emergency surgery due to unsuccessful conservative treatment or fulminant, septic, or toxic condition. No significant difference was found in the case of the body mass index $(24.85 \pm 5.12$ versus $26.82 \pm 5.57$ ) or the American Society of Anesthesiologists (ASA) score $(2.25 \pm 0.54$ versus $2.13 \pm 0.74)$. There was an average 8.2 years from diagnosing the disease to surgery. In the laparoscopic group, 25 proctocolectomies with IPAA and ileostomy were performed, 13 patients had a total colectomy with end ileostomy and mucous fistula, and 3 rectum extirpations were carried out. In the open group, a pouch was created in 4 cases, 9 patients had a total colectomy with mucous fistula, and 4 other colon resections were performed. Seventeen patients had a stoma during the study. To homogenize the groups, 6 patients, who were operated dissimilarly from the standard surgical technique ( $n=3$ rectum exstirpation, $n=3$ other colon resection) were excluded during the comparison of laparoscopic and open surgery groups, and during the analysis of complications.

\section{Questionnaires}

Functional scoring system. The functional scoring system is a questionnaire consisting of 12 questions on patients' bowel movements (number of bowel movements during the day and at night, urgency, and perianal soreness), incontinence (during the day and at night and use of protective pads), diet, drug therapy, and potential social disadvantages. ${ }^{10}$
Gastrointestinal Quality of Life Index. The Gastrointestinal Quality of Life Index (GIQLI) studies gastroenterological condition (abdominal pain, epigastric fullness, bloating, flatulence, eructation, increased bowel movements, urgency, diarrhea, constipation, nausea, blood in the stool, heartburn, and bowel incontinence), alimentation (appetite, eating speed, and swallowing a bite), physical condition, daily activities, social activities, and psychological condition for 2 weeks before completing the questionnaire. ${ }^{11}$

Short IBD Questionnaire. The Short IBD Questionnaire (SIBDQ) studies gastrointestinal symptoms and their effect on social and physical well-being for 2 weeks before completing the questionnaire based on 10 questions. ${ }^{12}$

Spielberger's State-Trait Anxiety Questionnaire and the Beck Depression Inventory. Spielberger's State-Trait Anxiety Questionnaire and the Beck Depression Inventory were used to measure the level of anxiety and mood. ${ }^{13,14}$

Brief Illness Perception Questionnaire. Illness perceptions and attitude toward healing were studied using the Brief Illness Perception Questionnaire (BIPQ), consisting of eight subscales (consequences, timeline, personal control, treatment control, identity, concern, coherence, and emotional representation). ${ }^{15}$

\section{Biostatistics}

Patients were examined retrospectively, and statistical analysis was performed with the SPSS program (Version 20.0 2014; IBM SPSS Statistics, Chicago, IL). Pearson and Spearman correlations were used to determine relationships between variables. The independent samples $t$-test, MannWhitney test, ANOVA, and Chi-square test were used to compare the groups. Values were considered to be statistically significant if $P$ was lower than .05 .

\section{Results}

\section{Representation of illnesses}

About $92.3 \%$ of the patients enrolled in the study considered a psychological factor (psychological causes, family, or work stress) to be in the background of their disease. Around $42.3 \%$ of the patients pointed to genetic factors, $46.2 \%$ of them mentioned environmental hazards (such as inappropriate diet), and 1 patient noted the Chernobyl nuclear disaster as the cause of the disease.

Patients viewing genetic factors as being in the background of the disease reached significantly higher scores on the BIPQ (44.14 \pm 11.64 versus $35.73 \pm 13.35 ; P=.022)$, so they are more threatened by their disease and know less about the nature of it (coherence subscale: $2.14 \pm 1.58$ versus $1.10 \pm 1.32 ; P=.013)$.

\section{Psychological consequences of having a stoma}

There were differences in personal control between patients with a stoma $(n=17)$ and patients without a stoma $(n=41)(6.12 \pm 3.33$ versus $4.12 \pm 2.88 ; P=.045)$. Patients with a stoma felt they had less control over their disease. No difference was found between the two groups during gastroenterological follow-up examinations. 


\section{Results for emotional state and mood}

There was a significant connection between depression and the functional scoring system $(P=.002 ; r=0.419)$, GIQLI $(P<.001 ; r=-0.867)$, SIBDQ $(P<.001 ; r=-0.795)$, and BIPQ $(P<.001 ; r=0.751)$, in addition to the consequences, personal and treatment control, identity, concern, and emotional representation subscales $(P<.05$ in all cases). State anxiety significantly correlated with the total score for the GIQLI $(P<.001 ; r=-0.624)$, SIBDQ $(P<.001 ; r=-0.579)$, and BIPQ $(P<.001 ; r=0.615)$, along with the consequences, personal and treatment control, identity, concern, and emotional representation subscales $(P<.05$ in all cases). There was a significant connection between trait anxiety and the functional scoring system $(P=.012 ; r=0.344)$, GIQLI $(P<$ $.001 ; r=-0.682)$, SIBDQ $(P<.001 ; r=-0.684)$ and BIPQ $(P<.001 ; r=0.608)$, in addition to the consequences, personal and treatment control, identity, concern, and emotional representation subscales $(P<.001)$ (Table 1$)$.

\section{Comparing laparoscopy and open surgery}

Trait anxiety was significantly lower in patients having undergone laparoscopic surgery $(n=38)$ compared with patients who had had open surgery $(n=14)(P=.018)(\mathrm{av}-$ erage value of trait anxiety in patients with open surgery was 48.71, standard deviation $[\mathrm{SD}]=10.91$; this value was $40.22, \mathrm{SD}=9.82$ in the laparoscopic group). Both patient groups had $>5$ stools in the daytime and $>1$ at night per week, with no significant difference observed between the groups. No difference was noted between the two surgical methods based on the total score on the gastroenterological questionnaires, although the following statistical differences were found when evaluating each questionnaire item individually. Incontinence was registered during the day (25\% versus $27 \%)$ and at night $(39.28 \%$ versus $54 \%)$ in both patient groups (Table 2). The incidence of abdominal

Table 1. Pearson's or Spearman's Correlation Between Clinical and Psychological Variables and Gastrointestinal Quality of Life InDEX

\begin{tabular}{ll}
\hline Variables & GIQLI \\
\hline Psychological variables & \\
Beck depression inventory & $-0.87^{*}$ \\
Spielberger's State Anxiety Scale & $-0.62^{*}$ \\
Spielberger's Trait Anxiety Scale & $-0.69^{*}$ \\
Brief Illness Perception Questionnaire & $-0.84^{*}$ \\
Consequences & $-0.89^{*}$ \\
Timeline & $-0.07^{(\mathrm{NS})}$ \\
Personal control & $-0.37^{*}$ \\
Treatment control & $-0.39^{*}$ \\
Identity & $-0.73^{*}$ \\
Concern & $-0.71^{*}$ \\
Coherence & $\left.-0.01^{*} \mathrm{NS}\right)$ \\
Emotional representation & $-0.78^{*}$ \\
Clinical variables & \\
Functional scoring system & $-0.55^{*}$ \\
SIBDQ & $0.89^{*}$ \\
\hline
\end{tabular}

$* P<.01$.

GIQLI, Gastrointestinal Quality of Life Index; NS, non significant; SIBDQ, Short Inflammatory Bowel Disease Questionnaire.
Table 2. Total Values from the Functional SCORING SYSTEM

\begin{tabular}{lcr}
\hline & $\begin{array}{c}\text { Laparoscopic } \\
(\mathrm{n}=28) \mathrm{n}(\%)\end{array}$ & $\begin{array}{c}\text { Open } \\
(\mathrm{n}=11) \\
\mathrm{n}(\%)\end{array}$ \\
\hline $\begin{array}{l}\text { Urgency (inability to defer } \\
\quad \text { evacuation } \geq 30 \text { minutes) }\end{array}$ & $14(50)$ & $6(54.5)$ \\
$\begin{array}{l}\text { Evacuation difficulties } \\
\text { Soiling or seepage in daytime }\end{array}$ & $5(17.85)$ & $3(27.3)$ \\
$\begin{array}{l}\text { Soiling or seepage at night } \\
\text { Perianal soreness }\end{array}$ & $11(39)$ & $3(27.3)$ \\
Protective pad in daytime & $15(53.57)$ & $6(54.5)$ \\
Protective pad at night & $7(25)$ & $3(27.3)$ \\
$\begin{array}{l}\text { Dietary restrictions } \\
\text { Medication }\end{array} \quad 12(42.85)$ & $3(27.3)$ \\
$\quad$ continuous or occasional) & $21(75)$ & $5(45.5)$ \\
Social handicap & $14(50)$ & $10(90.9)$ \\
\hline
\end{tabular}

Based on Oresland et al. ${ }^{10}$

pain was significantly less common $(1.895 \pm 1.034$ versus $2.769 \pm 0.927 ; P=.024)$ in the laparoscopic group based on the GIQLI.

\section{Complications}

No difference was found between the minimally invasive and conventional methods in cases requiring early reoperation (ileus, stoma correction, bleeding, and sepsis) and in cases not requiring reoperation (subileus, bleeding, septic condition, pancreatitis, and dehydration). There were significantly more late complications developing after 30 days (septic condition, intestinal obstruction, postoperative hernia, and "other" complications, such as bleeding, anastomosis stenosis, pouch-vaginal fistula, perforation, and disruption of the abdominal wall) in patients who had undergone open surgery $(P=.001)$, of whom the incidence of intestinal obstruction and "other" complications were significantly higher $(P \leq .001)$ (Fig. 1). Pouchitis was detected in 17 cases

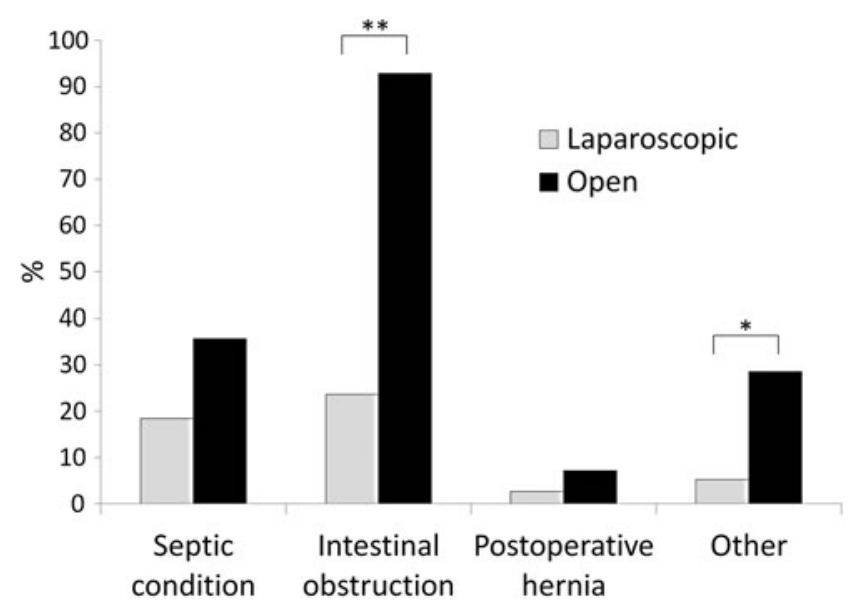

FIG. 1. Late postoperative complications. Among late complications the incidence of intestinal obstruction $(* * P \leq .001)$ and "other" complications $(* P \leq .05)$ were significantly higher in patients who had had open surgery than in patients who had undergone laparoscopic surgery. 
(35.41\% of patients with a pouch). Cuffitis occurred in 13 $(27.08 \%)$ cases. The personal control $(3.43 \pm 2.35$ versus $5.57 \pm 3.31 ; P=.024)$ was higher in patients with no late complication.

\section{Discussion}

Our study confirmed the long-term positive effect of laparoscopic surgery on quality of life in the surgical treatment of UC. A favorable gastroenterological condition leads to a better psychological state, which can be negatively influenced by the presence of stoma or complications. By positively influencing these factors, using a minimally invasive technique results in better quality of life compared with open surgery.

In the case of a benign, non-neoplastic disease, the success of the surgical intervention is determined by the quality of life. In the case of UC, abdominal complaints, a high number of bowel movements a day, surgical interventions, and their consequences are very demanding somatically and psychologically. The social integration of patients, their quality of life, and their daily routine activities may often be difficult.

Limited data are available on quality of life after surgical treatment of UC. Incidence of the disease is increasing, and performing IPAA after a proctocolectomy has become the gold standard intervention in surgical treatment. ${ }^{16-18}$ It is a safe technique with low mortality and morbidity. ${ }^{19}$ Our Department was the first in Hungary to examine the minimally invasive technique in the treatment of UC. This method was successful in elective and acute cases as well. Moreover, the occurrence of complications was low compared with the open technique ${ }^{8,9}$ After successful surgical interventions, quality of life improved continuously, and pouchitis was considered the main problem. ${ }^{4}$

Patients having undergone a surgical intervention between January 1, 2005 and March 1, 2016 due to UC were enrolled in our study. Quality of life was examined with questionnaires considering gastroenterological and psychological conditions and daily activities. Results were analyzed in the laparoscopic group and in patients undergoing open surgery, in patients with or without a stoma, in the case of acute and elective interventions, and with regard to early and late complications. The average duration of the follow-up was 46 months.

In terms of disease representation, $92.3 \%$ of our patients considered their disease to be caused by psychological factors, $42.3 \%$ thought that genetic factors lay behind the disease, and $46.2 \%$ felt that environmental hazards were to blame. In conclusion, patients with UC are well informed and are aware of the nature and characteristics of their disease.

The consequences of wearing a stoma were examined as well. It showed a significant correlation with the BIPQ personal control subscale, meaning that patients with a stoma felt they had less control over their condition. Therefore, the presence of an anus prae, either temporary or permanent, was psychologically demanding for the patients; it made healing and daily activities more difficult. In addition to these results, no difference was found in quality of life among patients living with an ileostoma or a pouch in a prospective crosssectional observational study. ${ }^{20}$
Quality of life was examined with regard to laparoscopic surgery and open surgery as well. An examination of psychological differences between the two groups showed that trait anxiety was significantly different; that is, patients undergoing open surgery were more anxious. Based on the total score on the gastroenterological questionnaires, there was no difference between the two surgical methods, abdominal pain was more favorable in the laparoscopic group based on the functional scoring system, the SIBDQ and GIQLI. An Irish and a German study with a 10-year followup found a favorable quality of life after IPAA surgery, ${ }^{21,22}$ and an Indian study concluded that the IPAA was a suitable procedure with regard to functionality and quality of life. ${ }^{23}$ Nutritional difficulties, bowel movement problems, and daily and night-time incontinence were noted in both groups. Incontinence, increased number of bowel movements at night, and urgency were determined to be negative prognostic factors of quality of life in the literature. ${ }^{24}$ Our patients reported $>5$ stools during the day and $>1$ stool at night weekly in the postoperative period. Fichera et al. observed high rates of continence and an average of six bowel movements a day after laparoscopic IPAA. ${ }^{25}$ Polle et al. detected no difference in quality of life, functionality, and morbidity between the groups. ${ }^{26}$ Pouchitis was reported in $17(35.41 \%)$ cases, and cuffitis occurred in $13(27.08 \%)$ cases. According to a metaanalysis, there was no difference between the two surgical methods with regard to the number of bowel movements a day and pouchitis, ${ }^{27}$ while a Swedish study described longterm problems regarding pouchitis. ${ }^{28}$ Several other studies noted good quality of life after proctocolectomy. ${ }^{29-31}$

No difference was found between the two groups with regard to early complications. Late complications occurred significantly more often with emergency and open surgeries. With regard to the psychological factors, the values for the BIPQ personal control and coherence subscales were higher in patients with no late complications, meaning that they felt they had more control over their disease. A significant correlation was found between the results of the psychological

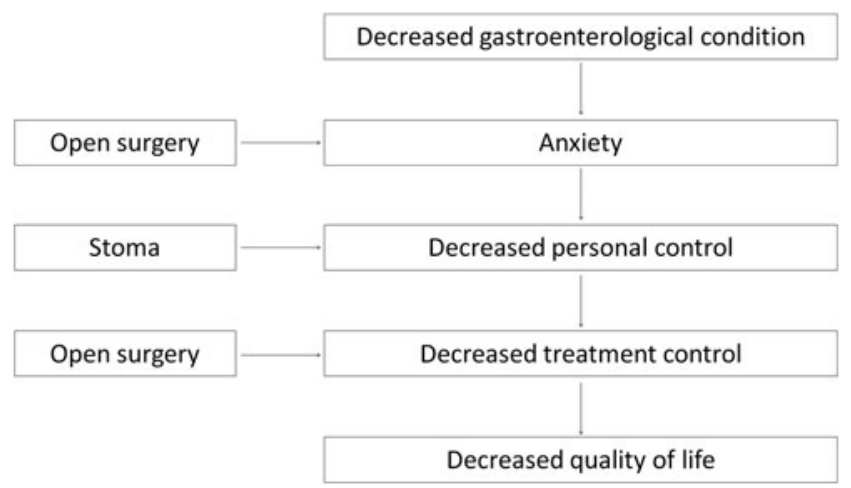

FIG. 2. Effect of gastroenterological and psychological conditions and surgical technique on quality of life. Deterioration of gastroenterological condition shows connection with decreased psychological status; anxiety, reduced personal and treatment control are more frequent. Furthermore, psychological condition is negatively influenced by the use of open surgical technique and the presence of a stoma. All these factors result in decreased quality of life. 
and gastrointestinal questionnaires. Consequently, a negative emotional condition and mood resulted in lower quality of life. Moreover, more anxious and depressed patients had a negative idea of their disease and less faith in the success of surgical interventions (Fig. 2).

An IBD study reported that psychological symptoms have a significant effect on the primary disease and that anxiety increases and social function deteriorates in correlation with the severity of the disease. In addition, it was shown that patients with more control over their disease enjoy a better gastroenterological condition. ${ }^{32}$

\section{Conclusion}

Our study is the first to examine quality of life among patients operated on for UC with regard to psychological and gastroenterological conditions. As a result, it can be concluded that a minimally invasive technique provides a better long-term outcome for patients with UC, fewer complications, and a more balanced emotional condition. Patients who undergo surgery with the standard method have a greater psychological burden and a negative image of their disease. Our study confirmed that a better gastroenterological condition gives rise to a better psychological condition. These factors result in a better quality of life for patients. Successful treatment of UC should be performed in centers with close gastroenterological and surgical cooperation. Psychological guidance is essential; thus, psychologists and social workers may have to be involved in the treatment of these patients.

\section{Disclosure Statement}

No competing financial interests exist.

\section{References}

1. Vegh Z, Burisch J, Pedersen N, et al. Incidence and initial disease course of inflammatory bowel diseases in 2011 in Europe and Australia: Results of the 2011 ECCO-EpiCom inception cohort. J Crohns Colitis 2014;8:1506-1515.

2. Bennis M, Tiret E. Surgical management of ulcerative colitis. Langenbecks Arch Surg 2012;397:11-17.

3. Dignass A, Lindsay JO, Sturm A, et al. Second European evidence-based consensus on the diagnosis and management of ulcerative colitis part 2: Current management. J Crohns Colitis 2012;6:991-1030.

4. Szepes Z, Molnar T, Farkas K, et al. [Better quality of life after surgery treatment in patients with colitis ulcerosa: What is the price]. Orv Hetil 2010;151:1264-1269.

5. Zoccali M, Fichera A. Minimally invasive approaches for the treatment of inflammatory bowel disease. World J Gastroenterol 2012;18:6756-6763.

6. Pellino G, Sciaudone G, Miele E, et al. Functional outcomes and quality of life after restorative proctocolectomy in paediatric patients: A case-control study. Gastroenterol Res Pract 2014;2014:340341.

7. Pica R, Cassieri C, Pronio AM, et al. Quality of life in ulcerative colitis patients treated medically versus patients undergoing surgery. Eur Rev Med Pharmacol Sci 2014;18: 693-698.
8. Tajti J, Jr., Simonka Z, Paszt A, et al. [Minimally invasive surgical treatment of ulcerative colitis-Long-term results]. Orv Hetil 2015;156:1585-1592.

9. Tajti J, Jr., Simonka Z, Paszt A, et al. Role of laparoscopic surgery in the treatment of ulcerative colitis; shortand mid-term results. Scand J Gastroenterol 2015;50: 406-412.

10. Oresland T, Fasth S, Nordgren S, et al. The clinical and functional outcome after restorative proctocolectomy. A prospective study in 100 patients. Int J Colorectal Dis 1989; 4:50-56.

11. Eypasch E, Williams JI, Wood-Dauphinee S, et al. Gastrointestinal Quality of Life Index: Development, validation and application of a new instrument. Br J Surg 1995;82: 216-222.

12. Guyatt G, Mitchell A, Irvine EJ, et al. A new measure of health status for clinical trials in inflammatory bowel disease. Gastroenterology 1989;96:804-810.

13. Beck AT, Ward $\mathrm{CH}$, Mendelson $\mathrm{M}$, et al. An inventory for measuring depression. Arch Gen Psychiatry 1961;4:561571.

14. Spielberger CD, Gorsuch RL, Lushene RE. Manual for the State-Trait Anxiety Inventory. Palo Alto: Consulting Psychologists Press, 1970.

15. Broadbent E, Petrie KJ, Main J, et al. The brief illness perception questionnaire. J Psychosom Res 2006;60:631637.

16. Hata K, Kazama S, Nozawa H, et al. Laparoscopic surgery for ulcerative colitis: A review of the literature. Surg Today 2015;45:933-938.

17. Kovács Á, Lakatos L. Inflammatory Bowel Diseases [In Hungarian]. Budapest, Hungary, Medicina, 2011, pp. 292-301.

18. Miheller P, Nagy F, Palatka K, et al. [Hungarian data on inflammatory bowel diseases: Analytical data on ulcerative colistis]. Orv Hetil 2012;153:702-712.

19. Ikeuchi H, Uchino M, Matsuoka H, et al. Surgery for ulcerative colitis in 1,000 patients. Int J Colorectal Dis 2010; 25:959-965.

20. Kuruvilla K, Osler T, Hyman NH. A comparison of the quality of life of ulcerative colitis patients after IPAA vs ileostomy. Dis Colon Rectum 2012;55:1131-1137.

21. Leowardi C, Hinz U, Tariverdian M, et al. Long-term outcome 10 years or more after restorative proctocolectomy and ileal pouch-anal anastomosis in patients with ulcerative colitis. Langenbecks Arch Surg 2010;395:49-56.

22. Browne C, Shaikh F, Iqbal N, et al. Quality of life, continence and frequency of pouchitis following laparoscopic versus open colectomy and ileal pouch-anal anastomosis: An Irish perspective. Ir J Med Sci 2015;184:655-658.

23. Raviram S, Rajan R, Sindhu RS, et al. Quality of life, social impact and functional outcome following ileal pouch-anal anastomosis for ulcerative colitis and familial adenomatous polyposis. Indian J Gastroenterol 2015;34:252-255.

24. Andersson T, Lunde OC, Johnson E, et al. Long-term functional outcome and quality of life after restorative proctocolectomy with ileo-anal anastomosis for colitis. Colorectal Dis 2011;13:431-437.

25. Fichera A, Silvestri MT, Hurst RD, et al. Laparoscopic restorative proctocolectomy with ileal pouch anal anastomosis: A comparative observational study on longterm functional results. J Gastrointest Surg 2009;13: 526-532.

26. Polle SW, Dunker MS, Slors JF, et al. Body image, cosmesis, quality of life, and functional outcome of hand-assisted 
laparoscopic versus open restorative proctocolectomy: Longterm results of a randomized trial. Surg Endosc 2007;21: 1301-1307.

27. Singh P, Bhangu A, Nicholls RJ, et al. A systematic review and meta-analysis of laparoscopic vs open restorative proctocolectomy. Colorectal Dis 2013;15:e340-e351.

28. Karlbom U, Lindfors A, Pahlman L. Long-term functional outcome after restorative proctocolectomy in patients with ulcerative colitis. Colorectal Dis 2012;14:977-984.

29. Brandsborg S, Tottrup A, Nicholls J, et al. Restorative proctocolectomy in patients with ulcerative colitis: A crosssectional Danish population study on function and quality of life. Colorectal Dis 2013;15:e453-e461.

30. Larson DW, Davies MM, Dozois EJ, et al. Sexual function, body image, and quality of life after laparoscopic and open ileal pouch-anal anastomosis. Dis Colon Rectum 2008;51: 392-396.
31. Heikens JT, de Vries J, Goos MR, et al. Quality of life and health status before and after ileal pouch-anal anastomosis for ulcerative colitis. Br J Surg 2012;99:263-269.

32. Rochelle TL, Fidler H. The importance of illness perceptions, quality of life and psychological status in patients with ulcerative colitis and Crohn's disease. J Health Psychol 2013;18:972-983.

Address correspondence to: György Lázár, $M D, P h D, D S c$ Department of Surgery University of Szeged Semmelweis Street 8 Szeged H-6725 Hungary

E-mail: lazar.gyorgy@med.u-szeged.hu 



\title{
(Q) EREDETI KÖZLEMÉNY
}

\author{
TENZIÓS TÍPUSÚ FEJFÁJÁS ÉS COLITIS ULCEROSA \\ TAJTI Jr. János, LÁTOS Melinda, ÁBRAHÁM Szabolcs, SIMONKA Zsolt, PASZT Attila, LÁZÁR György \\ Szegedi Tudományegyetem, Általános Orvostudományi Kar, Sebészeti Klinika, Szeged
}

Célkitúzés - A tenziós típusú fejfáiás igen gyakori, az átlagpopulációban az élettartam-prevalenciája 30-78\%, így meglehetősen magas a társadalmi-gazdasági hatása. A gyulladásos bélbetegségek incidenciája folyamatosan emelkedik. Magyarországon colitis ulcerosa miatt mútéttel kapcsolatos életminőségi adatokkal eddig limitált számban rendelkeztünk. Jelen tanulmányunkban a colitis ulcerosa miatt mútéten átesett betegpopuláció életminőségét vizsgáltuk a fejfájás vonatkozásában.

Módszerek - 2005. január 1. és 2016. március 1. közöHt 75 betegnél végeztünk colitis ulcerosa miatt mútétet. Retrospektív módszerrel végzett utánkövetésünk átlagosan 46 (1-124) hónapig tartott, mely során a Rövid Betegségpercepció Kérdőívet és a Fejfájás Kérdőívet felhasználva regisztráltuk a fejfájás megjelenését.

Eredmények - Az elsődleges fejfáiásbetegségek $(n=27)$ közül 19 (70,4\%) beteg tenziós típusú fejfájásban, 8 $(29,6 \%)$ beteg migrénben (aura nélküli) szenvedett. A tenziós típusú fejfájásos betegek közül 17 (89,5\%) epizodikus, $2(10,5 \%)$ krónikus formába tartozott. A fejfájástól szenvedő betegek szignifikánsan magasabb pontszámot értek el a Rövid Betegségpercepció Kérdő'iven.

Következtetések - Felmérésünk szerint a tenziós típusú fejfáiás a colitis ulcerosában szenvedő betegek között gyakori. Ez felveti a két kórforma között a stressznek mint kóroki tényezónek a szerepét, mely nagymértékben befolyásolja és rontja a betegek életminőségét. A fentiek alapián megfontolandó a colitis ulcerosában szenvedő populáció neurológiai kivizsgálása, szükség szerint pszichiátriai, pszichológiai gondozása.

Kulcsszavak: tenziós típusú fejfájás, colitis ulcerosa, mútét, életminőség
TENSION-TYPE HEADACHE IN ULCERATIVE COLITIS

Tajit Jr. J, MD; Látos M, PhD; Ábrahám Sz, MD, PhD;

Simonka Zs, MD, PhD; Paszł A, MD, PhD;

Lázár Gy, MD, PhD, DSc

Ideggyogy Sz 2017;70(10-11):389-393.

Background and purpose - Tension-type headache is a very common disease with a high socio-economic impact as its lifetime prevalence is $30-78 \%$ in the general population. The incidence of inflammatory bowel diseases is continuously rising. Limited data are accessible on quality of life in patients with surgically treated ulcerative colitis. The aim of our study is to examine quality of life, concerning headache, among patients who had undergone surgery due to ulcerative colitis.

Methods - Between 1 January 2005 and 1 March 2016, surgery was performed due to ulcerative colitis in 75 patients. During this retrospective analysis the average duration of the follow-up was $46(1-124)$ months. The presence of headache was evaluated by the use of Brief Illness Perception and Headache Questionnaires.

Results - Among the primary headache disorders $(n=27)$, tension-type headache occurred in $19(70.4 \%)$ cases, and 8 (29.6\%) patients had migraine (without aura). Among tension-type headache cases 17 (89.5\%) patients experienced episodic form and 2 (10.5\%) suffered from chronic form. Patients with headache had obtained a significantly higher score on Brief Illness Perception Questionnaire. Conclusions - According to our study tension-type headache is common among patients with ulcerative colitis. This observation raises the question whether stress plays role in the pathogenesis of both diseases, which influences and worsens considerably quality of life. Neurological examination, psychological and psychiatric guidance are worth considering in patients with ulcerative colitis.

Keywords: tension-type headache, ulcerative colitis, surgery, quality of life

Levelező szerző (correspondent): Prof. dr. LÁZÁR György, Szegedi Tudományegyetem, Általános Orvostudományi Kar, Sebészeti Klinika; 6720 Szeged, Semmelweis u. 8. E-mail: gylazar@gmail.com

http://orcid.org/0000-0001-7155-2978

Érkezett: 2017. szeptember 2. Elfogadva: 2017. október 5. 
$\mathrm{A}^{\mathrm{N}}$ Nemzetközi Fejfájás Társaság klasszifikációja alapján a fejfájásbetegségek lehetnek elsődleges vagy másodlagos típusúak. Az elsődleges fejfájások közé soroljuk a migrént, a tenziós típusú fejfájást, a trigeminalis autonóm cephalalgiákat, valamint az egyéb primer fejfájásbetegségeket ${ }^{1}$. A tenziós típusú fejfájás igen gyakori, az átlagpopulációban az élettartam-prevalenciája 30-78\%, így meglehetősen magas a társadalmi-gazdasági hatása. Jellegzetessége a kétoldali nyomó, szorító (nem lüktető) fájdalom, mely közepes vagy enyhe intenzitású, 30 perctôl akár hét napig is tart. A fájdalmat nem befolyásolja a rutin fizikai aktivitás. Nem társul hozzá hányinger vagy hányás, de fotofóbia vagy fonofóbia kísérheti. Járhat a pericranialis izmok érzékenységével, vagy a nélkül. A fokozott pericranialis nyomásérzékenység típusosan interictalisan jelentkezik, és mértéke fokozódik a fejfájások intenzitásával és gyakoriságával ${ }^{1}$. A tenziós típusú fejfájásnak két fó formája van: az epizodikus (ritka vagy gyakori) és a krónikus. A krónikus tenziós típusú fejfájásra jellemző, hogy egy hónapban 15-nél több fejfájásnap van, legalább egymást követő három hónapon át. A krónikus forma egy súlyos betegség, amely jelentősen rontja az életminőséget és rokkantsághoz vezet. A tenziós típusú fejfájás pontos patomechanizmusa mindmáig ismeretlen, habár a perifériás fájdalommechanizmusok szerepet játszanak az epizodikus forma, míg a centrális fájdalommechanizmusok a krónikus forma kialakulásában.

A gyulladásos bélbetegségek (IBD) megjelenése folyamatosan emelkedik, magyarországi incidenciáját napjainkban 24/100 000-re becsülik ${ }^{2}$. A betegségnek két fó formája ismert: az egész tápcsatornát érintő Crohn-betegség, valamint a vastagbélre lokalizálódó colitis ulcerosa (CU). Az IBD patogenezise nem teljesen tisztázott, a kórkép kialakulásában környezeti, genetikai és immunológiai hatásokat, interakciókat feltételeznek. A CU kialakulásában szerepet játszik az urbanizáció, a ,nyugatias” életmód elterjedése, valamint a gyakori stresszes életmód, pszichés tényezők ${ }^{3,4}$. Kezelésük elsődlegesen gyógyszeres, azonban annak sikertelensége esetén, illetve a betegség szövődményes eseteiben mútéti beavatkozás válik szükségessés.

A CU sebészi kezelésében a leginkább elfogadott mútéti megoldás a célszerv (a teljes vastagbéltraktus) eltávolításával járó proctocolectomia. A rekonstrukció során a tápcsatorna folytonosságát a terminális ileumból képzett ileoanalis ,„pouch”-csal állítják helyre. A beavatkozásnak hagyományos és laparoszkópos módszere ismert ${ }^{5}$, melyek célja az életminőség hosszú távú javítása ${ }^{6,7}$. Az életminőséget tekintve a sebészi kezelés előnye igazolódott a gyógyszeresen kezelt betegekkel szemben ${ }^{8}$.
Magyarországon CU miatt mútéttel kapcsolatos életminőségi adatokkal eddig korlátozott számban rendelkeztünk. Hazánkban elsőként számolunk be a CU miatt mútéti beavatkozást követő közép- és hosszú távú klinikai eredményekről ${ }^{9,10}$.

Jelen tanulmányunkban a CU és különböző mútéti technikákat követő életminőséget érintő tényezők közül a fejfájás megjelenését vizsgáltuk.

\section{Beteganyag és módszer}

2005. január 1. és 2016. március 1. között 75 betegnél végeztünk CU miatt mútétet, melyek közül nyitott módon 25, minimálinvazív technikával 50 beavatkozás történt. Az 58 beteg közül (29 nô, 29 férfi) 41-ben laparoszkópos, 17-ben nyitott mútétre került sor. Vizsgálatunk ideje alatt 17 beteg bélelőhelyezéssel (stoma) élt.

A jelen klinikai vizsgálat a Szegedi Tudományegyetem Etikai Bizottsága által jóváhagyott módon zajlott (194/2015-SZTE). A 75 mútött beteg közül 58 esetben tudtuk kérdőíves vizsgálatunkat elvégezni. Utánkövetésünk átlagosan 46 (1-124) hónapig tartott.

\section{KÉRDÖÍVEK}

\section{Rövid Betegségpercepció Kérdöív}

A betegségreprezentációkat és a gyógyulással kapcsolatos attitúdöket a Rövid Betegségpercepció Kérdőívvel vizsgáltuk, mely nyolc alskálát (Hatás, Időtartam, Személyes kontroll, Kezelési kontroll, Tünetek identitása, Aggódás, Koherencia és Érzelmi reprezentáció) tartalmazott ${ }^{11}$.

\section{Fejfájás Kérdöiv}

A betegek fejfájásának jellegét az általunk összeállított 16 kérdéses Fejfájás Kérdőívvel mértük fel. A kérdések a fájdalom gyakoriságát, oldaliságát, lokalizációját, jellegét, erôsségét, időtartamát, a kísérő tünetek megjelenését, a betegek fejfájásukról alkotott véleményét, az alkalmazott terápiát, annak hatékonyságát, valamint az életvezetésre gyakorolt hatását célozták meg, a Nemzetközi Fejájás Klasszifikáció 3beta verziójának kritériumrendszere alapján ${ }^{1}$.

\section{STATISZTIKA}

A betegek adatait retrospektív módszerrel tekintettük át. A statisztikai feldolgozást SPSS programmal (IBM SPSS Statistics, Version 20.0 2014, Chicago, IL, USA) végeztük. A változók közötti kapcsolatok feltárására Pearson- és Spearman-korrelációt hasz- 
náltunk. A csoportok összehasonlításánál független t-próbát, Mann-Whitney-próbát, ANOVA-t és $\chi^{2}$ próbát alkalmaztunk. Statisztikailag szignifikánsnak tekintettük, ahol a p-érték kisebb volt, mint 0,05 .

\section{Eredmények}

A Nemzetközi Fejfájás Klasszifikáció 3beta verziójának kritériumrendszerét figyelembe véve osztályoztuk a betegek fejfájását ${ }^{1}$. Ezek alapján 43 $(74,1 \%)$ beteg jelzett fejfájást, amelyek közül 27 (62,8\%) elsődleges és 16 (37,2\%) másodlagos, azaz szimptómás fejfájás volt (1. ábra). Az elsôdleges $(n=27)$ fejfájások közül $19(70,4 \%)$ beteg tenziós típusú fejfájásban, $8(29,6 \%)$ beteg aura nélküli migrénben szenvedett, míg a trigeminalis autonóm cephalalgiák csoportjába egy beteg sem tartozott ( 2 . ábra). A tenziós típusú fejfájásos betegek $(\mathrm{n}=19)$ közül 17 (89,5\%) epizodikus, 2 (10,5\%) krónikus formát mutatott (3. ábra). Az életminőséget és a napi életvitelt tekintve a betegek 79,1\%-át (n=34) enyheközepes mértékben zavarja fejfájása. Fejfájás megjelenésében nincs különbség a laparoszkópos és nyitott módszerrel operált, valamint a stomát viselő vagy nem viselő betegek esetében. A fejfájástól szenvedő betegek szignifikánsan magasabb pontszámot értek el a Rövid Betegségpercepció Kérdőíven a fejfájást nem panaszolókhoz viszonyítva $(\mathrm{p}=0,036$; Pearsonés Spearman-korreláció $=-0,33$ ).

\section{Megbeszélés}

Jelen tanulmányunk Magyarországon elsóként vizsgálja a CU miatt sebészi kezelésben részesülő betegek körében a fejfájás megjelenését. Eredményeink alapján a CU miatt operált személyekben fejfájást tekintve a tenziós típusú fejfájás jelent meg leggyakrabban, mint elsődleges fejfájásforma. Életminőségüket enyhe-közepes mértékben zavarta a napi életvitelük során. A Rövid Betegségpercepció Kérdőív eredményei alapján az alapbetegséggel járó rosszabb hangulati állapotot a fejfájás tovább rontotta. A tenziós típusú fejfájás kialakulásában elsődleges szerepet tulajdonítanak a stressznek és a pszichés feszülésnek ${ }^{12,13}$. Ezenfelül a krónikus tenziós típusú fejfájás megjelenése nagymértékben függ a napi lelki traumák gyakoriságától, súlyosságától, valamint az anxietastól ${ }^{14}$. A tenziós típusú fejfájásban szenvedó betegek nehezebben tudják az emóciójukat kifejezni és a maladaptív „coping” is gyakoribb $^{12,15}$. A tenziós típusú fejfájás negatívan befolyásolja az életminőséget ${ }^{16}$.

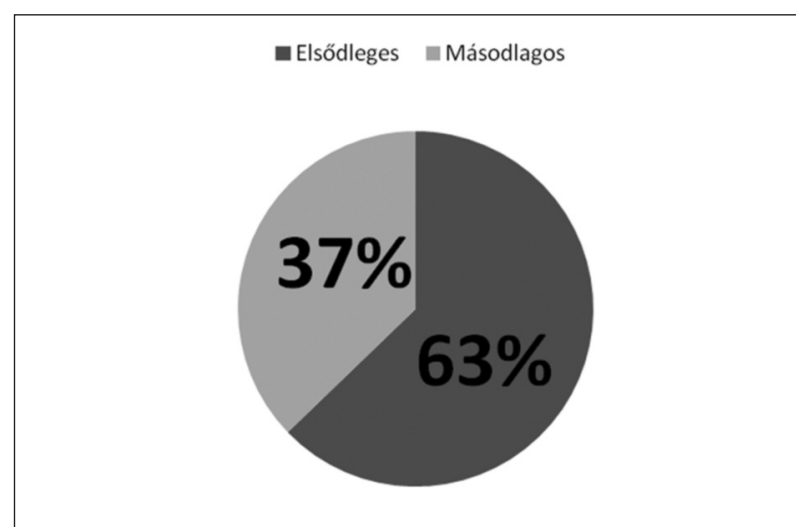

1. ábra. Elsődleges és másodlagos fejfájások megoszlása a mütött colitis ulcerosás betegek körében

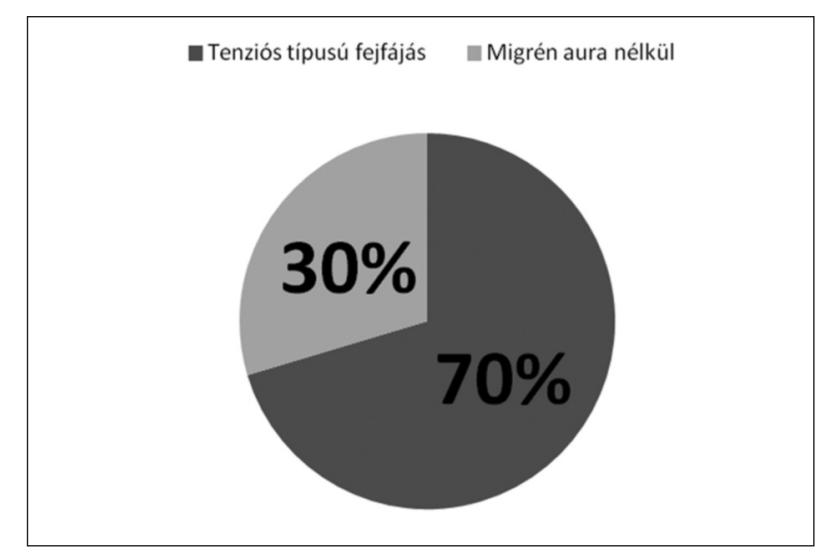

2. ábra. Elsődleges fejfájástípusok megoszlása a mütött colitis ulcerosás betegek körében

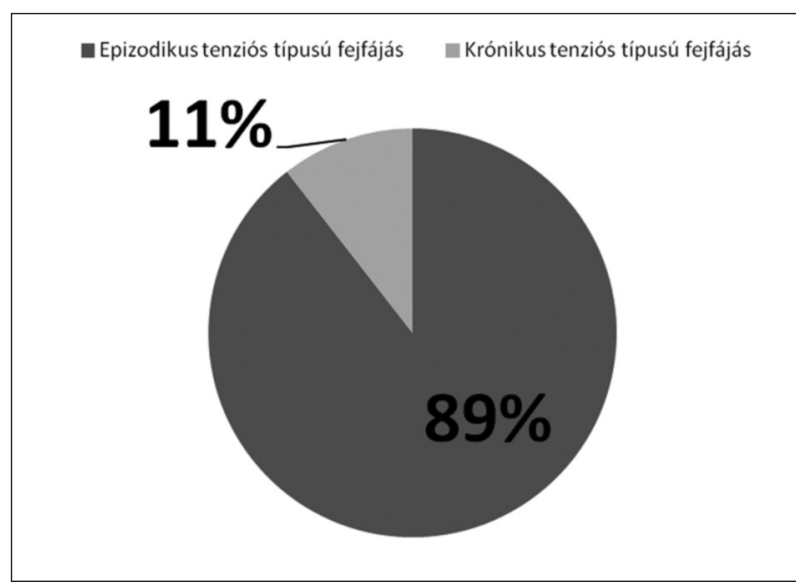

3. ábra. Tenziós típusú fejfájásformák megoszlása a mútött colitis ulcerosás betegek körében

Széles körú vizsgálatok alapján igazolást nyert, hogy IBD-ben, így CU-ban szenvedő betegeknél az anxietas és a depresszió igen magas prevalenciával fordul elő ${ }^{17}$. Továbbá igazolt az is, hogy visszatéró vagy elhúzódó stresszel járó események az IBD fel- 
lángolását idézik elő̉. Állatkísérletes megfigyelések a környezeti tényezők stresszként történő megváltozását a CU-szerú colitis oki tényezôjének írták $l^{18}$. Humán megfigyelések alapján a táplálkozás, bizonyos gyógyszeres kezelés (antibiotikumok, D-vitamin, ösztrogéntartalmú hormonális fogamzásgátlók, nem szteroid gyulladásgátlók) rizikótényezônek számít a CU megjelenésében és gyakori kiújulásában ${ }^{19,20}$. Kiemelendő, hogy az antioxidánsok táplálékkal történő bevitele kedvező hatást mutatott ${ }^{21}$, míg a nyugat-európai életstílussal járó táplálkozási szokások kártékonyak az IBD vonatkozásában ${ }^{22}$. A stressz feltételezhetôen a hypothalamus-hypophysis-mellékvese tengelyen, az autonóm idegrendszer bevonásával játszik szerepet az IBD patogenezisében. Erre utal az is, hogy az emocionális megbetegedések incidenciája kiemelkedôen magas CU-ban az átlagpopulációhoz viszonyítva. Ezenfelül az anxietas és a depresszió foka kifejezetten befolyásolja a CU súlyosságát ${ }^{23}$. A neuropeptidek, elsósorban a P-anyag (SP) szerepére a CU

\section{IRODALOM}

1. Headache Classification Committee of the International Headache S. The International Classification of Headache Disorders, 3rd edition (beta version). Cephalalgia 2013;33: 629-808. https://doi.org/10.1177/0333102413485658

2. Vegh Z, Burisch J, Pedersen N, Kaimakliotis I, Duricova $D$, Bortlik M, et al. Incidence and initial disease course of inflammatory bowel diseases in 2011 in Europe and Australia: results of the 2011 ECCO-EpiCom inception cohort. J Crohns Colitis 2014;8:1506-15. https://doi.org/10.1016/j.crohns.2014.06.004

3. Kovács Á, Lakatos L. Gyulladásos bélbetegségek. Medicina; 2011.

4. Shouval DS, Rufo PA. The Role of Environmental Factors in the Pathogenesis of Inflammatory Bowel Diseases: A Review. JAMA Pediatr 2017. https://doi.org/10.1001/jamapediatrics.2017.2571

5. Bennis $M$, Tiret $E$. Surgical management of ulcerative colitis. Langenbecks Arch Surg 2012;397:11-7. https://doi.org/10.1007/s00423-011-0848-x

6. Dignass A, Lindsay JO, Sturm A, Windsor A, Colombel JF, Allez $M$, et al. Second European evidence-based consensus on the diagnosis and management of ulcerative colitis part 2: current management. J Crohns Colitis 2012;6:991-1030. https://doi.org/10.1016/j.crohns.2012.09.002

7. Szepes Z, Molnar T, Farkas K, Horvath G, Nagy F, Nyari $T$, et al. Better quality of life after surgery treatment in patients with colitis ulcerosa: what is the price. Orv Hetil 2010;151:1264-9. https://doi.org/10.1556/OH.2010.28908

8. Pica R, Cassieri C, Pronio AM, Zippi M, Avallone EV, Montesani $C$, et al. Quality of life in ulcerative colitis pati- kialakulásában kísérletes bizonyítékok utalnak. Az SP a tachykininek csoportjába tartozik, receptora a neurokinin 1 (NK1). Megfigyelések alapján NK1receptor-antagonisták a colitises tüneteket jelentősen mérséklik ${ }^{24}$.

\section{Megbeszélés}

Felmérésünk szerint a tenziós típusú fejfájás a CUban szenvedó betegek között gyakori. Ez felveti a két kórforma között a stressznek mint kóroki tényezőnek a szerepét, mely nagymértékben befolyásolja és rontja a betegek életminőségét. A fentiek alapján megfontolandó a CU-ban szenvedó populáció neurológiai kivizsgálása, szükség szerint pszichiátriai, pszichológiai gondozása.

\section{KÖSZÖNETNYILVÁNÍTÁS}

Köszönjük dr. Csáti Anettnek hasznos és kritikus tanácsait. ents treated medically versus patients undergoing surgery. Eur Rev Med Pharmacol Sci 2014;18:693-8.

9. Tajti J, Jr., Simonka Z, Paszt A, Abraham S, Farkas $K$, Szepes $Z$, et al. Minimally invasive surgical treatment of ulcerative colitis - long-term results. Orv Hetil 2015;156: 1585-92. https://doi.org/10.1556/650.2015.30262

10. Tajti J, Jr., Simonka Z, Paszt A, Abraham S, Farkas K, Szepes $Z$, et al. Role of laparoscopic surgery in the treatment of ulcerative colitis; short- and mid-term results. Scand J Gastroenterol 2015;50:406-12. https://doi.org/10.3109/00365521.2014.985705

11. Broadbent E, Petrie KJ, Main J, Weinman J. The brief illness perception questionnaire. J Psychosom Res 2006;60: 631-7. https://doi.org/10.1016/j.jpsychores.2005.10.020

12. Torelli P, Abrignani G, Castellini P, Lambru G, Manzoni $G C$. Human psyche and headache: tension-type headache. Neurol Sci 2008;29 Suppl 1:S93-5. https://doi.org/10.1007/s10072-008-0896-3

13. Clark GT, Sakai S, Merrill R, Flack VF, McCreary $C$. Cross-correlation between stress, pain, physical activity, and temporalis muscle EMG in tension-type headache. Cephalalgia 1995;15:511-8, discussion 451 .

14. De Benedittis $G$, Lorenzetti A. Minor stressful life events (daily hassles) in chronic primary headache: relationship with MMPI personality patterns. Headache 1992;32:330-4.

15. Heckman BD, Holroyd KA. Tension-type headache and psychiatric comorbidity. Curr Pain Headache Rep 2006; 10:439-47.

16. Risal A, Manandhar K, Holen A, Steiner TJ, Linde M. Comorbidities of psychiatric and headache disorders in 
Nepal: implications from a nationwide population-based study. J Headache Pain 2016;17:45.

https://doi.org/10.1186/s10194-016-0635-8

17. Tarricone I, Regazzi MG, Bonucci G, Rizzello $F$, Carini $G$, Muratori $R$, et al. Prevalence and effectiveness of psychiatric treatments for patients with IBD: A systematic literature review. J Psychosom Res 2017;101:68-95. https://doi.org/10.1016/j.jpsychores.2017.07.001

18. Collins SM. Stress and the Gastrointestinal Tract IV. Modulation of intestinal inflammation by stress: basic mechanisms and clinical relevance. Am J Physiol Gastrointest Liver Physiol 2001;280:G315-8.

19. Burke KE, Boumitri C, Ananthakrishnan AN. Modifiable Environmental Factors in Inflammatory Bowel Disease. Curr Gastroenterol Rep 2017;19:21. https://doi.org/10.1007/s11894-017-0562-0

20. Martin TD, Chan SS, Hart AR. Environmental factors in the relapse and recurrence of inflammatory bowel disease: a review of the literature. Dig Dis Sci 2015;60:1396405.

https://doi.org/10.1007/s10620-014-3437-3

21. Khan I, Samson SE, Grover AK. Antioxidant Supplements and Gastrointestinal Diseases: A Critical Appraisal. Med Princ Pract 2017;26:201-17. https://doi.org/10.1159/000468988

22. Ye Y, Pang Z, Chen W, Ju S, Zhou C. The epidemiology and risk factors of inflammatory bowel disease. Int J Clin Exp Med 2015;8:22529-42.

23. Sgambato D, Miranda A, Ranaldo R, Federico A, Romano $M$. The Role of Stress in Inflammatory Bowel Diseases. Curr Pharm Des 2017.

https://doi.org/10.2174/1381612823666170228123357

24. Danese S, Sans M, Fiocchi C. Inflammatory bowel disease: the role of environmental factors. Autoimmun Rev 2004;3:394-400.

https://doi.org/10.1016/j.autrev.2004.03.002

\section{ERRATUM}

Az Ideggyógyászati Szemle 2017. július 29-én megjelent 7-8. összevont számában a 279. oldalon található $2 \mathrm{~A}$ ábra ábraaláíása hibásan jelent meg. A RÁCZ Lilla, BERÉNYI Ervin, BARSI Péter, BERNÁTH Dávid, CSÉPÁNY Tünde: Elönyös a másodvonalbeli immunmoduláns kezelés sclerosis multiplexben? címü közlemény [Ideggyogy Sz 2017;70(7-8):275-283.] 2A ábra ábraaláírása helyesen (a javított szövegrész félkövérrel jelölve): Azathioprin és intramuscularis interferon- $\beta 1$ a mellett is aktív állapotot követően négy évig, a terhesség kialakulásáig alkalmazott natalizumabkezelés mellett a betegséget aktivitásmentes állapot jellemzi. 